A Dissertation

Presented to

The Faculty of the Graduate School

At the University of Missouri

In Partial Fulfillment

Of the Requirements for the Degree

Doctor of Philosophy

By

KRISHNA LAL POUDEL

Dr. Thomas G. Johnson, Dissertation Supervisor

DECEMBER 2017 
The undersigned, appointed by the dean of the Graduate School, have examined the Dissertation entitled THREE ESSAYS ON ECONOMICS OF WATER RESOURCES MANAGEMENT IN NEPAL

Presented by KRISHNA LAL POUDEL

A candidate for the degree of

Doctor of Philosophy

And hereby certify that, in their opinion, it is worthy of acceptance.

Professor Thomas G. Johnson

Professor Judith I. Stallmann

Professor Corinne Valdivia

Professor Francisco X. Aguilar 


\section{ACKNOWLEDGEMENTS}

This is indeed a very elating moment for me to earn a doctoral degree from University of Missouri (MU). This elation was realized because of the constant support of my family, faculties, staffs and friends.

I heartily express my deepest sense of gratitude and profound appreciations to Professor Thomas G. Johnson, dissertation supervisor for his entire effort in shaping me as successful graduate student at this University. I am highly indebted for his continuous guidance, encouragement and support throughout this doctoral research proposal development, field visit, primary data collection and final manuscript preparation. He has helped me immeasurably in my professional socialization, has always provided me the opportunity to interact with professionals and has always been a strong advocate for me.

I highly acknowledge the help and guidance that I received from Professor Judith I. Stallmann, Professor Corinne Valdivia, and Professor Francisco X. Aguilar as my dissertation committee members. I Would like to appreciate the support that I received from Dr. Harvey James (Director of Graduate Studies, Department of Agriculture and Applied Economics). I wish to thank my senior colleagues Dr. Bhawani P. Mishra and Dr. Shriniwas Gautam for their constant motivation to conduct research in remote and rural regions of Nepal. I wish to thank my friends Mr. Harikrishna Poudel and Mr. Dinesh

Dhakl, both are PhD students in Public Affairs at MU for their moral support and family 
cooperation. My special acknowledgement is due to Dr. Ajit Joshi who first received and welcome me in Columbia.

I wish to express faithful gratitude to my parents for their heartfelt and never ending support and love. I am here with my beloved daughter Aditi who is ever asking me when do you graduate Dad? She has already made a congratulation card herself but not disclosed yet. She is the only sources of empowerment and motivation in doing successive academic progress. My beloved wife who is also defensing her dissertation and graduating this fall from the Department Plant Science deserves immense appreciation for her support despite her hectic schedules at her laboratory. 


\section{TABLE OF CONTENTS}

PAGE

ACKNOWLEDGEMENTS ..........................................................

LIST OF ILLUSTRATIONS .................................................vii

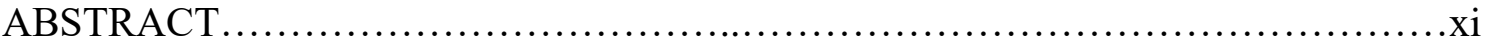

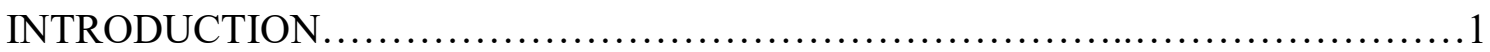

STUDY SITE, SAMPLING AND DATA........................................

ESSAY 1: Smallholder Farming Efficiency in Upriver-Downriver Ecoregions of the

Koshi River Basin in Nepal...................................................

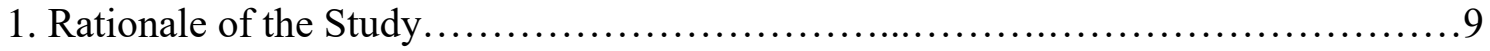

2. Literature Review.......................................................... 11

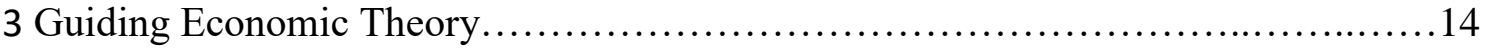

3.1. Technical, Allocative and Economic Efficiency..........................17

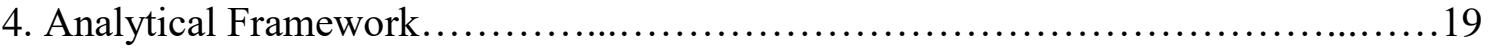

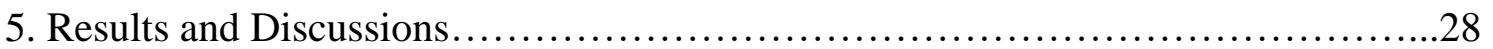

5.1. Descriptive Statistics...............................................28

5.2. Technical, Allocative, Cost and Scale Efficiency...........................29

5.3. Factors Affecting Technical Efficiency................................... 34

6. Essay Summary and Policy Recommendations.................................38

7. References............................................................... 40 
ESSAY 2: Determinants of Water Resource Adaptation in Nepal: a Logistic

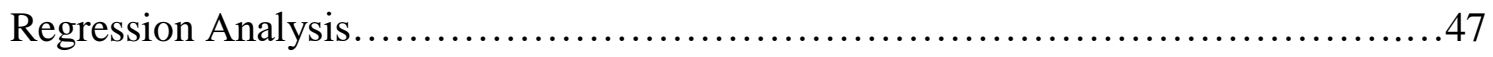

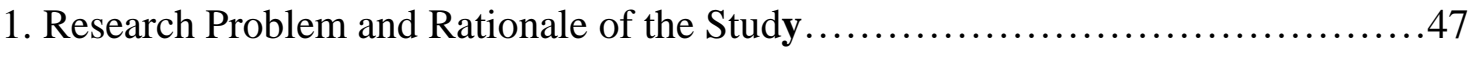

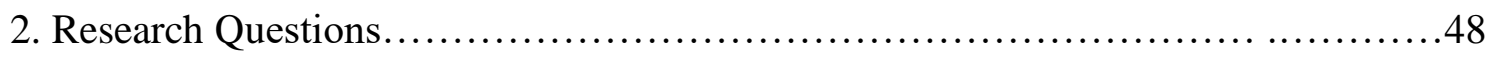

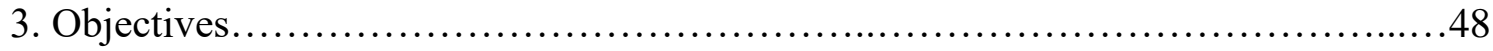

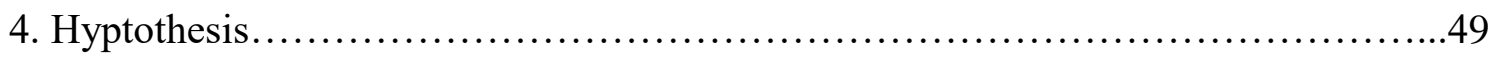

5. Literature Review......................................................... 49

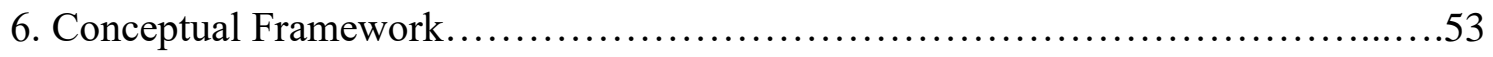

7. Analyzing Farmers' Adaptation Approach.......................................57

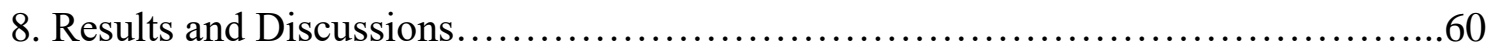

8.1. Descriptive Statistics...................................................60

8.2. Climate Change and Observed Changes in Precipitation, Wind and

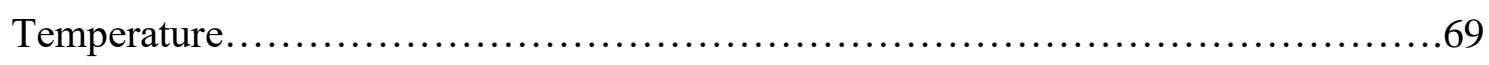

8.3. Water Level Change in Creeks/Rivulets.......................................71

8.4. Economic Impacts of Landslides and Floods.................................72

8.5. Climate Change Adaptation and Land Use Pattern Change.......................73

8.6. Institutional Involvement and Preferred Adaptation Approach......................76

8.7. Factors Affecting Adaptation Decision to Water Resources in Agriculture..........78

9. Essay Summary and Policy Recommendations................................... 81

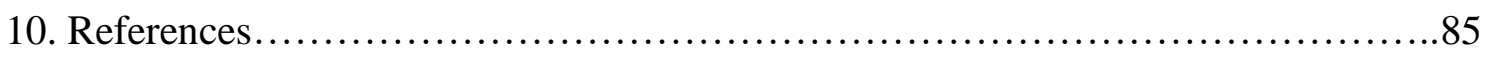


ESSAY 3: Water Use Efficiency and Its Determinants in Three Ecoregions of Nepal...95

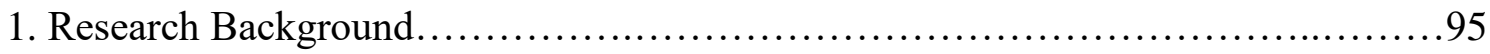

2. Research Problem and Rationale of the Study.................................97

3. Theoretical Framework................................................... 100

3.1. Irrigation Management............................................... 100

3.2. The Theory of Economic Rent......................................... 102

4. Analytical Approach.................................................. 104

5. Results and Discussions................................................ 106

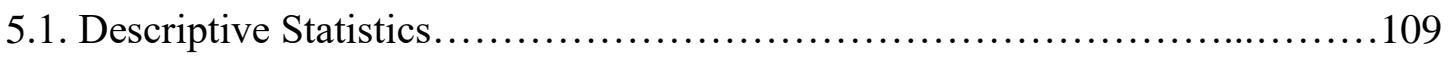

5.2. Factors Affecting Water Use Efficiency............................... 120

6. Eassy Summary and Policy Recommendations................................. 127

7. References......................................................... 126

SUMMARY, CONCLUSIONS AND POLICY IMPLICATIONS ...................135

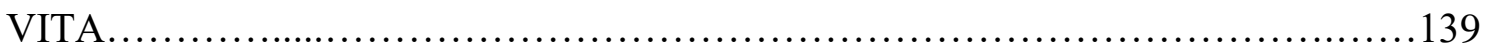




\section{LIST OF ILLUSTRATIONS}

Page

\section{Study Site, Sampling and Data Figure}

Figure 1: Ecological zones and study sites in Nepal.........................5

\section{Essay One Figures}

Figure 1: Farrell's efficiency indices........................................ 15

Figure 2: Technical, Allocative and Economic Efficiency................... 18

Figure 3: DEA simulated best practice frontier..........................20

Figure 4: Output produced in different categories of TE....................32

Figure 5: Output produced under different categories of AE..................33

Essay Ttwo Figure

Figure 1: Profit Maximization.........................................56

\section{Essay Three Figures}

Figure 1: Hypothesized effect of water on farm yield........................104

Figure 2: Average agricultural water consumption $\left(\mathrm{m}^{3} /\right.$ year $) \ldots \ldots \ldots \ldots \ldots \ldots 113$

Figure 3: Percentage distribution of irrigation status in the study areas........114

Figure 4: Average percentage of land cover under irrigation in three major seasons.......................................................... 114

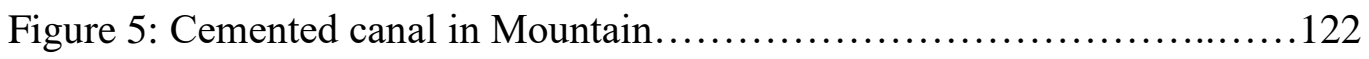

Figure 6: Rainwater collection plastic pond..............................122

Figure 7: Artesian water extraction for agricultural purpose in Terai..........123 


\section{Tables on Study Site, Sampling and Data}

Table 1. Climate charatcteristics of upriver and downriver regions.............4

Table 2. Climate chracteristics in three ecological belts of Nepal...............4

Tabl3 3. Variables definition and measurement.............................. 7

\section{Essay One Tables}

Table 1. Summary statistics of farm related variables in upriver-down river

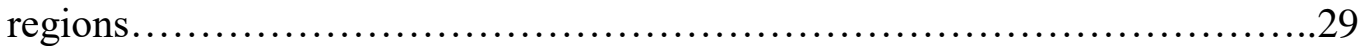

Table 2. Distribution of Technical Efficiency under CRS and VRS data envelopment analysis............................................... 31

Table 3. Distribution of farms according to return to scale....................31

Table 4. Allocative, Cost and Scale efficiency in upriver and downriver.........34

Table 5. Determinants of Technical inefficiency in upriver and downriver farming communities................................................. 35

\section{Essay Two Tables}

Table 1. Climate risks and adaptation measures to water resources............50

Table 2. Climate hazards statistics in Nepal (1971-2011)...................52

Table 3. Descriptive statistics of survey parameters for the study regions.......61

Table 4. Cropping intensity between the adaptive and non-adaptive

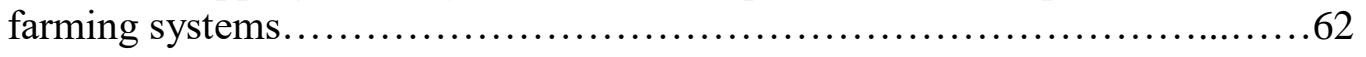

Table 5. Economic indicators (mean value) between non-adaptive and adaptive farming.

Table 6. Frequency distribution of respondent's perception of future water availability. 
Table 7. Feasible approaches to water resource management in the study regions............................................................68

Table 8. Frequency distribution of reported changes in rainfall patterns..........70

Table 9. Advantages and disadvantages of increased temperatures..............71

Table 10. Respondent's observation regarding water loss in creeks over the previous 5 to 7 years...................................... 72

Table 11. Average on-farm economic losses from the consequences of climate change (NRs. '000/family) during the previous 5 to 7 years..........73

Table 12. Adaptation measures in study regions............................74

Table 13. Reasons for not adopting resiliency measures....................75

Table 14. Reasons of land use pattern change............................ 75

Table 15. Preferred adaptation approaches (agricultural water)...............77

Table 16. Preferred measures to support effective adaptation..................78

Table 17. Binary logit analysis of decision to adopt adaptation measures in the Mountain region $(\mathrm{n}=150)$

Table 18. Binary logit analysis of decision to adopt adaptation measures

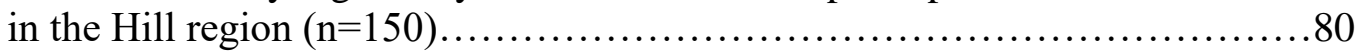

Table 19. Binary logit analysis of decision to adopt adaptation measures in the Terai region $(n=150)$

\section{Essay Three Tables}

Table 1. Characteristics of major river basins and food insecurity by 2050 in the South Asian region.

Table 2. Cropping intensity (ratio) in three ecological belts of the study area.

Table 3. Water Conveyance Efficiency (WCE) in different eco-regions

Table 4. Overall agronomic water use efficiency (WCE) of farms in three eco-regions 
Table 5. Economic indicators for irrigated and unirrigated conditions

Table 6. Average farm productivity under irrigated and unirrigated

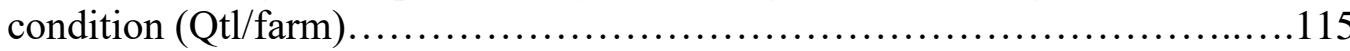

Table 7. WTP for additional water availability............................116

Table 8. Respondent's observation on \% water loss in creeks in the $10-15$ years................................................... 117

Table 9. Factor affecting water use efficiency in the Terai region..............121

Table 10. Factor affecting water use efficiency in the Hill region..............124

Table 11. Factor affecting water use efficiency in the Mountain region........125

Table 12. Tobit regression on censored value of agronomic water use efficiency $\left(E_{a}\right)$ in the study regions................................. 126 


\title{
THREE ESSAYS ON ECONOMICS OF WATER RESOURCES MANAGEMENT IN NEPAL
}

\author{
Krishna Lal Poudel \\ Dr. Thomas G. Johnson, Dissertation Supervisor
}

\begin{abstract}
First essay consists of two steps. First, Technical Efficiency (TE) index is estimated for upriver and downriver ecoregions employing DEA technique. In the second stage, we censored the TE index and run the Tobit regression model to assess the socio-economic factors responsible for explaining technical efficiency of smallholder farming practices. The median technical efficiency values were 0.606 and 0.756 in upriver and downriver respectively. Tobit model indicates lower productivity of small scale farming units are due to inadequate water availability, lack of reliable inputs and poor market services. Access to farm credit and electricity are significant and positive factors explaining technical efficiency in both regions. The second essay examines the on-going consequences of climate change on water resources availability and how adaptation practices and strategies have developed in agricultural practices. Results indicate increasing temperatures, prolonged drought followed by intense precipitation, and greater frequency of flooding than in the past. About two-thirds of small creeks and springs have disappeared and others will soon disappear if current trends continue. Respondents prefer collective water management. Logistic regression analysis shows that farm income, market access, access to extension services, and market distance are significant predictors of adaptive behavior. Essay-3 deals the conveyance, economic and agronomic efficiency of water used, and factors affecting aggregate water use efficiency in the study regions. Farmers in the Mountain region were found relatively more effective at reducing water loss than farmers in the Hill and Terai regions. Water use efficiency scores regressed on farm related socio-economic variables shows that farm size, distance to water source, government agricultural extension services and access to credit positively affect water use efficiency in all regions.
\end{abstract}




\section{INTRODUCTION}

South Asia currently faces challenges accessing sufficient water for agriculture to feed its burgeoning population (FAO, 2012). Water demand is growing even as the supply is limited and uncertain. Climate change is exacerbating the problem. The IPCC (2007a) projects that for every $1^{\circ} \mathrm{C}$ rise in temperature, agricultural water demand increases by 6 to $10 \%$ or more. It is expected to cause a $4-10 \%$ cereal production decrement in South Asian countries by the end of this century. ICIMOD studies find that warming in the greater Himalayas has been much greater than the global average which would further stress the agricultural water management (Eriksson et al., 2009).

This growing water shortage will have numerous follow-on impacts. Water shortages will ultimately create food insecurity and lower living standards especially for the most vulnerable members of society. Other consequences of the nexus of wateragriculture-climate change are the spatial consequences. There is a high degree of dependency of downstream communities on upstream ecosystem services for quality water especially during the dry-season (Rasul, 2014).

About 0.99 million of the 2.97 million hectares of total cultivable land in Nepal is cultivated. The average land holding of $75 \%$ of the population is less than a hectare (CBS, 2007). Small scale subsistence farms generally lack sufficient irrigation facilities. Only $24 \%$ of arable land is irrigated. Nearly $85 \%$ of rainfall occurs during the monsoon period of June to September. During the rest of the year, severe water shortages are 
experienced by agriculture, households and hydropower plants. Because the country lies in the monsoon zone, major staple crops are cultivated during this season.

There is a wide variation in temperature and precipitation among the different ecological regions. The Mountain region receives less precipitation than the Hill and Terai regions. Lowland agriculture receives irrigation from the Himalayan glacier system which is expected to suffer from lack of dry season water. The estimated glacial melt water contribution is, for example, $20 \%$ to $40 \%$ in rivers in Western China (Tao et al., 2005), equal to or greater than 50\% in the Indus (Tarar, 1982), and $30 \%$ in the Nepalese river during the pre-monsoon season (Sharma, 1993).

Welfare economics demonstrates how accurate information about the risks associated with phenomena such as weather and climate have important implications for the utility derived from consumption and for the net income earned by producers. If consumers and producers do not have accurate information, they are unable to choose strategies that increase consumer utility and producer quasirent (Just et al., 2004).

This research aims to better understand the major crop production in the Koshi river basin and compare farming system efficiency from both inputs (farm size, water, labor and capital) and output management aspects. The efficiency of input use is indicated by technical efficiency (TE) while the efficiency of output management is indicated by allocative efficiency (AE). Comparing efficiency and productivity of farms in upriver and downriver ecoregions will inform decision makers regarding their adoption 
of feasible agronomic and economic strategies. Farmers in the regions are already experiencing the impacts of climate change on water resources and traditional farming practices. However, farmers are also adopting various adaptation strategies to some extent. This dissertation identifies these adaptation practices and assesses how would they change the local economies.

Scarce water resources must be allocated between various competitive uses. Agriculture is one of the essential water uses. Water resource management efficiency from its source to the farm land is an important determinant of the economic return per unit of available water in the region. This study is intended to support policy actions to develop more economically and environmentally sound mountain farming systems, and to improve the living standards of mountain populations and populations living downstream - now, and in the future. A major output of the current research is a model for studying water management to enhance sustainable strategies for Nepalese farmers.

\section{STUDY SITE, SAMPLING AND DATA}

Koshi, the largest glacier-fed river of Nepal passes through the Mountain, Hill and Terai regions and ultimately confluences with the Ganges river in India. The Koshi River basin was chosen for this study. The Koshi River is $720 \mathrm{~km}$ long and drains a $61,000 \mathrm{~km}^{2}$ basin (Erickson et al. 2009; WESC, 2011). The high-Hill and Mountain sections of the basin were considered the upriver (upstream) ecoregion while the lower-Hill and Terai region is defined as the downriver (downstream) ecoregion. Physiographic characteristics 
of the upriver and downriver regions and three ecological regions of the Koshi river basin are presented in Table 1 and 2 respectively. Study regions are shown in figure 1.

Notations and definitions of the variables relevant to the study are illustrated in Table 3.

Table 1. Climate characteristics of upriver and downriver regions

\begin{tabular}{lllll}
\hline $\begin{array}{l}\text { River basin } \\
\text { bands }\end{array}$ & $\begin{array}{l}\text { Altitude } \\
(\mathrm{msl})\end{array}$ & \multicolumn{1}{c}{ Climate } & $\begin{array}{l}\text { Average } \\
\text { annual } \\
\text { precipitation }\end{array}$ & $\begin{array}{l}\text { Mean annual } \\
\text { temperature }\end{array}$ \\
\hline Upriver & $791-4775$ & Cool/artic/alpine & $150 \mathrm{~mm}-2300 \mathrm{~mm}$ & $<3^{\circ} \mathrm{C}-17^{\circ} \mathrm{C}$ \\
Downriver & $178-790$ & Tropical/subtropical & $1100 \mathrm{~mm}-3000 \mathrm{~mm}$ & $20^{\circ} \mathrm{C}-45^{\circ} \mathrm{C}$ \\
\hline
\end{tabular}

Source: Adapted and modified from WECS (2011).

Table 2. Climate characteristic in three ecological belts of Nepal

\begin{tabular}{lrrll}
\hline $\begin{array}{l}\text { Ecological } \\
\text { belt }\end{array}$ & $\begin{array}{l}\text { Percent of } \\
\text { total land } \\
\text { area }\end{array}$ & \multicolumn{1}{c}{ Geology and soil } & $\begin{array}{l}\text { Average } \\
\text { annual } \\
\text { precipitation }\end{array}$ & $\begin{array}{l}\text { Mean annual } \\
\text { temperature }\end{array}$ \\
\hline Mountain & 35 & Limestone and shale, stony soils & $\begin{array}{l}\text { Snow } / 150 \mathrm{~mm}- \\
200 \mathrm{~mm}\end{array}$ & $<3^{\circ} \mathrm{C}-10^{\circ} \mathrm{C}$ \\
Hill & 42 & $\begin{array}{l}\text { Sandstone, siltstone, steep slopes, } \\
\text { course textured soils, coniferous forest }\end{array}$ & $\begin{array}{l}275 \mathrm{~mm}- \\
2300 \mathrm{~mm}\end{array}$ & $10^{\circ} \mathrm{C}-20^{\circ} \mathrm{C}$ \\
Terai & 23 & $\begin{array}{l}\text { Gentle slope and recently deposited } \\
\text { alluvium, fine textured soils, highly } \\
\text { fertile land }\end{array}$ & $\begin{array}{l}1100 \mathrm{~mm}- \\
3000 \mathrm{~mm}\end{array}$ & $20^{\circ} \mathrm{C}-25^{\circ} \mathrm{C}$ \\
& & & \\
\hline
\end{tabular}

Source: Adapted and modified from: Agrawal et al. (2003); Manandhar et al. (2011) 


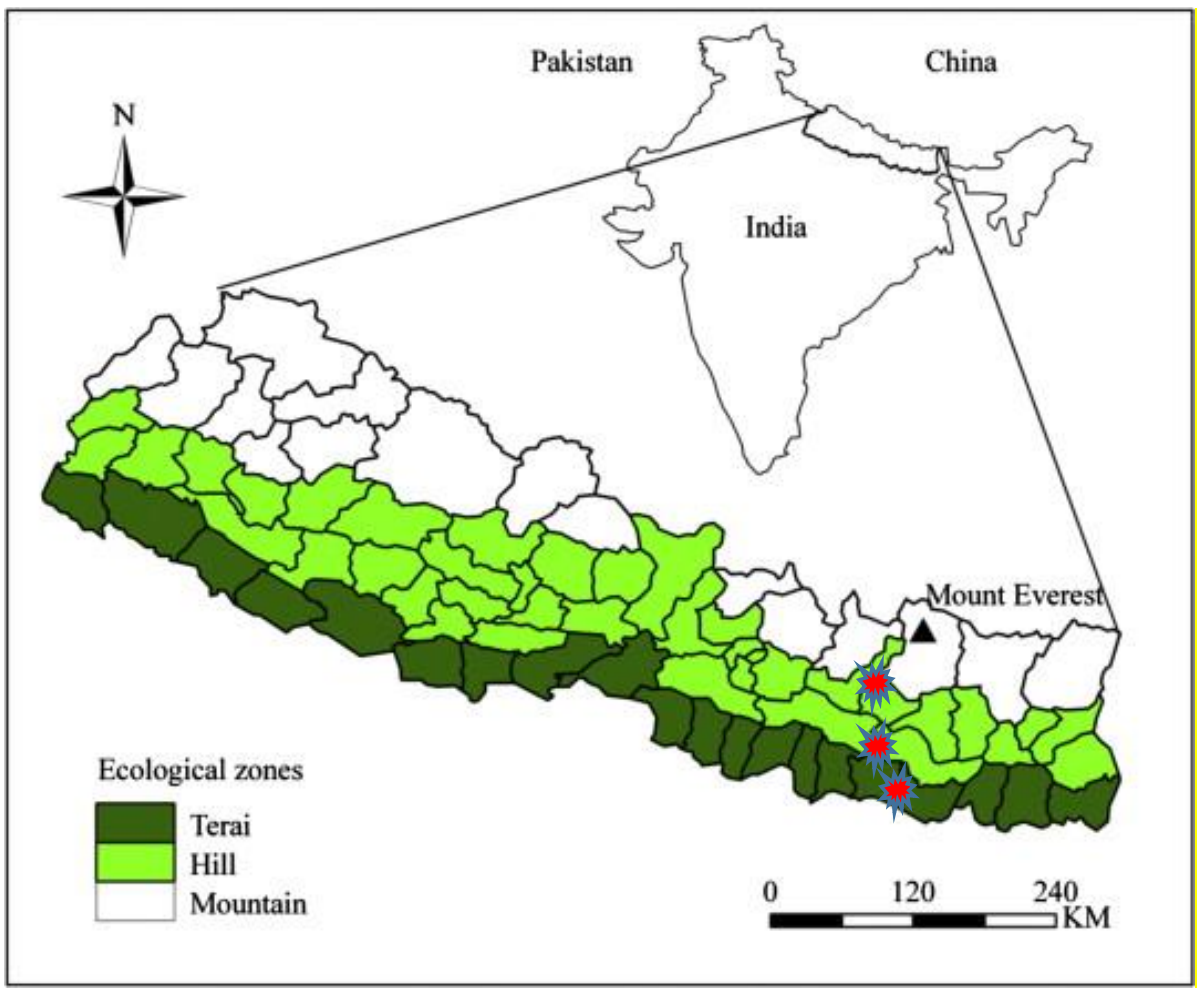

Fig. 2 Ecological zones and study sites of Nepal. Study areas:

Source: adapted from http://www1.american.edu/ted/ICE/terai.html

A face to face survey of randomly selected 450 households of three ecological regions of the Koshi river basin of Nepal-Mountain, Hill and the Terai regions was carried out during April- November, 2015. The survey employed a pre-tested semistructured questionnaire. In addition to survey, participatory approaches were deployed to explore the various facets of the study objectives. Some participatory tools ${ }^{1}$ used were

${ }^{1}$ These participatory tools help in preparing case studies as well. Case studies are generally deemed to lack rigor and objectivity as compared to other social science research such as survey research methods. A case study could be advantageous if extra care is given to articulate research design. Rowley (2002) argued the case studies are widely used because of the insight they offer that might not be achieved with other approaches. Case studies are particularly applicable to novice research fields or research areas where existing theory seems inadequate (Eisenhardt, 1989). Case studies enable the researcher to understand in more detail the issues that answer the how and why questions. Yin 
Focus Group Discussion (FGD) and Key Informant Survey (KIS) during the period of field study. Several telephone and email contacts were also made to verify some information and receive new data as well. The broader goal of the survey was to examine the on-going consequences of climate change on water resource availability and its allocation in upriver-down river regions, adaptation strategies and thereby achieved water use efficiency of the farming practices. Study area was organized into two regions: upriver and downriver for farming system efficiency analysis in essay-1 while essay- 2 and essay-3 were written on the data collected from three ecological regions. Secondary data from various sources were also used where it was needed.

(1994) writes "A how or why question is being asked about a contemporary set of events over which the investigator has little or no control". 
Table 3. Variables definition and measurement

\begin{tabular}{|c|c|c|}
\hline Variables & Unit & Definitions (...for farm $\mathrm{j}$ ) \\
\hline Age & Year & $\begin{array}{l}\text { Age of household head who manage farming } \\
\text { activities }\end{array}$ \\
\hline Gender & 1,0 & 1 if the farm manager is male, 0 otherwise \\
\hline Literacy & 1,0 & 1 if the household head is illiterate, 0 otherwise \\
\hline $\begin{array}{l}\text { Household } \\
\text { size }\end{array}$ & $\begin{array}{l}\text { No. of } \\
\text { person }\end{array}$ & Number of individuals in a family living together \\
\hline $\begin{array}{l}\text { Residence } \\
\text { area }\end{array}$ & 1,0 & 1 if the residence in rural area, 0 otherwise \\
\hline Farm size & Ropani* & Area of the agricultural farming land \\
\hline Output & Qtl/farm & Quantity of cereal produced \\
\hline Output price & Rs/Qtl & $\begin{array}{l}\text { Market value of farm produces in the prevailing } \\
\text { market }\end{array}$ \\
\hline Capital & Rs./Farm & $\begin{array}{l}\text { Tillage, pesticide, equipment and irrigation devices } \\
\text { etc. }\end{array}$ \\
\hline Labor & $\begin{array}{l}\text { Man } \\
\text { days/farm }\end{array}$ & $\begin{array}{l}\text { Number of labors employed in the farm during the } \\
\text { production }\end{array}$ \\
\hline Labor cost & $\begin{array}{l}\text { Rs/person/d } \\
\text { ay }\end{array}$ & $\begin{array}{l}\text { Cost of using a labor ( } 8 \text { hours) in a day in the farming } \\
\text { related activities }\end{array}$ \\
\hline Farm income & $\begin{array}{l}\text { Rs \# } \\
(' 000)\end{array}$ & $\begin{array}{l}\text { Net revenue obtained from the farming activities in a } \\
\text { year }\end{array}$ \\
\hline Market access & 1,0 & $\begin{array}{l}1 \text { if the respondent have access to roads and means of } \\
\text { transportation to carry their marketable products to } \\
\text { the trading centers, } 0 \text { otherwise }\end{array}$ \\
\hline $\begin{array}{l}\text { Extension } \\
\text { services }\end{array}$ & 1,0 & $\begin{array}{l}1 \text { if respondent receives regular agricultural extension } \\
\text { services from government in the community level, } 0 \\
\text { otherwise }\end{array}$ \\
\hline $\begin{array}{l}\text { Contemplating } \\
\text { migration }\end{array}$ & 1,0 & $\begin{array}{l}\text { 1, if respondent is planning enough to migrate outside } \\
\text { the region/community, } 0 \text { otherwise }\end{array}$ \\
\hline Credit access & 1,0 & $\begin{array}{l}1 \text { if respondent have easy access to formal financial } \\
\text { institutions to receive loan to agricultural enterprises, } \\
0 \text { otherwise }\end{array}$ \\
\hline $\begin{array}{l}\text { Market } \\
\text { distance }\end{array}$ & $\mathrm{Km}$ & $\begin{array}{l}\text { How far the production farm and/or residence location } \\
\text { is from the agricultural commodity (inputs/outputs) } \\
\text { trading centers }\end{array}$ \\
\hline Water cost & Rs & Cost of water (per litter) used in farms and household \\
\hline $\begin{array}{l}\text { Distance Ag } \\
\text { water source }\end{array}$ & $\mathrm{Km}$ & Distance of water sources for agricultural usage \\
\hline $\begin{array}{l}\text { Distance } \mathrm{HH} \\
\text { water source }\end{array}$ & $\mathrm{Km}$ & Distance of water sources for household purposes \\
\hline Water used & Lit/day & Amount water used in crop, livestock and household \\
\hline Livestock size & No. & Number of livestock ( cattle, goat and pig) \\
\hline
\end{tabular}


Essay-one estimates the technical, allocative and cost efficiency of farms in the region. Using these estimates it then explores the factors explaining the technical efficiency in the farming community. The study region was divided into upriver and downriver. The sample for each region was 225 responses. Data Envelopment Analysis technique was used to estimate various types of efficiencies. Tobit regression was applied to identify the factors affecting technical efficiency (TE) of smallholder farming practices.

Essay-two examines the on-going consequences of climate change on water resource availability and how adaptation practices and strategies have developed in three ecological regions. Logistic regression analysis is used to determine how farm income, market access, access to extension services, desire to emigrate, and distance from the market relate to adaptive behavior in the region.

Essay-3 examines the conveyance, economic and agronomic efficiency of water used, and factors affecting aggregate water use efficiency in the study regions. Water use efficiency scores are regressed on farm related socio-economic variables using two models - Ordinary Least Square and Tobit regression to determine how farm size, distance to water source, government agricultural extension services and access to credit affect water use efficiency. 


\section{ESSAY 1: Smallholder Farming Efficiency in Upriver-Downriver Ecoregions of the Koshi River in Nepal}

\section{Rationale of the Study}

In recent decades, anthropogenic endeavors have brought undesirable outcomes such as forest clearing, unplanned urban center development, loss of productive farm land due to inundation, degradation of wetland etc. in the major river basin of Nepal. Land use patterns are changing but with little adherence to scientific considerations. The cropland area declined by $90 \mathrm{~km}^{2}$ between 1978 and 2010 in the Koshi river basin (Paudel et al. 2016). This may be due to topographic, socioeconomic and/or hydrological changes. This research aims to better understand the major crop production in the Koshi river basin and compare farming system efficiency from both inputs (farm size, water, labor and capital) and output management aspects. The efficiency of input use is indicated by technical efficiency (TE) while the efficiency of output management is indicated by allocative efficiency (AE). Comparing efficiency and productivity of farms in upriver and downriver ecoregions will inform decision makers regarding their adoption of feasible agronomic and economic strategies.

The most direct way to increase the productivity in small scale farming systems is to use available resources more efficiently with existing technologies. Bravo-Ureta and Reiger (1991) explain that efficiency measurement is important because it can lead to substantial resource savings. 
Efficiency measures can be estimated using nonparametric or parametric approaches. Data envelopment analysis (DEA) is a popular nonparametric method. The nonparametric approach does not impose any parametric restrictions on technology and there is no need to assume a particular functional form for production relationships, which makes the process of calculating efficiencies more flexible (Ray, 2004). This study will produce feasible production planning guidelines considering resource base and prices in order to identify profit maximizing strategies for small holder farming units in the river basin.

Water resources are abundant throughout Nepal in the form of snow cover, rivers, springs, lakes, and groundwater. The total renewable surface water resource (i.e. excluding ground water) of the country is estimated to be $225 \mathrm{~km}^{3} / y e a r$. A majority of the big rivers originate in the Himalayan mountains. Most of the mountain areas of Nepal are covered with snow and produce freshwater for the downstream rivers and wetland. The mountain region contains about 3,252 glaciers with a total area of 5,323 $\mathrm{km}^{2}$ and about 2,323 glacial lakes with total area of $75.70 \mathrm{~km}^{2}$ (WECS, 2011, Erickson et al. 2009).

The upriver ecoregion contains numerous water bodies such as lakes, ponds, dams, small wetlands and glacial lakes ${ }^{2}$. The downriver ecoregion is characterized by

\footnotetext{
${ }^{2}$ Recent report of the National Lakes Conservation Development Committee has identified total 5,358 lakes in Nepal (including 2323 glacial lakes)
} 
tributaries, springs, lakes and larger wetlands ${ }^{3}$. The flow in these rivers is mostly dependent on monsoon precipitation and their flow level typically declines significantly during the non-monsoon period. The summer monsoon period is important as about 60$85 \%$ of annual runoff of all river systems in Nepal occurs during July to September.

\section{Literature Review}

Development economists (for example, Johnston and Mellor, 1961; Hayami and Ruttan, 1985) have long recognized the role of agriculture in the economic development process. For this reason, the adoption of new technology has received a great deal of attention in developing countries. However, agricultural growth is not only determined by the level of technology but also by the level of efficiency that is associated with the utilization of a given technology. The potential contribution of efficiency to the overall output growth has yielded a number of studies of production efficiency (Bravo-Ureta and Pinheiro, 1993). Several hypotheses have been tested to understand the causes of low production efficiencies in developing countries. One of the well accepted hypotheses proposed by Schultz (1964) says that poor farmers in developing countries are actually efficient given their socio-economic circumstances. This hypothesis has had a strong influence in shaping the agricultural development policy in developing countries. Policy

${ }^{3}$ The wetlands of the country's lowlands alone support 32 species of mammals, 461 species of birds (among which 15 species are rare), 9 species of turtle, 20 species of snake and 28 species of fish. 
makers overlooked inexpensive ways of increasing agricultural production through increasing efficiency and focused only on expensive options such as investment in new technology. The poor but efficient hypothesis assumes that the external conditions are steady and farmers are in a continuous equilibrium. In reality, farmers find themselves in disequilibrium because of continuously generated new technology and variations in input and output prices (Ali and Chaudhari, 1990). Thus, in contrast to Schultz's hypothesis, many studies have hypothesized that farmers in developing countries have failed to exploit the existing technology irrespective of whether it is traditional or modern. For example, a study by Ali and Flinn (1989) concluded that profits of rice farmers in Pakistan's Punjab could be increased by $28 \%$ through enhancing efficiency using the existing technology. Similarly, many other studies carried out in developing countries have found similar results (Jamison and Moock, 1984; Squires and Tabor, 1991; Tadessea and Krishnamurthy, 1997; Dhungana et al, 2004; Idiong, 2007; Rahman, 2010). Thus, technological advancement may not bring the expected impact if inefficiency is pervasive in farming business.

Past studies have also explained the gap in technical efficiency as mainly due to socio-economic characteristics of farm households. Infrastructure, soil fertility, experience, access to extension services, tenancy and non-agricultural share of income were the main factors affecting the efficiency of rice farms in Bangladesh, (Rahman, 2010). Similarly, Brazdik (2006) found that rapid land fragmentation was an important factor affecting the technical efficiency of rice farms in West Java, Indonesia during the Green Revolution. 
Production is technically efficient, if production occurs on the boundary of a production possibility curve and is allocatively efficient if it occurs in a region of the production possibilities set that satisfies the producer's behavioral objective and market forces. Thus, economic efficiency is the product of technical and allocative efficiency. An economically efficient input-output combination would be on the frontier function as well as on the expansion path.

Efficiency analysis depends on certain assumptions about the behavior of firms. The behavior of production entities can be described either using production functions, cost functions, profit functions, or demand and supply functions. It is assumed that a producer's goal is to either maximize profit or minimize cost. However, there are different economic theories of peasant household behavior, which assume that peasant households maximize one or more household objectives (Mendola, 2007).

Agricultural farms are very heterogeneous in developing countries, and very few are commercialized while many are still subsistent. Due to imperfect information in subsistence farming, the informal institutional arrangements lead to high efficiency costs (De Janvry et al, 1991). In commercial farming, competition in the market forces farmers to make decisions that tend to more effectively utilize given technology to its maximum extent. In the case of subsistence farming, production decisions tend to be based on local informal institutions. Such systems do not create competitive environments which, in turn, allow continued inefficiency in production. 
This study analyzes the nature and causes of inefficiencies in the agricultural systems of the Koshi River Basin, with the goal of identifying opportunities for increasing productivity and economic outcomes in the region. This is especially important given the rapidly changing natural and social environment in the region.

\section{Guiding Economic Theory}

Efficiency is typically compared among various categories such as regions, farm

size, tenure system and, more recently, upriver (upstream) - downriver (downstream). The concept of efficiency in economics is a complex and dynamic issue. The rates of adoption and diffusion of agricultural production technology by farmers significantly changes economies of scale and thus efficiencies of particular farms.

To achieve higher productivity, farmers must either adopt recent technological innovations, or make more efficient use of available technologies, or both. Schultz (1964) argued that, given their resources small farmers generally combine inputs in manners which yield maximum profit; that is peasants are "poor but efficient". Technological advancement (green revolution) and better use of existing technology both have been effective during the last few decades in enhancing productivity in the farming practices. In developing countries, most new agricultural technologies have only been partially successful (Xu and Jeffrey, 1998). It has generally been more cost effective to motivate farmers to improve efficiency rather than to adopt radically new technology, especially 
when farmers are not efficiently using the existing technology (Belbase and Grabowski, 1985).

The seminal work of Farrell (1957) who argued that efficiency could meaningfully be judged in a relative sense, as a deviation from the best practices of a representative peer group of producers (farmers in our research). Farrell further differentiated between technical efficiency (where maximum output is obtained from a given set of inputs) and allocative efficiency (where given prevailing input prices, factors are used in proportions which maximize profits). Simultaneous achievement of both technical and allocative efficiency ensures economic efficiency. Figure 1 explains these different types of efficiency concepts.

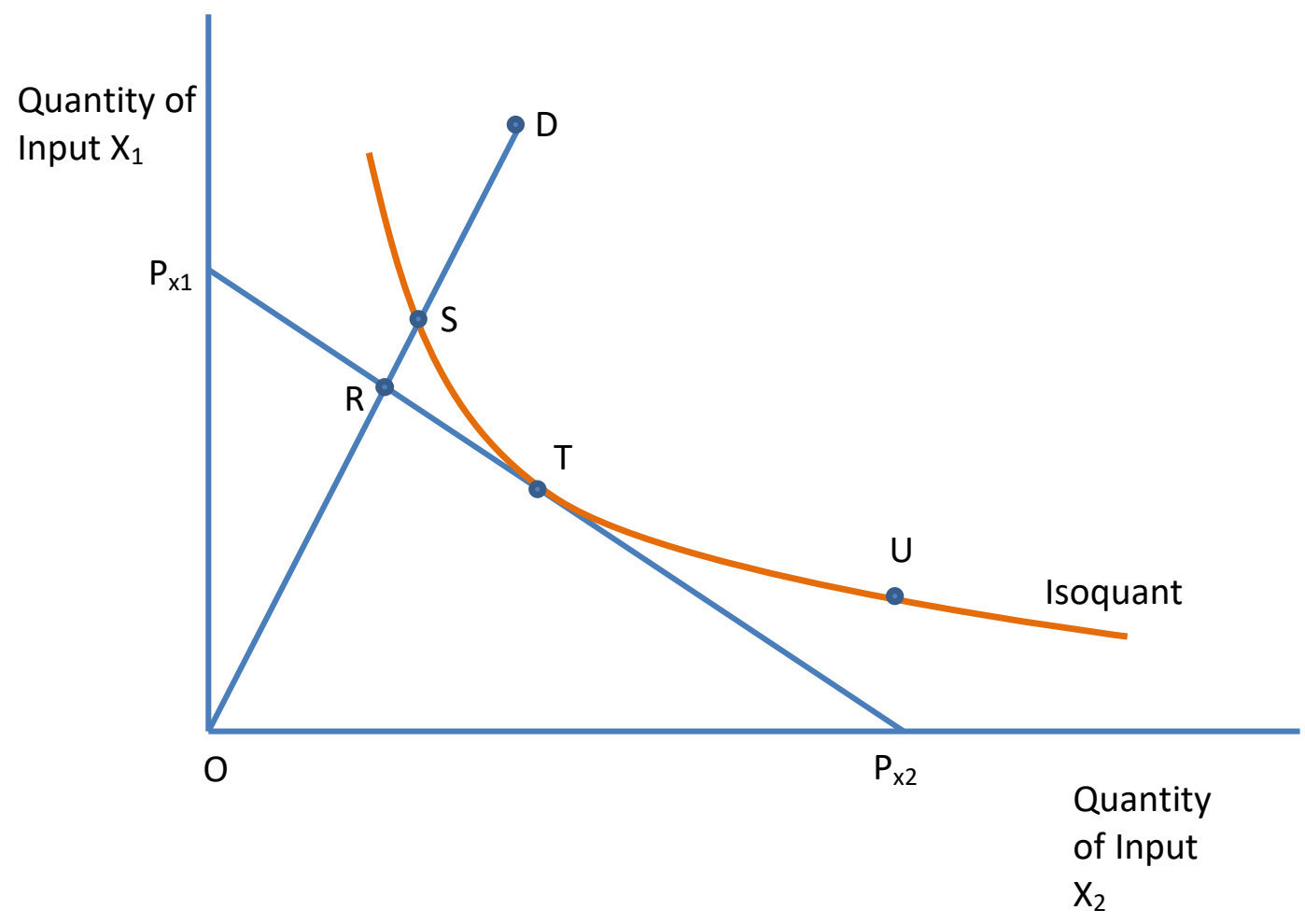

Fig. 1. Farrell's efficiency indices 
Figure 1 shows the efficient unit isoquant for a group of farms ( $\mathrm{S}, \mathrm{T}$ and $\mathrm{U}$ farms) using inputs $\mathrm{X}_{1}$ and $\mathrm{X}_{2}$. All farms operating on the isoquant use the least amount of inputs $\mathrm{X}_{1}$ and $\mathrm{X}_{2}$ to produce the predetermined level of output. Here $\mathrm{S}, \mathrm{T}$ and $\mathrm{U}$, being on the isoquant, are technically efficient but $\mathrm{D}$ is not. The measure of technical efficiency for farm $\mathrm{D}$ is given by the ratio, OS/OD; that is farm $\mathrm{D}$ could reduce both inputs by a proportion OS/OD and still produce the same level of output. Given relative input prices, the isocost line $\mathrm{P}_{\mathrm{x} 1} \mathrm{P}_{\mathrm{x} 2}$ indicates the minimum cost of producing one unit of output. Farm $\mathrm{T}$ achieves greatest economic efficiency because it lies on the tangential point between the isocost line and isoquant. Farm $\mathrm{R}$ has the same level of cost as farm $\mathrm{T}$ but produces below the isoquant, and therefore at a lower level of output. The overall economic efficiency of farm D is measured as OR/OD. The allocative efficiency (the divergence between the minimum cost point and the cost incurred at point $S$ ) for farm $D$ is OR/OS. Farrell (1957) decomposed overall economic efficiency as follows:

Economic Efficiency $(E E)=$ Technical Efficiency $(T E) \times$ Allocative Efficiency $(A E)$
$O R / O D=O S / O D * O R / O S$

From the definition above, farm T would be economically efficient, farms $U$ and S would be technically efficient but not allocatively efficient, and farm D would be neither technically nor allocatively efficient.

Note that TE achieves maximum output given the production function and available inputs. Technical efficiency is an important goal but in market driven 
situations, profit maximization ${ }^{4}$ is the ultimate goal. Specifically, how well informed decision making could be an instrument to achieve overall efficiency for the farming unit is illustrated in the various panels of figure 2 below.

\subsection{Technical, Allocative and Economic Efficiency}

In Figure 2(a), farm D exhibits both technical and allocative inefficiency whereas farm $\mathrm{C}$ on the same total physical product $\left(\mathrm{TPP}_{2}\right)$ curve is allocatively efficient but technically inefficient. Farm $\mathrm{B}$ on the $\mathrm{TPP}_{1}$ is technically efficient but allocatively inefficient. Farm A displays both technical and allocative efficiency thus achieving overall economic efficiency in terms of input management. Farms are assumed to operate on the outer bound of the possible production space (i.e. on the production function). In both Figures 2(b) and 2 (c) subscript 1 indicates the technically superior set of production conditions. Point D displays both technical and allocative inefficiency, C displays allocative efficiency but technical inefficiency, B displays technical efficiency but allocative inefficiency, and the point A defines the unique point of economic efficiency. In order to investigate the efficiency attributes of farms two types of information are required (Ellis, 1993):

\footnotetext{
${ }^{4}$ Neoclassical theory of production suggests three important decision making conditions for profit maximization. In factor-product relations, the economic optimum level of inputs occurs when the marginal value product (MVP) of the input is equal to the price of the inputs i.e. $M V P_{x}=P_{x}$. In factor-factor relations, ratios of marginal physical products (MPP) to unit costs are the same for all inputs i.e. $M P P_{1} / M P P_{2}=P_{1} / P_{2}$. And in product-product relations the optimum choice of enterprise occurs when the marginal value product per unit of variable resource is equal in all enterprises, i.e. $\operatorname{MVP}\left(\mathrm{Y}_{1}\right)=\operatorname{MVP}\left(\mathrm{Y}_{2}\right)$, also called the principle of equi-marginal returns.
} 
- Farms' varying degree of success at maximizing output from given levels of inputs; and

- Farms' choices with respect to the relative prices of inputs and outputs.

The first set of information explains the technical efficiency dimension while the latter is oriented towards allocative (price) efficiency dimension. Meanwhile, it is possible to set up and estimate a production function with variables of interest (water in this case). That would be instrumental to judge whether the principal factors of production are under, over or properly utilized by equating MVP with marginal input cost (MIC).

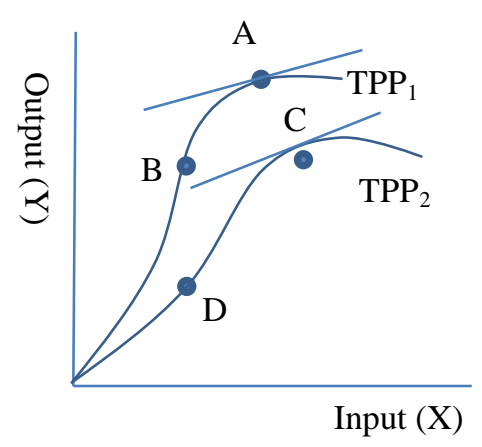

(a) Factor-product relation (Technical and price efficiency)
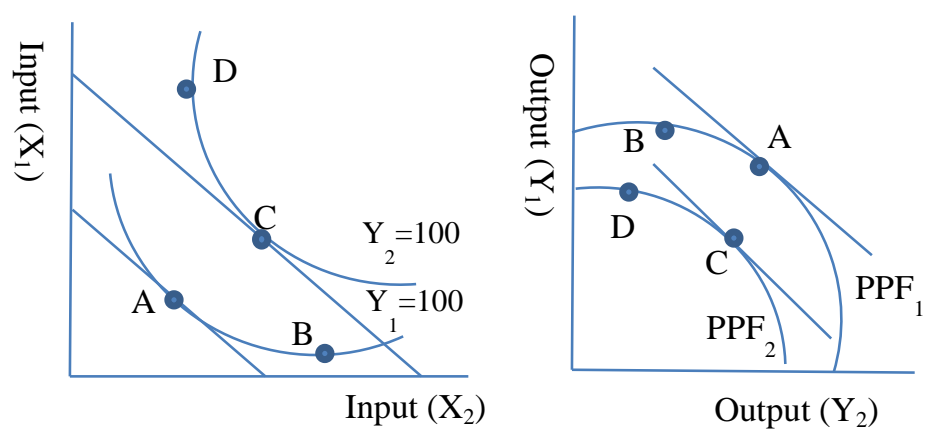

(b) Factor-factor relation (Isoquants and efficiency)

(c) Product-product relation (Production frontiers and eficiency)

Figure 2. Technical, Allocative and Economic Efficiency

Long enduring farming enterprises typically invest in durable capital such as irrigation facilities, seed storage, farm machinery, etc. The goal of farm managers then is 
to maximize their return on this investment. This can be illustrated through the following objective function:

$$
\operatorname{Max} N P V=\sum_{n=1}^{N} N R_{n}(1+k)^{-n}
$$

Where NPV is the net present value of net farm revenue (received from the transaction of farm output in the $\mathrm{i}^{\text {th }}$ farm, $\mathrm{k}$ represents the discount rate (mostly reflecting market interest rates), and $N R_{n}$ represents net revenue over n period. Here, the bounds of summation for the net revenue $\left(\mathrm{NR}^{5}\right)$ are from the beginning year of the decision to start or continue farming to an undefined future time period, N. During this time period many factors including the quality and quantity of inputs and outputs, prices of inputs and outputs, opportunity costs of assets, and technology keep changing.

\section{Analytical Framework}

From economic production theory, economists characterize a technology as the transformation of inputs into outputs and conceptualize this transformation by a production function. Production functions are the foundation of studies of productivity and efficiency. Productivity is the return on applied inputs; paddy harvest per kg nitrogenous fertilizer, for example. Estimation of efficiency can be achieved using either parametric or non-parametric methods. This study uses a non-parametric method- Data Envelopment Analysis (DEA) developed by Charnes et al. (1994). DEA measures the

\footnotetext{
${ }^{5}$ In the initial period the cost or opportunity cost of committed investment is included in NR.
} 
productivity and efficiency of a decision making unit $\left(\mathrm{DMU}^{6}\right)$ based on linear optimization by creating the benchmark function- 'frontier' from the observed data sets via an optimization condition. So the best observed DMUs define the so-called 'best practice frontier' (Coelli et al. 2005). This process is demonstrated in figure 3 . The distance between red (observed farms) and blue dots (software generated benchmarked farms) is inefficiency.

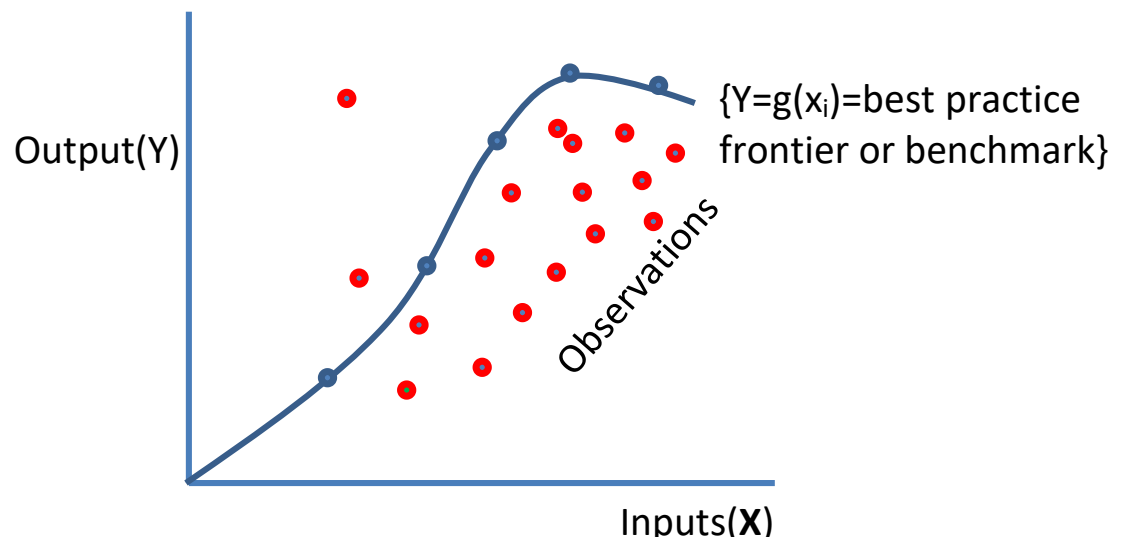

Figure 3. DEA simulated best practice frontier

The advantages of the DEA techniques include its straightforward interpretation, and feasibility of estimating a production frontier with few observations. DEA does not require the analyst to define a particular functional form for the production process. Weaknesses of DEA are that random impacts on the observations (e.g. measurement error) are treated as real and deterministic data and that a few observations can significantly influence the estimation of the frontier (Lanker et al. 2012). Efficiency

\footnotetext{
${ }^{6}$ Agricultural farm in both upriver and downriver basin
} 
measures can be biased by outliers in the data. Besides the core production variables, there are a number of factors that influence the technical efficiency of farms, often referred to as 'determinants of technical efficiency'. The DEA approach typically does not include a large number of socio-economic variables which are plausibly useful in explaining technical and allocative efficiency-framework. These socio-economic variables, often called "factors affecting technical efficiency," can be incorporated in a second stage-estimation Tobit-model with censored technical efficiency scores although there has been a debate over using Tobit regression in this manner (Hoff 2007; McDonald 2009).

TE is defined as the ability of a farm to either produce the maximum possible output from a given set of inputs and a given technology, or to yield the given level of output from the possible minimum quantum of inputs. Färe and Lovell (1978, p. 152) defined technical efficiency as the "degree to which the actual output of production unit approaches its maximum”. Färe et al. (1994) recommend the input oriented DEA approach to illustrate TE via a linear programming (LP) method. In particular, Farrell (1957) proposes this piece-wise-linear convex hull approach to frontier estimation. Assuming that each of I farms has access to $\mathrm{N}$ inputs and can produce any of $\mathrm{M}$ outputs then the input and output vectors of $\mathrm{i}^{\text {th }}$ farm is an $\mathrm{N}^{*} \mathrm{I}$ input matrix $\mathbf{X}$ and an $\mathrm{M}^{*} \mathrm{I}$ output matrix $\mathbf{Y}$. The expected ratio of all outputs to overall inputs is determined by assigning optimal weights to inputs and outputs based on a solution to a mathematical programming problem. We followed Coelli et al. (2005) in formulating the necessary equations needed by the DEA program. Here, $u$ is an $M^{*}$ I vectors of output weights and $v$ is an $\mathrm{N}^{*} \mathrm{I}$ vectors of inputs weights. 


$$
\begin{aligned}
& \max _{\mathrm{u}, \mathrm{v}}\left[\mathbf{u}^{\prime} \mathbf{y}_{\mathrm{i}} / \mathbf{v}^{\prime} \mathbf{x}_{\mathrm{i}}\right] \\
& \text { st } \quad\left[\mathbf{u}^{\prime} \mathbf{y}_{\mathrm{j}} / \mathbf{v}^{\prime} \mathbf{x}_{\mathrm{j}}\right] \leq 1, \quad \mathrm{i}=1,2, \ldots, \mathrm{I} \text {, } \\
& \mathbf{u}, \mathbf{v} \geq \mathbf{0}
\end{aligned}
$$

Equation (1) involves solving for $u$ and $v$, such that the efficiency measures for the $\mathrm{i}^{\text {th }}$ firm is maximized subject to the constraints that the efficiency value be less than or equal to 1 . To overcome the problem of an infinite number of solutions from this specific ratio formulation, we impose the constraint $\mathbf{v}^{\prime} \mathbf{x}_{\mathrm{i}}=1$, then

$$
\begin{array}{ll}
\max _{\mu, \mathrm{v}} & {\left[\boldsymbol{\mu}^{\prime} \mathbf{y}_{\mathrm{i}}\right],} \\
\text { st } \quad & \mathbf{v}^{\prime} \mathbf{x}_{\mathrm{i}}=1, \\
& \boldsymbol{\mu}^{\prime} \mathbf{y}_{\mathrm{j}}-\mathbf{v}^{\prime} \mathbf{x}_{\mathrm{j}} \leq 0, \quad \mathrm{j}=1,2, \ldots \ldots, \mathrm{I}, \\
& \boldsymbol{\mu}, \mathbf{v} \geq \mathbf{0},
\end{array}
$$

Where the change of notation from $u$ and $v$ to $\mu$ and $V$ is used to indicate that this is a different linear programming problem. The problem formulated in (2) is known as the multiplier form. Finally, we derive an equivalent envelopment by introducing the duality in linear programming:

$$
\begin{array}{rr}
\min _{\theta_{\mathrm{i}}, \lambda} \theta_{\mathrm{i}} & \\
\text { st } & -\mathbf{y}_{\mathbf{i}}+\mathbf{Y} \boldsymbol{\lambda} \geq \mathbf{0} \\
& \theta \mathbf{x}_{\mathbf{i}}-\mathbf{X} \boldsymbol{\lambda} \geq \mathbf{0}, \\
& \boldsymbol{\lambda} \geq \mathbf{0}
\end{array}
$$

Where $\lambda$ is a $I^{*} 1$ vector of constants, $\theta$ is a scalar and efficiency scores for the $i^{\text {th }}$ firm which satisfies: $\theta \leq 1$. Here $\theta$ is independent of input prices. 
Alternatively, one can estimate the cost and allocative efficiencies assuming variable return to scale (VRS) using DEA. This model allows the estimated production frontier to include increasing, decreasing or constant returns to scale properties. The constant returns to scale model described above is a special case of the VRS modeling. Following Coelli (1996), the cost minimization set up for the VRS model is

$$
\begin{aligned}
& \operatorname{Min} \lambda, \mathrm{x}_{\mathrm{i}}^{*} \mathbf{w}_{\mathrm{i}}^{*} \mathrm{x}_{\mathrm{i}}^{*} \\
& \text { st } \quad-\mathrm{y}_{\mathrm{i}}+\mathrm{Y} \lambda \geq 0 \\
& x_{i}^{*}-\mathrm{X} \lambda \geq 0, \\
& N 1^{\prime} \lambda=1, \\
& \lambda \geq 0
\end{aligned}
$$

Here, $w_{i}$ is a vector of input prices for the $\mathrm{i}^{\text {th }}$ farm and $x_{i}$ represents the vector of cost minimizing farm-input quantities for the $i^{\text {th }}$ farm (designed by DEA model). Then cost efficiency (CE), allocative efficiency (AE) and scale efficiency (SE) of $\mathrm{i}^{\text {th }}$ farm can be calculated as

$$
\begin{aligned}
& C E=\frac{w_{i}^{\prime} y_{i}^{*}}{w_{i}^{\prime} y_{i}} \\
& A E=\frac{C E}{T E} \text { and } \\
& S E=\frac{T E_{i, C R S}}{T E_{i, V R S}}
\end{aligned}
$$

Cost efficiency is the comparative amount of minimum cost to observed cost designed for the ith farm. Models presented above are related to variable returns to scale DEA. Scale efficiency (SE) can be estimated by removing the convexity constraint 
$\left(\left(N 1^{\prime} \lambda=1\right)\right.$ from equation 4 (Coelli, 1996). Values of SE closer to 1.0 indicate that SE operates near CRS and SE values less than one indicate inefficiency in VRS due to suboptimal scale.

Input oriented DEA models under the CRS assumption are widely used to solve overall technical efficiency (Charnes et al. 1994; Färe et al. 1994; Dhungana et al. 2004, Poudel et al. 2015). After attaining efficiency scores from Data Envelopment Analysis, the variation in efficiency scores were regressed on the socio-economic characteristics of the farming communities using a Tobit regression (Dhungana et al. 2010; Dhungana et al. 2004; Wadud and White, 2000; Poudel et al. 2015; Sharma et al. 1999; Wang et al. 1996; Hallam and Machado, 1996). Analysis using Tobit regression, to study efficiency and explore determinants of efficiency, has been increasingly cited in the literature. Rice farm efficiency were studied in Bangladesh (Coelli et al. (2002), in Indonesia (Brazdik, 2006), in Turkey (Tipi et al. 2009), in cotton production in Bangladesh (Sarkar et al. 2016), cotton farms of Pakista (Gul; 2009), in English Channel fisheries analysis (Tingley et al. 2005), and organic versus conventional coffee production efficiency comparison in Nepal (Poudel et al. 2015) using DEA approach and Tobit regression. Similarly, Tobit model as a second stage to determine the farm specific attributes in explaining inefficiency is suggested in a number of studies (Kalirajan 1991; Parikh and Shah 1995; Llewelyn and Williams 1996; Shafiq and Rehman 2000). Early methodologies were based on deterministic models that attribute all deviations from the maximum production to efficiency; recent advances have made it possible to separately account for factors beyond and within the control of firms such that only the latter will cause inefficiency. A 
Tobit model is suitable for estimating factors affecting efficiencies of the targeted samples as the efficiency scores vary from zero to unity by setting upper limit at one.

The Tobit model is a special case of a censored regression model, because the latent variable $T E_{i}^{*}$ cannot always be observed while the independent variable $X_{i}$ is observable. A Tobit model is suitable for estimating factors affecting the technical efficiency of surveyed farms. As the TE scores vary from 0 to 1; by setting upper limit at 1 the dependent variable is now characterized as;

$$
T E_{i}= \begin{cases}1 & \text { if } T E_{i}^{*}=1 \\ 0 & \text { otherwise }\end{cases}
$$

The functional form of the parameter estimation is $T E^{*}=\boldsymbol{Z} \boldsymbol{\beta}+\varepsilon . \mathbf{Z}$ stands for vector of socio-economic characteristics of the farms in the study area. $\boldsymbol{\beta}$ is a vector of unknown parameter and $\varepsilon_{i}$ is an independently and identically distributed normal random variables with zero means and common variance, $\sigma^{2}$ as; $\varepsilon_{\mathrm{i}} \sim \operatorname{iidN}\left(0, \sigma^{2}\right)$. The tobit model uses maximum likelihood estimate (MLE) to estimate both $\beta$ and $\sigma$ for this model. It is important to know that $\beta$ estimates the effect of $Z$ on $T E^{*}$, the latent variable, not TE (uncensored). The censored regression model described above is different than a truncated regression model. Truncated regression is used when rather than being censored, the data is missing beyond a censoring point (Green, 2017). Final estimated Tobit model is presented as:

$T E_{i}=\beta_{0}+\sum_{i=1}^{12} \beta_{i} Z_{i}+\varepsilon_{i}$ 
Where TE is the efficiency index from DEA converted to a binary dependent variable. $Z_{j}$, $\mathrm{j}=1, . ., 12$, represent: gender of the household head, age of the farm manager, education of the farm manager (household head),family size, resident area (rural or non-rural),distance to nearest creek, distance to forest area, land use change practice $(0=$ no, $1=$ yes $)$, farmer's access to agricultural extension programs $(0=$ no, $1=$ yes $)$, access to formal financial institution $(0=$ no, $1=$ yes $)$, electricity connection $(0=$ no, $1=$ yes $)$, and distance to market respectively.

The model assumes that there is an underlying, stochastic index equal to $(Z \beta+\varepsilon)$, which is observed only when it is less than 100 and, henceforth, qualifies as an unobserved, latent variable (Coelli et al. 2002; Dhungana et al. 2004). The dependent variable in the above given regression equation cannot have a normal distribution. It has a censored distribution, because its value lies between 0 and 100. Ordinary Least Squares estimation using a censored sample yields inconsistent estimates. Instead we estimate the Tobit regression model using the maximum likelihood approach (Tobin 1958). It is possible to show that the expected value is (Coelli et al. 2002; Dhungana et al. 2004),

$$
E(y \mid Z)=1-\Phi(b) \times 100+\Phi(b) Z \beta-\sigma \Phi(b)
$$

Where $b=(100-Z B) / \sigma$. Marginal effect for continuous explanatory variables such as age, education, family size and distance can be computed as $\frac{\partial E(y \mid Z)}{\partial Z_{k}}=\Phi(b) \beta_{k}$. Similarly, marginal effect for dummy variables $\left(\mathrm{Z}_{\mathrm{d}}\right)$ such as resident area, access to 
extension, access to credit etc) is calculated as $E\left(y \mid \mathrm{Z}_{d}\right)=100-E\left(y \mid \mathrm{Z}_{d}\right) \cdot \mathrm{Z}_{\mathrm{d}}$ stands for dummy variable.

These variables are important in explaining productivity of farming practices. Focus group discussions in the field revealed that the educated young generation is reluctant to take up farming as an occupation. On the other hand, illiterate farmers are less able to grasp modern farming knowhow. Respondents from rural areas show a negative effect on technical efficiency in the upriver region. Upriver farms are scattered and are located on steep slopes in the study area while downriver farms in the rural area are mostly governed by ethnic, marginal and ultra-poor peasants who have limited access to modern inputs. In the Tobit model, we expect educated and experienced farm manager are more efficient in input rationing and output management. Larger family size may have more members to work in the farm and help harvesting better output. Farms who have better access to a market center will procure agricultural inputs and able to sell their products on time. We expect that access to extension services will provide farmers with the information and technical assistance they need to make better farm management. Those farmers with more access to credit have a smaller financial barrier to invest in farm infrastructures and/or necessary durable assets that could enhance farm productivity. 


\section{Results and Discussions}

\subsection{Descriptive Statistics}

Table 1 reports the summary statistics of farm inputs, outputs and other relevant geographic and demographic variables. Farming units are small. The average farm in the downriver ecoregion is bigger than farms upriver. Farm output is more than double in the downriver region. The mean water usage in a farm during the production period is 7,525 and 14,035 liters in upriver and downriver respectively. Household heads are of similar age, around 49 years. Farms in the upriver and downriver regions are 2.91 and $4.22 \mathrm{~km}$ away from a river (tributary) and 0.74 and $0.78 \mathrm{~km}$ from creeks respectively. Farmers manage agricultural water from creeks that flow close to their farmland. However, water in tributaries is also important for the farming communities. Water in the upriver region is more expensive (Rs 0.1/ liter) that downriver (Rs. 0.07/liter). Cost differences in managing agricultural water are mostly due to the topographic hurdles in upriver areas (steep slope and extreme undulated mountain terrace). The average distance to a nearby market(s) for both input and output transaction are about similar, 6.32 and $6.5 \mathrm{~km}$ in upriver and down river farming communities respectively. Gross margin analysis of farms shows that upriver farms are performing relatively better than downriver farms. Though cropping intensity ${ }^{7}$ is higher on downriver farms because of tropical weather compared to upriver farms, the difference in gross margins is due to productivity and output market prices. Mean gross margin obtained in upriver and down river farms are

\footnotetext{
${ }^{7}$ Cropping intensity is the ratio of effective crop area harvested to the physical area. The cropping intensity may exceed $100 \%$ if more than one crop cycle is completed in a year on the same farmarea.
} 
53,880 and 50,000 respectively. The household survey found that $74.22 \%$ and $77.33 \%$ of household heads are male in the upriver and down river regions respectively. About 19\% and $20 \%$ household heads are illiterate and $78 \%$ and $86 \%$ households are residing in rural areas in upriver and down river along the Koshi river basin.

Table 1. Summary statistics of farm related variables in upriver-down river regions

\begin{tabular}{lllll}
\hline Variables & \multicolumn{3}{l}{ Upriver } & \multicolumn{2}{l}{ Downriver } \\
\cline { 2 - 5 } & Mean & SD & Mean & SD \\
\hline Farm output (Qtl) & 13.14 & 6.87 & 32.76 & 27.31 \\
Farm size (Ropani) & 12.90 & 5.67 & 21.80 & 14.18 \\
Labor (No. of worker in farm) & 77.06 & 33.17 & 113.56 & 72.91 \\
Capital (Rs/production period) & 10373.17 & 4465.40 & 15286.78 & 9815.45 \\
Water (liter per season) & 7525.50 & 8269.05 & 14035.63 & 14409.33 \\
Household head age (year) & 49.94 & 8.17 & 49.47 & 6.32 \\
Distance from the river (km) & 2.91 & 1.92 & 4.22 & 3.59 \\
Distance from creek (km) & 0.74 & 0.49 & 0.78 & 0.70 \\
Water cost for agricultural use (Rs/lit) & 0.10 & 0.25 & 0.07 & 0.11 \\
Distance to the water source (km) & 1.19 & 1.20 & 0.97 & 0.74 \\
Distance to the nearby market (km) & 6.32 & 2.40 & 6.50 & 3.52 \\
Gross margin (Rs'000) & 53.83 & 27.54 & 50 & 26.67 \\
\hline
\end{tabular}

Source: Field survey, 2015

\subsection{Technical, Allocative, Cost and Scale Efficiency}

Technical efficiency was estimated using DEAP software (2.1) version developed by Coelli (1996) and is presented in table 2 for both upriver and downriver farms in the Koshi river basin. Results show that TE ranges from 0.18 to 1.00 and 0.29 to 1.00 in the upriver and downriver regions respectively. When TE gets closer to one, the farm is 
considered more technically efficient. Mean technical efficiency scores are 0.59 and 0.66 in upriver and downriver respectively. This suggests that sample farms in upriver and downriver could potentially reduce their inputs for cereal crop production on average by $41 \%$ and $34 \%$ while still achieving the same level of output (the peer average) using existing technology. About $36 \%$ of the farms upriver and $53 \%$ downriver are operating below 0.5 TE. DEA for both constant returns to scale (CRS) and decreasing returns to scale (DRS) assumptions generates TE score in the same direction but of slightly different magnitudes. From VRS DEA it is observed that about $31 \%$ and $12 \%$ farms are unable to possess even 50\% technical efficiency in the upriver and downriver. Mean TE of the farms in upriver and downriver are 0.63 and 0.75 under the VRS DEA respectively. This implies that farms in upriver and downriver regions could produce the same level of output while reducing variable inputs an average $37 \%$ and $25 \%$. The median technical efficiency values were 0.606 and 0.756 for upriver and downriver farms respectively. From TE scores corresponding to median value, it is observed that about $76 \%$ of upriver farmers and $52 \%$ of downriver farmers are below median TE score. 
Table 2. Distribution of Technical Efficiency under CRS and VRS data envelopment analysis

\begin{tabular}{lllll}
\hline \multirow{2}{*}{$\begin{array}{l}\text { Efficiency } \\
\text { level }\end{array}$} & \multicolumn{2}{l}{ Constant Return to Scale DEA } & \multicolumn{2}{l}{ Variable Return to Scale DEA } \\
\cline { 2 - 5 } & Upriver & Downriver & Upriver & Downriver \\
\hline$<0.5$ & $80(35.56)$ & $53(23.56)$ & $68(30.22)$ & $26(11.56)$ \\
$0.5-0.59$ & $30(13.33)$ & $14(6.22)$ & $36(16)$ & $15(6.67)$ \\
$0.6-0.69$ & $40(17.78)$ & $24(10.67)$ & $29(12.89)$ & $30(13.33)$ \\
$0.7-0.89$ & $43(19.11)$ & $55(24.44)$ & $37(16.44)$ & $60(26.67)$ \\
$0.8-0.89$ & $20(8.89)$ & $47(20.89)$ & $27(12)$ & $43(19.11)$ \\
$0.9-1$ & $12(5.33)$ & $32(14.22$ & $28(12.44)$ & $51(22.67)$ \\
\hline Grand Total & $225(100)$ & $225(100)$ & $225(100)$ & $225(100)$ \\
\hline Mean & 0.594 & 0.666 & 0.639 & 0.751 \\
Max. & 1 & 1 & 1 & 1 \\
Min. & 0.183 & 0.078 & 0.208 & 0.290 \\
STD & 0.25 & 0.25 & 0.207 & 0.180 \\
\hline
\end{tabular}

Source: Field Survey, 2015. Value in the parenthesis indicates percentage

Table 3. Distribution of farms according to return to scale

\begin{tabular}{lll}
\hline Return to Scale & Upriver & Downriver \\
\hline Decreasing Return to Scale(DRS) & $46(20.44)$ & $32(14.22)$ \\
Increasing Return to Scale(IRS) & $170(75.56)$ & $185(82.22)$ \\
Constant Return to Scale (CRS) & $9(4)$ & $8(3.56)$ \\
Total farms & $225(100)$ & $225(100)$ \\
\hline
\end{tabular}

Source: Field Survey, 2015. Value in the parenthesis indicates percentage

Farms operating under CRS, DRS and IRS represent $20.44 \%, 75.57 \%$ and $4 \%$ of upriver farms, and $14.22 \%, 82.22 \%$ and $3.56 \%$ of downriver farms respectively (Table 3). In both regions, more than two-thirds of the farms are operating under increasing returns to scale and are yet to achieve the maximum physical product. From the input 
management point of view, 20.44\% farms in upriver and $14.22 \%$ farms in downriver appear to be overusing their farm resources. However, there might be some socioeconomic variables exerting pressure to scale back. The average farm output in the various categories of $\mathrm{TE}$ and $\mathrm{AE}$ are presented in the figure 4 and 5 respectively.

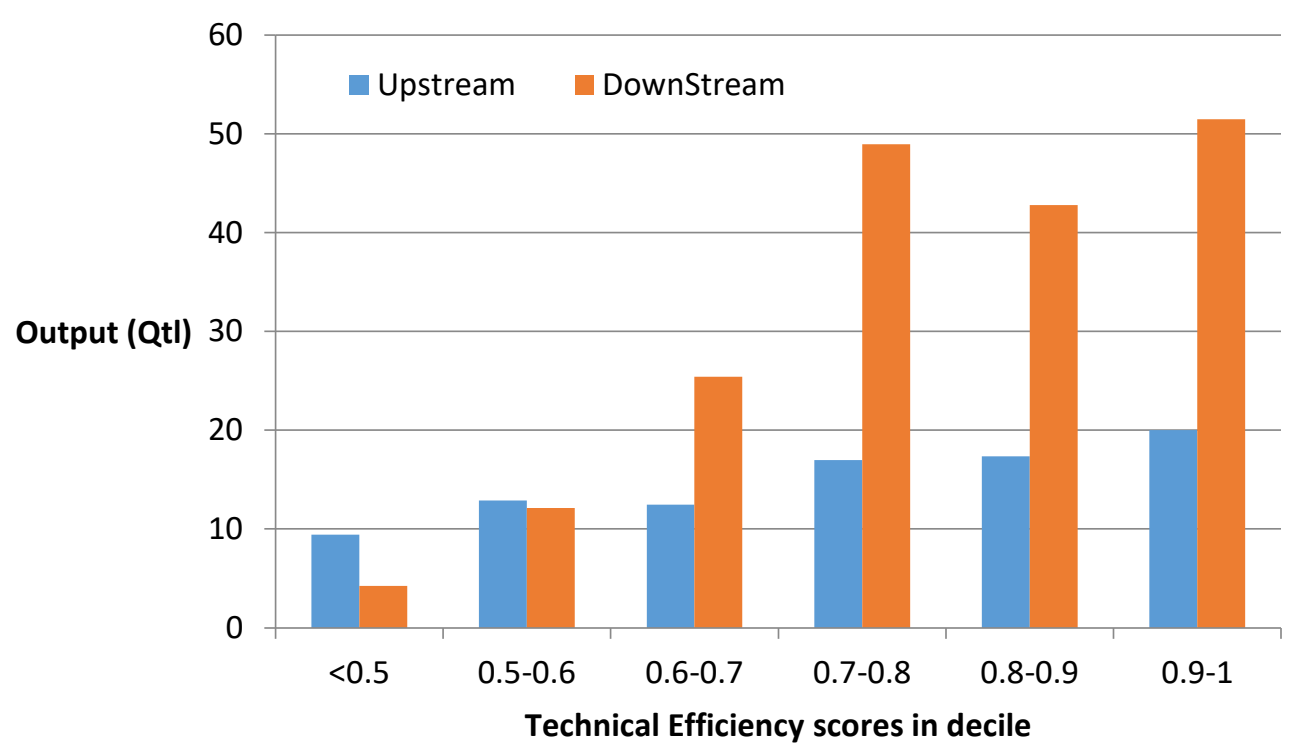

Figure 4. Output produced in different categories of TE Source: Filed Survey, 2015

Note: 1 Qtl= $100 \mathrm{Kg}$ 


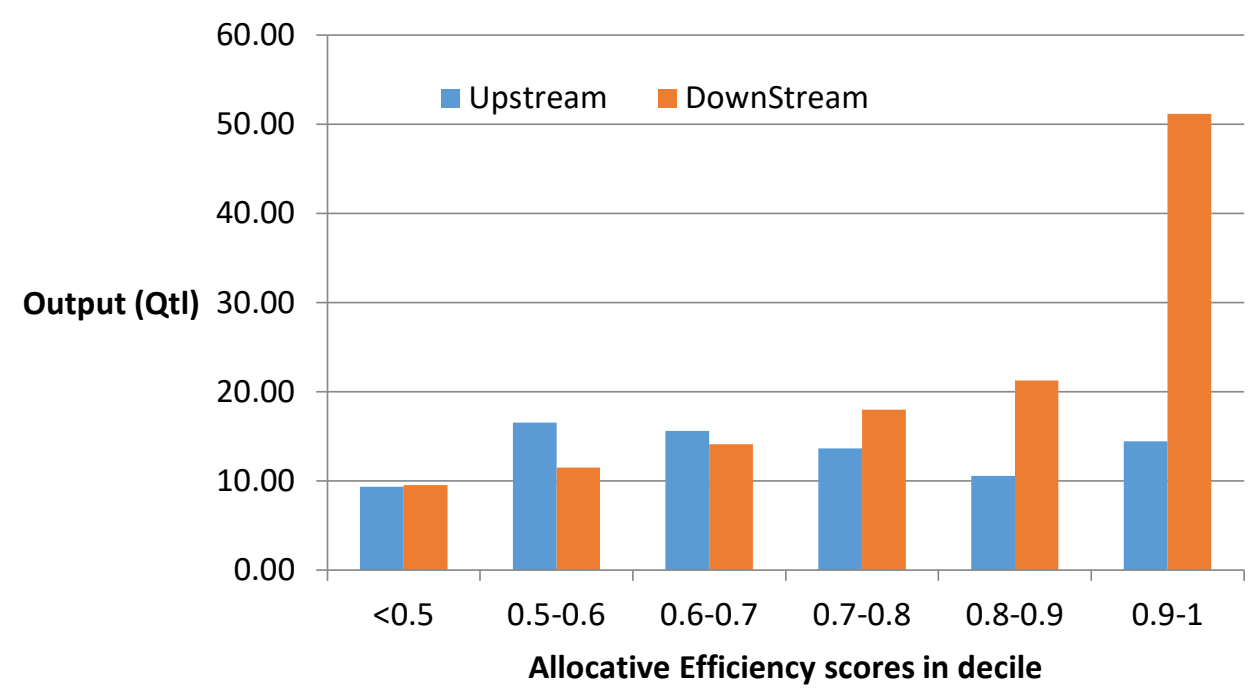

Figure 5. Output produced under different categories of AE Source: Filed Survey, 2015

Only about 35 farms in both upriver and downriver are operating with TE equal to 1.0. From table 4 it is observed that about $37 \%$ of upriver farms and $44 \%$ of downriver farms are allocatively efficient and with a mean $\mathrm{AE}$ greater than 0.8 in both the regions. Only two farms $(0.89 \%)$ in upriver and $5.33 \%$ farms in downriver are cost efficient with mean CE 0.47 and 0.57 respectively. About $79 \%$ and $81 \%$ farms in downriver and upriver operates close to constant return to scale respectively. 
Table 4. Allocative, Cost and Scale efficiency in upriver and downriver

\begin{tabular}{lllllll}
\hline \multirow{2}{*}{$\begin{array}{l}\text { Efficiency } \\
\text { Level }\end{array}$} & \multicolumn{2}{l}{ Allocative Efficiency } & \multicolumn{2}{l}{ Cost Efficiency } & \multicolumn{2}{l}{ Scale Efficiency } \\
\cline { 2 - 7 } & Upriver & Downriver & Upriver & Downriver & Upriver & Downriver \\
\hline$<0.5$ & $15(6.67)$ & $2(0.89)$ & $123(54.67)$ & $75(33.33)$ & $0(0)$ & $29(12.89)$ \\
$0.5-0.59$ & $16(7.11)$ & $1(0.44)$ & $47(20.89)$ & $21(9.33)$ & $0(0)$ & $0(0)$ \\
$0.6-0.69$ & $25(11.11)$ & $26(11.56)$ & $38(16.89)$ & $34(15.11)$ & $8(3.56)$ & $0(0)$ \\
$0.7-0.89$ & $18(8.00)$ & $37(16.44)$ & $10(4.44)$ & $59(26.22)$ & $12(5.33)$ & $4(1.78)$ \\
$0.8-0.89$ & $68(30.22)$ & $61(27.11)$ & $5(2.22)$ & $24(10.67)$ & $22(9.78)$ & $15(6.67)$ \\
$0.9-1$ & $83(36.89)$ & $98(43.56)$ & $2(0.89)$ & $12(5.33)$ & $183(81.33)$ & $177(78.67)$ \\
Grand & $225(100)$ & $225(100)$ & $225(100)$ & $225(100)$ & $225(100)$ & $225(100)$ \\
Total & & & & & & \\
\hline Mean & 0.815 & 0.859 & 0.475 & 0.578 & 0.933 & 0.838 \\
Max. & 1 & 1 & 1 & 1 & 1 & 1 \\
Min. & 0.302 & 0.379 & 0.114 & 0.073 & 0.601 & 0 \\
STD & 0.154 & 0.121 & 0.168 & 0.243 & 0.082 & 0.326 \\
\hline Source: & & & & & & 1 \\
\hline
\end{tabular}

Source: Field Survey, 2015. Value in the parenthesis indicates percentage

\subsection{Factors Affecting Technical Efficiency}

Technical efficiency (TE) scores obtained from DEA approach are now censored as 1 (upper limit), 0 otherwise. The Tobit regression model defined in equation 8 is estimated separately for upriver and downriver regions. The results of the Tobit regressions are presented below (Table 5). 
Table 5. Determinants of Technical inefficiency in upriver and downriver farming communities

\begin{tabular}{|c|c|c|c|c|c|c|}
\hline \multirow[t]{2}{*}{ Variables } & \multicolumn{4}{|c|}{ Upriver $(\mathrm{n}=225)$} & \multicolumn{2}{|c|}{ Downriver $(\mathrm{n}=225)$} \\
\hline & Coef. & $\mathrm{t}$ value & $\mathbf{P}>\mathbf{t}$ & Coef. & $\mathrm{t}$ value & $\mathrm{P}>\mathrm{t}$ \\
\hline Gender & 0.0277 & 0.99 & 0.324 & -0.0189 & -0.59 & 0.556 \\
\hline Age & 0.0028 & 2.02 & 0.045 & 0.0031 & 1.36 & 0.175 \\
\hline Education & 0.0604 & 1.83 & 0.069 & -0.1287 & -3.11 & 0.002 \\
\hline Household size & -0.0083 & -0.64 & 0.522 & -0.0136 & -0.8 & 0.423 \\
\hline Residence & -0.1064 & -3.52 & 0.001 & -0.0374 & -0.72 & 0.473 \\
\hline Distance to creek & 0.1630 & 5.45 & 0.000 & 0.1546 & 7.14 & 0.000 \\
\hline Distance to forest & 0.0655 & 4.35 & 0.000 & 0.0066 & 1.71 & 0.089 \\
\hline Land use change & 0.1455 & 5.08 & 0.000 & -0.1198 & -3.37 & 0.001 \\
\hline Extension & 0.0423 & 1.22 & 0.223 & 0.0162 & 0.39 & 0.701 \\
\hline Credit access & 0.0090 & 0.39 & 0.000 & 0.0483 & 1.02 & 0.000 \\
\hline Electricity access & -0.0563 & -2.2 & 0.029 & 0.3169 & 6.2 & 0.000 \\
\hline $\begin{array}{l}\text { Distance to } \\
\text { market }\end{array}$ & 0.0068 & 1.2 & 0.231 & 0.0275 & 4.95 & 0.000 \\
\hline Constant & 0.5329 & 5.19 & 0.000 & 0.2220 & 1.61 & 0.109 \\
\hline Prob. $>\mathrm{Chi}^{2}$ & & .0000 & & & & \\
\hline Pseudo $\mathrm{R}^{2}$ & & 1.1165 & & & & \\
\hline Log Likelihood & & 33.8892 & & & & \\
\hline
\end{tabular}

Source: Field survey, 2015

Table 7 indicates that distance to agricultural water source(s), land use change practices, access to public agricultural extension services, access to agricultural credit from formal financial institutions, and distance of market centers for both inputs and outputs are statistically significant in both upriver and downriver regions of the Koshi river basin. As expected, experienced farm managers contribute to greater technical efficiency in both regions. However, the age of the household head is positive and 
significant only in the upriver region. Interestingly, education has a negative impact on efficiency in downriver while it is positive for upriver. Educated farmers in the downriver have a multitude of opportunities to improve their earnings which may lead them to devote less attention to their farms.

Normally, one would hypothesize that experienced farmers should have more skills in allocating scarce farm resources and positively impact technical efficiency. Experienced farmers are able to reduce water leakages, apply prior knowledge in production planning, use local knowledge for plant protection measures, and be able to implement climate change adaptation measures. Educated and experienced farmers were seen practicing water saving methods such as drip irrigation, mulching, plastic sheet covers over porous and sandy soils and rain-water traps in plastic pond in the upriver region. These practices are rarely seen downriver. Despite the observation that many big farms are left fallow because of farm labor shortage, family size is not significant in either region. Until recently, even large households could not procure sufficient on-farm labor since high school graduates were hesitant to work on farms.

Most of the farmers in the river basin procure agricultural water from local creeks/tributaries (mostly perennial). Distance between sources to sites (farms) is another significant $(\mathrm{P}<.0001)$ factor explaining technical efficiency in both upriver and downriver farming communities. Farmers indicate that the shorter the distance, the better 
the water conveyance efficiency ${ }^{8}$. Given similar source-to-site distances, water conveyance efficiency is higher in the downriver (plain area) compared to upriver (hill and mountain area). Less water loss in- route to farms contribute to more water available during the cropping season which tends to allow higher cropping intensity ${ }^{9}$. It also reduces the costs of farm operation. Similarly, any farms near forest areas are relatively more efficient than their peers. Distance to forest area from the farmland has a significant and positive impact in both regions of the river basin. It may be due to microclimatic moderation and farms receiving more precipitation and less temperature fluctuations.

The Government of Nepal (GON) and several international agricultural development programs believe that extension services (mostly government and also semigovernment, non-government and private sectors) could act as drivers of change in technology dissemination and complete feedback process. Extension services including on-farm demonstration, trade-fair and plant protection clinics are deemed important to disseminate agricultural technology such as agronomic practices, post-harvest and marketing management (MOAD, 2014). This variable is specifically important to marginal and small holders in all regions. Demonstration and agronomic methods and their results are commonly used approaches to motivate and engage farmers in

\footnotetext{
${ }^{8}$ Irrigators normally deliver the water from its source to the crop area through natural drainage (earthen or lined canals). Water loss between the source and at-site is unavoidable because of seepage, spills, evaporation, leaks, etc. Conveyance efficiency can be estimated as the ratio of the net amount of water at-site to amount of water diverted at-source.

${ }^{9}$ Cropping intensity is the ratio of effective crop area harvested to the physical area. The cropping intensity may exceed 100 percent if more than one crop cycle is completed in a year on the same farmarea.
} 
agricultural enterprises. Surprisingly, the impact of extension services was not found significant in either regions although it has a positive coefficient. This may because the extension service package provided to the farmers has not been effective of adequate quality to make a significant contribution to efficiency.

Credit availability from formal financial institutions has been a recent process (less than a decade) for smallholders in rural areas of the river basin. Access to credit motivates and empowers farmers to undertake better production planning. Results show a positive and significant impact of credit access on both upriver and downriver farms. Most of the marginal and small holders are unable to invest in water saving infrastructure, for example. Dolisca and Curtis (2008) and Sarkar and Alam (2016) observed similar results while studying farming practices in Haiti and Cotton production in Bangladesh respectively. Farmers who had access to credit were more technically and economically efficient than who had no such access.

Many rural households are not connected to electricity in the upriver area. Electricity is important for pumping water from creeks or wells. The coefficient for the variable 'access to electricity' is positive and significant downriver but not upriver. Production units away from the market centers are relatively less efficient than the farms closer to the market centers. Markets signal demand based production and improve the economies of scale. Distance to market is positive and highly significant $((\mathrm{P}<.0001)$ in both upriver and downriver sections of the Koshi river basin. 


\section{Essay Summary and Policy Recommendations}

In a country where more than $65 \%$ of the population relies on agriculture for their livelihood, enhancing agricultural productivity and farm resource use efficiency is crucial for overall development. Every agricultural development plan highlights water resources as one of the prime factors needed to achieve accelerated agricultural growth. Unfortunately, productivity and agricultural value addition in both regions have not witnessed much improvement over the decades. The analysis here estimates that about $79 \%$ of farms are operating under increasing returns to scale meaning that they still have an opportunity to increase productivity by enlarging. Unreliable water supply hinders better production planning. Decreasing water flows in the creeks and declining flows from springs due to climate change are commonplace in the upriver region. This is exacerbated by deforestation in the region. The downriver region encounters erratic monsoon rain, flooding, and severe drought during the production cycle.

The results of this analysis reveal that the sample of farms in this study can potentially reduce their inputs for cereal crop production on average by $41 \%$ and $34 \%$. This would be possible due to access to credit, marketing management and the use of water saving technologies. About $36 \%$ of farms in the upriver and $53 \%$ in the downriver region are operating below 0.5 TE. Farms in this region require an integrated development package to improve their farming practices. Current technology is sufficient to make big gains in the productivity. A majority of the farmers believe that reliable water availability and market facilities can increase the efficiency of farming 
communities in both upriver and downriver sections of the Koshi river basin. Reliable water source revitalization via green infrastructure development (forestation, wetland protection) and community based source water management should be considered in future research.

\section{References}

Ali, M. and Flinn, J. C. 1989. Profit efficiency among Basmati rice producers in Pakistan Punjab. American Journal of Agricultural Economics, 71: 303-310.

Ali, M. and M. A. Chaudhary. 1990. Inter-regional farm efficiency in Pakistan Punjab: A frontier production function study. J. Agric. Econ., 41: 62-74.

Belbase, K., Grabowski, R. 1985. Technical efficiency in Nepalese agriculture. Journal of Development Areas, 19(4): 515-525.

Bravo-Ureta B. E. and Reiger L. 1991. Dairy Farm Efficiency measurement using Stochastic Frontier and Neoclassical duality. American Journal of Agricultural Economics, 73: 421-428.

Bravo-Ureta, B. E. and Pinheiro, A. E. 1997. Technical, economic and allocative efficiency in peasant farming: evidence from the Dominican Republic. The Developing Economics, XXXV (1): 48-67.

Brazdik, F. 2006. Non-parametric analysis of technical efficiency: Factors affecting efficiency of west java rice farms. Center for Economic Research and Graduate Education, Charles University, Working Paper Series. 
Charnes, A., Cooper W., Lewin, A.Y. and Seiford, L.M. 1994. Data Enveleopment Analysis: Theory, Methodology and Application, Kulwer Academic Publishers, Boston.

Coelli, T. J., Rahman S. and Thirtle C. 2002. Technical, allocative, cost and scale efficiencies in Bangladesh rice cultivation: a non-parametric approach. Journal of Agricultural Economics, 83: 607-626.

Coelli T. J. 1996. A guide to DEAP Version 2.1: a data envelopment analysis (computer) program. CEPA Working Paper 96/08, Department of Econometrics, University of New England, Armidale, Australia.

Coelli. T. J., D. S. P. Rao., C. J. O’Donnel and G. E. Battese. 2005. An Introduction to Efficiency and Productivity Analysis. Second Edition. Springer.

De Janvry, A., M. Fafchamps and E. Sadoulet. 1991. Peasant household behaviour with missing markets: Some paradoxes explained. Econ. Journal, 101: 14001417.

Dhungana B. R., Peter L. Nuthal and G.V. Nartea. 2004. Measuring the economic efficiency of Nepalese rice farms using data envelopment analysis. The Australian Journal of Agricultural and Resource Economics, 48(2): 347-369.

Dhungana B., Y. Sugimoto., N. Yamamoto and H. Kano. 2010. Technical Efficiency Analysis of Vegetable Farms in the Mid-hill Region of Nepal-An Approach Using Data Envelopment Analysis. Japanese Journal of Food, Agricultural and Resource Economics, 60(2): 27-37. 
Dolisca F. and Curtis, M. J. 2008. Technical efficiency of traditional and nontraditional crop production: A case study from Haiti. World Journal of Agricultural Sciences, 4:416-426.

Ellis, F. 1993. Peasant Economics: Farm households and agrarian development. $2^{\text {nd }}$ Edition. Cambridge University Press.

Eriksson, M.; Xu, J.; Shrestha, A. B.; Vaidya, R. A.; Nepal, S. and Sandstörm, K. 2009. The Changing Himalayas: Impact of climate change on water resources and livelihoods in the greater Himalayas. Perspectives on water and climate change adaptation. ICIMOD, Kathmandu.

Färe, R. and C. A. K. Lovell. 1978. Measuring the Technical Efficiency of Production. Journal of Economic Theory, 19:150-162.

Färe, R., S. S. Grosskorf., and C. A. K. Lovell. 1994. Production Frontiers. Cambridge University Press, Cambridge.

Farrell, M. J. 1957. The Measurement of Productive Efficiency. Journal of the Royal Statistical Society, 20(3):253-290.

Green, H. W. 2017. Econometric Analysis. Pearson, $8^{\text {th }}$ edition.

Gul M., Koc B., Dagistan M., Parlakay O. 2009. Determination of technical efficiency in cotton growing farms in Turkey: a case study of Cukurova region. Afr. J. Agric. Res. 4 (10): 944-949.

Hallam, D. and Machado, F. 1996. Efficiency analysis with panel data: a study of Portuguese dairy farms. European Review of Agricultural Economics, 12: 79-93. 
Hayami, Y. and V. Ruttan. 1985. Agricultural Development: An International Perspective. 1st Edn. Johns Hopkins University Press, Baltimore, pp: 506.

Hoff, A. 2007. Second stage DEA: Comparison of approaches for modelling the DEA scores. European Journal of Operational Research, 181: 425-435.

Idiong, I. C. 2007. Estimation of Farm Level Technical Efficiency in Small Scale Swamp Rice Production in Cross River Site of Nigeria: A Stochastic Frontier Approach. World Journal of Agricultural Sciences, 3(5): 653-658.

Inoni, O. E. and P. C. Ike. 2006. Determinants of Yam Production and Economic Efficiency Among Small-Holder Farmers in Southern Nigeria. Journal of Central European Agriculture, 7(2): 337-342.

Johnston, B. and J. Mellor. 1961. The role of agriculture in economic development. American Economic Review, 51: 566-593.

Kalirajan, K. P. 1991. The importance of efficient use in the adoption of technology: a macro panel data analysis. Journal of Production Analysis, 2: 113-126.

Lanker, S., S. Von Cramon-Taubadel and B. Brumer. 2012. Technical efficiency of organic pasture farming in Germany: The role of location economics and of specific knowledge. Renewable Agriculture and Food Systems, 27: 228-241.

Llewelyn, R.V. and Williams, J. R. 1996. Non-parametric analysis of technical, pure technical and scale efficiencies for food crop production in East Java, Indonesia. Journal of Agricultural Economics, 15:113-126. 
MCDonald, J. 2009. Using least squares and tobit in second stage DEA efficiency analyses. European Journal of Operational Research, 197:792-798.

Mekonnen E., Geta E. and Legesse, B. 2015. Production Efficiency of Sesame in Selamago District of South Omo Zone, Southern Ethiopia. Journal of Current Research in Agricultural Science, 2(1):8-21.

Mendola, M. 2007. Farm household production theories: A review of institutional and behavioral response. Asian Development Review, 24: 49-68.

Paudel, B., Zhang, Y., Li, S., Liu, L., Wu, X. and Khanal, N.R. 2016. Review of studies on land use and land cover change in Nepal. J. Mountain Science, 13: 643-660.

Parikh, A., Ali, F. and Shah, M. K. 1995. Measurement of economic efficiency in Pakistani agriculture. American Journal of Agricultural Economics, 77: 675-685.

Poudel, K. L., T. G. Johnson, N. Yamamoto, S. Gautam and B. Mishra. 2015. Comparing technical efficiency of organic and conventional coffee farms in rural hill region of Nepal using data envelopment analysis (DEA) approach. Organic Agriculture, 5: 263-275.

Rahman, S. 2010. Women's labour contribution to productivity and efficiency in agriculture: Empirical evidence from Bangladesh. J. Agric. Econ., 61: 318-342.

Rahman, S., A. Wiboonpongse, S. Sriboonchitta and Y. Chaovnapoonphol, 2008. Production efficiency of Jasmine rice producers in Northern and North-Eastern Thailand. J. Agric. Econ., 60: 419-435.

Ray, S. C. 2004. Data Envelopment Analysis: Theory and Techniques for Economics and Operations Research. New York: Cambridge University Press. 
Sarker, J. R. and M. F. Alam. 2016. Efficiency and economics in cotton production of Bangladesh. Journal of Agriculture and Environment for International Development, 110 (2): 325-348.

Schultz, T.W. 1964. Transforming Traditional Agriculture. 1st Edn., Yale University Press, New Haven, ISBN: 9780226740751.

Shafiq, M. and Rehman, T. 2000. The extent of resource use inefficiencies in cotton production in Pakistan's Punjab: an application of data envelopment analysis. Agricultural Economics, 22: 321-330.

Sharma, K. R., Leung, P. and Zalleski, H. M. 1999. Technical, allocative, and economic efficiencies in swine production in Hawaii: a comparison of parametric and non-parametric approaches. Agricultural Economics, 20: 23-35.

Squires, D. and Tabor, S. 1991. Technical efficiency and future production gains in Indonesia agriculture. The Developing Economics, 29: 258-270.

Tadessea, B. and S. Krishnamoorthy, 1997. Technical efficiency in paddy farms of Tamil Nadu: An Analysis based on farm size and ecological zone. J. Agric. Econ., 16: 185-192.

Tingley D., Pascoe S. and Coglan L. 2005. Factors affecting technical efficiency in fisheries: stochastic production frontier versus data envelopment analysis approaches. Fisheries Research, 73:363-376.

Tipi T., Yildiz N., Nargelecekenler M. and Cetin B. 2009. Measuring The Technical Efficiency and Determinants of Efficiency of Rice (Oryza Sativa) Farms in 
Marmara Region, Turkey. New Zealand Journal of Crop and Horticultural Science, 37: 121-129.

Tobin, J. 1958. Estimation of Relationship for limited dependent variables. Econometrica, 26:26-36.

Wadud, A. and White, B. 2000. Farm household efficiency in Bangladesh: a comparison stochastic frontier and DEA methods. Applied Economics, 32: 1665-1673.

Wang, J., Cramer, G. L., and Wailes, E. J. 1996. A shadow price frontier measurement of profit efficiency in Chinese agriculture. American Journal of Agricultural Economics, 78: 46-156.

WECS. 2011. National water plan. Kathmandu: His Majesty's Government of Nepal, Water and Energy Commission Secretariat (WECS). Kathmandu, Nepal.

Xu, X. and Jeffrey, S. R. 1998. Efficiency and technical progress in traditional and modern agriculture: evidence from rice production in China. Agricultural Economics, 18: $157-165$. 


\section{ESSAY 2: Determinants of Water Resource Adaptation in Nepal: a Logistic Regression Analysis}

\section{Research Problem and Rationale of the Study}

Climate change is posing a serious threat to both low and high income countries. It threatens both assets such as ground water, forestry, livestock, wildlife, and permafrost and social issues such as food security, migration, land-use patterns, tourism, and culture. Panta (2012) finds that a rise in minimum temperature decreases the productivity of rice by reducing the water availability in the paddy fields. This poses a great threat to food security especially in the Hill and Terai regions of Nepal. Analysis of Nepalese agriculture shows that climate variables have a significant impact on the net farm income per unit of land (Thapa and Joshi, 2010). It will also have important income distribution implications. Conceição and Zhang (2010) conclude that the effects of climate change in tropical regions will be overwhelmingly negative.

Scientists and other concerned individuals have stressed the need for adaptations to changing water availability. Developing countries like Nepal have had insufficient capacity to assess and plan for climate change, and its consequences for water resources in various ecologies. Awareness of the issues by the public continues to rise but awareness alone is not sufficient to protect the human and ecological assets in the region. The consequences of climate change in the Himalayan region are particularly critical owing to the large proportion of the population depending on climate-sensitive 
agriculture (Pradhan et al., 2012). Enhancing resilience of families, businesses and communities requires research-based adaptation strategies designed within the context of development plans.

The rationale for the current research is that by identifying early changes in conditions faced by small hold farmers, and by identifying key vulnerabilities, we may anticipate some of the most fruitful intervention points for researchers and policy makers. Furthermore, by identifying current responses of small holders to these changes, and by documenting the consequences of the responses, we might develop better strategies for longer term adaptation to changing conditions.

\section{Research Questions}

The central research question is to determine the factors that lead to adaptive behavior of the farmers in three ecological regions (Mountain, Hill and Terai) of Nepal. In addition, this survey tried to assess how changing climatic variability is impacting the seasonal availability of water resources and the consequences of these changes for small scale agricultural producers in three ecological regions of Nepal.

\section{Objectives}

The broad objective of the research is to explore economically and environmentally sustainable water resource adaptation management strategies for rural 
communities in the Himalayan region of Nepal. The working objective is to collect and analyze adaptation strategies on water resource management in agriculture.

\section{Hypothesis}

Followings are the hypotheses tested in the current research:

$\checkmark$ There are discernable effects of climate change on water resource availability and on major food crop production in the three ecologies of Nepal.

$\checkmark$ Socio-cultural values and local institutions are relevant in climate change adaptation to water resource management.

\section{Literature Review}

Rising average temperatures affect crop and livestock production by altering insect-pests and diseases, soil metabolic processes, soil water content (Liverman, 2008; Sinha, 1997), biotic and abiotic stresses, and altered soil nutrient cycling (Chaudhari and Aryal, 2009; Schiermeier, 2008; Howden et al., 2007). The resulting changes in crop yields, costs and revenues have consequences for income redistribution and livelihood security of farming communities (Lettenmaier et al., 1994). Many, but not all studies project negative consequences - some studies have shown positive impacts of climate change in some ecosystems (Khanal, 2009; Malla, 2008; Polley, 2002). Increased $\mathrm{CO}_{2}$ concentration and higher temperatures can improve water-use efficiency of crops. Higher temperatures favor higher biomass production (Polley, 2002) and increase the possibility 
of expanding and diversifying agriculture (Khanal, 2009) at higher altitudes. However, it is hard to predict the physiological responses of crops to altitudinal differences (Rosenzweig and Hillel, 1995). Some prominent research on climate risks and adaptation measures taken in response to changing water resources are presented in table 1.

Table. 1 Climate risks and adaptation measures to water resources

\begin{tabular}{|c|c|c|}
\hline Risks & Adaptation measures & References \\
\hline \multirow{4}{*}{ Flood } & $\begin{array}{l}\text { Structural dykes, weirs, and other engineering } \\
\text { infrastructure }\end{array}$ & $\begin{array}{l}\text { Kuntiyawichai et al. (2010); Hoa et } \\
\text { al. (2007) }\end{array}$ \\
\hline & Flood forecasting & Plate (2007) \\
\hline & Insurance: flood prone crops, property and lives & $\begin{array}{l}\text { Smit and Skinner(2002); Naess et } \\
\text { al. (2005); Dawson et al. (2011) }\end{array}$ \\
\hline & $\begin{array}{l}\text { Institutional arrangements and governance (local } \\
\text { communities and management right- use right) }\end{array}$ & Bastakoti et al.(2014) \\
\hline \multirow[t]{3}{*}{ Drought } & $\begin{array}{l}\text { Water resource management (reservoirs, seasonal } \\
\text { water harvest ponds and irrigation infrastructure) }\end{array}$ & $\begin{array}{l}\text { Turral et al. (2010); Rossi et al. } \\
\text { (2005), Paudel et al. (2014) }\end{array}$ \\
\hline & $\begin{array}{l}\text { Adapting improved water harvesting techniques } \\
\text { and irrigation efficiency measures }\end{array}$ & Ngigi et al. (2000) \\
\hline & Drought resistant cultivars & $\begin{array}{l}\text { Fukai et al. (1999); Hall (2004); } \\
\text { Jongdee et al.(2006); Chhetri and } \\
\text { Easterling (2010) }\end{array}$ \\
\hline $\begin{array}{l}\text { Wet } \\
\text { landslide }\end{array}$ & Land use change (to maintain slope stability) & $\begin{array}{l}\text { Collison et al. (2000); Crozier } \\
(2010)\end{array}$ \\
\hline $\begin{array}{l}\text { Intense } \\
\text { rain }\end{array}$ & $\begin{array}{l}\text { Site specific vegetation to maintain slope and } \\
\text { infiltration }\end{array}$ & Wilkinson et al. (2002) \\
\hline
\end{tabular}

Spatial and temporal analysis is important for effective policy formulation related to both adaptation to, and mitigation of, water resource vulnerability. The geographic conditions and production specialization of regions are major factors explaining economic vulnerability of a region's residents (Porfir'ev, 2011); both are critically related to water availability and water use. When faced with changing conditions, households, 
farms, businesses and communities must either accept the resulting loss of income, wealth and security or take steps to reduce their effects by investing in adaptation strategies now and reducing those anticipated losses in the future. Conceição and Zhang (2010) frame this as a benefit-cost analysis in which avoiding future losses from climate change are benefits while current incomes foregone to receive those future benefits are costs. This sort of climate change analysis addresses the issues of trade-offs across generations.

Despite the enormous potential and feasibility of developing water resources (Pradhan et al., 2012; Eriksson et al., 2011; WESC, 2011), only a fraction of these water resources are being utilized in some regions while in other regions (the Hill region especially) there is a serious shortage of surface water and significant depletion of ground water (especially in the plain region) (WECS, 2011). The uneven availability of water resources has already started to impact the economy, biodiversity, environmental amenities and agricultural sector. Social ethnic groups (Bote, Majhi and Tharu ) who have traditionally relied on water bodies to harvest fish and other aquatic creatures to sustain their life are facing substantial reductions in harvests and have largely shifted to other jobs (Kafle and Dahal, 2014). Degraded water quality and sharp fluctuations in river flows are clear evidence for these changes. At the same time, flooding during the rainy season and drought in the winter and summer jeopardize smallholder agriculture. In addition to drought, the flash-floods, landslides (long arid periods followed by intense rainfall) and changing of river courses are prominent problems in the Hill region. 
Nepal is increasingly experiencing climate hazards that impact a large section of the population and their economic bases (Table 2). Decreased snowfall leads to loss of grazing capacity (Paudel et al. 2014; Khanal, 2009; Chaudhari and Aryal, 2009), avalanches, glacier lake outbreaks and other disruptions to the normal livelihood of mountain people (WESC, 2011).

Table 2. Climate hazards statistics in Nepal (1971-2011)

\begin{tabular}{lll}
\hline Events & No. of events & Affected Population \\
\hline Flood & 2,720 & $3,367,974$ \\
Drought & 152 & 15120 \\
Intense rain & 187 & 62,431 \\
Hail storm & 597 & 197,843 \\
\hline
\end{tabular}

Source: DesInventor Database, 2013

Access on Dec.10, 2014 at http://www.desinventar.net/DesInventar/main.jsp?countrycode=g13

Assessment of past and expected future precipitation patterns and their vulnerability at different timescales is necessary to understand the impact of climate change on hydrology (Menzel et al., 2006; Yaning et al., 2006), water resource management (Risby and Entekhabi, 1996; Kabat and van Schaik, 2003), agriculture (Darwin et al., 1995; Adams et al., 1998; Selvaraju, 2003), floods (Mirza et al., 1998; Reynard et al.,1998; Miller et al., 2004), droughts (Vicente-Serrano and Lopez-Moreno, 2006), soil erosion (Valentin, 1996; Gregory et al., 1999), land use change (IPCC, 2001) and groundwater (Sandstrom, 1995; Allen and Scibek, 2006). 


\section{Conceptual Framework}

Climate adaptation is a behavioral change designed to influence natural or human systems in response to ongoing or expected climatic stimuli. The goal of adaptation is to reduce expected cost and to enhance opportunities to capture benefits. Optimal adaptation strategies vary in spatial and time dimensions. The interface of science and management is crucial to ensure the sharing of information and learning related to effective adaptive management of natural and built resources. The ability to capture information and gain knowledge during periods of rapid change is the essence of adaptive capacity, which accelerates the ability of a system to adjust to change and be resilient.

The adaptive capacities of the private and public sectors ${ }^{10}$ vary depending on their objectives, and the working methods they use to lessen the consequences of climate change. Nevertheless, the starting point is methodological individualism - analysis in which the individual is the basic unit of analysis. People or organizations/institutions use available resources and aptitudes to face adverse consequences that could lead to losses. The strengthening of coping capacities of individuals, communities or organizations usually builds resilience to withstand the effects of natural and human-induced hazards (UN/ISDR 2004).

10 Private sector adaptation (PSA): an effort/behavioral action implemented by households, individuals or private enterprises. Individual's rational self-interest is supposed to be a multivariate function ( $P A=f$ (attitude, education, profession, location, HHs income, information access etc.). Whereas, public adaptation (PA) is initiated and implemented by government at all levels to address collective needs. This is also multivariate and represented as: $P A=f$ (GDP, National Policy, International coop., community vulnerability, expected social return, market etc.) 
A plethora of research literature covers adaptation practices in a variety of sectors (Howden et al. 2007; Smit and Skinner, 2002). Structural responses (such as strategies to minimize the impact of flood and salinity intrusion) were found effective means to lessen impacts of climate change in a river basin (Birkmann 2011; Mai et al. 2009). Turral et al. (2010) identified structural measures feasible to deal with water scarcity as a result of drought, including flood forecasting (Plate, 2007), drought-tolerant varieties ( Birkmann et al. 2010; Chhetri and Easterling, 2010), and seasonal water harvesting (Smithers and Blay-Palmer, 2001) are other approaches found to support farm level resiliency.

Adaptation options vary along space and time dimensions. Adaptations at the local level have proven to be effective. Crop diversification (Bradshaw et al. 2004), and on-farm water management (Anuchiracheeva and Pinkaew, 2009) are examples of effective local water management practices. Chinvanno et al. (2008) emphasize the importance of local institutions in coping strategies of farmers. A climate change and adaptation study conducted in the Mekong river basin finds several effective adaptation practices at the local level to deal with the perceived risks of drought, floods, and salinity intrusion (Bastakoti et al., 2014). These practices involve autonomous adaptation focusing on coping with short-term risks rather than on long term climate risks. Adaptation measures include improving technical capacity of farming communities, subsidized farm inputs, improved access to credit and marketing management. It is important to understand the linkage between local and regional level adaptation strategies in order to ensure positive responses by markets to adaptation actions. 
A household can engage in a large variety of adaptation actions. The basic assumption regarding firm/farm behavior is that they will try to maximize their profits. Farm revenue and costs are functions of $n$ actions, $\mathrm{R}\left(\mathrm{a}_{1}, \ldots \ldots, \mathrm{a}_{\mathrm{n}}\right)$ and, $\mathrm{C}\left(\mathrm{a}_{1}, \ldots, \mathrm{a}_{\mathrm{n}}\right)$ respectively. Thus, it is assumed that firms and households choose actions $\left(\mathrm{a}_{1, \ldots} \ldots, \mathrm{a}_{\mathrm{n}}\right)$ so as to maximize

$$
\begin{gathered}
\mathrm{R}\left(\mathrm{a}_{1}, \ldots \ldots, \mathrm{a}_{\mathrm{n}}\right)-\mathrm{C}\left(\mathrm{a}_{1}, \ldots \ldots, \mathrm{a}_{\mathrm{n}}\right) . \\
\operatorname{Max}_{a_{1} \ldots \ldots \ldots a_{n}} R\left(a_{1} \ldots \ldots \ldots \ldots a_{n}\right)-C\left(a_{1} \ldots \ldots a_{n}\right) \\
\frac{\partial R(a)}{\partial a_{i}}=\frac{\partial C(a)}{\partial a_{i}} \quad i=1 \ldots \ldots n
\end{gathered}
$$

The firm's profit function will be as follows:

$$
\begin{aligned}
& \Pi(R, C)=\operatorname{Max} R f(X)-C X \quad \text { a short run profit function } \\
& \text { or, } \\
& \quad \Pi(P, W)=\operatorname{Max} P f(X)-W X
\end{aligned}
$$

Where $\mathrm{P}$, output price; $\mathrm{W}$, input price and $\mathrm{X}$ is the vector of inputs. Then F.O.C. for the single output profit maximization problem is

$$
P \frac{\partial f\left(X^{*}\right)}{\partial X_{i}}=W_{i} \quad i=1 \ldots \ldots \ldots \ldots n
$$

This condition states that the value of marginal product (VMP) of each input must be equal to its price during adaptation actions. The profit functions are monotonic, 
homogenous of degree one and convex in output price. The profit maximizing condition is shown in figure 1.

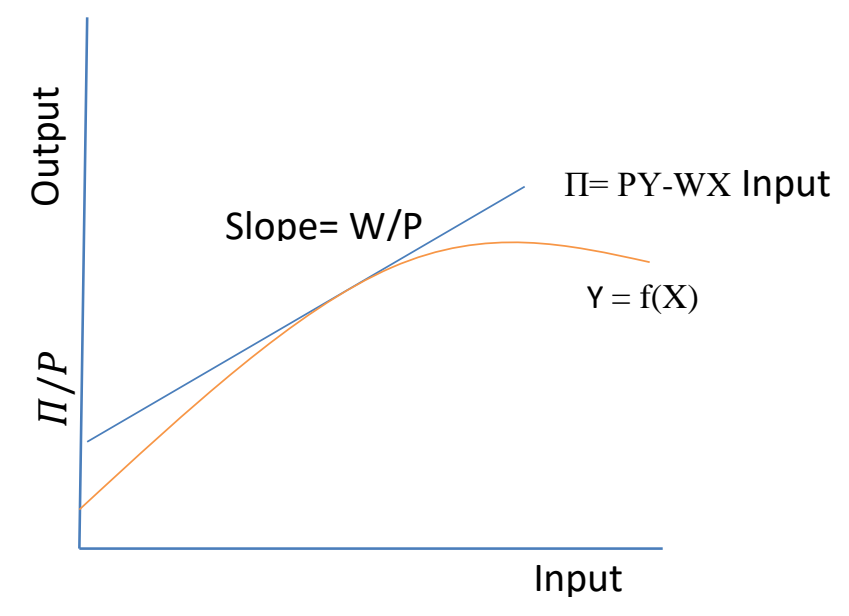

Fig. 1 Profit Maximization

The second order condition for profit maximization, namely that the second derivative of the production function with respect to the input is nonpositive (less than or equal to zero) is: $\frac{d^{2} f\left(x^{*}\right)}{d x^{2}} \leq 0$

This condition implies that at a point of maximal profit the production function must lie below its tangent line and appears as "locally concave". When the benefits derived from an adaptation strategy outweigh the incurred costs, this adaptation increases social welfare and augments societal resiliency in the long-run. 


\section{Analyzing Farmers' Adaptation Approach}

We assume that given changing climate, farmers will have an incentive to alter the use of their resources, in particular, to alter land use by choosing which crops to be grown and the timing and frequency of irrigation of these crops. Adaptation behavior is affected by the nature of the decision maker and various other exogenous variables. The behavioral options can be dichotomous or polychotomous. For our case, we will view the choice as a binary response (innovative adaptation or no change) and run logistic regression models to identify the most important variables influencing the choices made.

Individual agents (farmer and household heads) must choose between taking an adaptive action and not taking that action. For example, they may be faced with the decision whether or not to install a water-harvest tank during rainy season to use during the off-season (winter). In the binary $\left[A_{i} \in\{0,1\}\right]$ choice case, the objective is to estimate probability that the decision maker will choose change or not.

The probability of choosing change can be modelled using a logit model (Feder et al. 1985; Isham 2002; Foltz 2003). The logit ${ }^{11}$ model diagnoses the factors that condition the adaptation action (decision) under a changing environment in different ecological strata of Nepal.

11 In essence, both logit and probit model take the linear model and feed it through a function to yield a nonlinear relationship $\left(\widehat{A}=f\left(\beta_{0}+\beta_{n} Z_{n}\right)\right.$. Probit assumes cumulative distribution function of the standard normal distribution while logit assumes cumulative distribution function of the logistic distribution to define $f($.$) (Agresti, 2007).$ 
Let $\mathrm{A}^{*}$ be the unobserved adaptation decision, and $\mathrm{A}$ be the observed choice of an agent. Then the logit model can be defined as,

$A^{*}=Z^{\prime} \beta+u$

$A=\left\{\begin{array}{l}1, \text { if } A^{*}>0 \\ 0, \text { otherwise }\end{array}\right.$

Where $Z$ is a vector of exogenous variables; $\beta$ is the vector of parameters; and $u \sim N\left(0, \sigma^{2}\right)$.

Logit models assume that the agent's decision is a function of latent variables, and the adaptation decision is observed only when the latent variable exceeds the threshold value. The latent variable is hypothesized to be a function of household and farm (water resource and agricultural) characteristics. The coefficients observed in the model (Equation 3) are not marginal effects ${ }^{12}$ for continuous variables. The marginal effects in this model are derived as;

${ }^{12}$ The slope coefficient measures the change in the average value of the regressand for a unit change in the value of the regressor in linear regression models, ceteris paribus. In the logit model, the slope coefficient gives the change in the log of the odds associated with a unit change in that variable. In probit, the rate of change in the probability is somewhat complicated and given by $\beta_{j} f\left(R_{i}\right)$, where $f\left(R_{i}\right)$ is the density function of the standard normal variable and $R_{i}=\beta_{1}+\beta_{2} Z_{2 i}+\beta_{3} Z_{3 i}+\cdots \ldots \ldots \ldots+\beta_{n} Z_{n i}$, is the model used in this analysis. Thus probit and logit models look like similar (though not identical) in the sense that all the regressors are involved in computing the changes in probability (Gujarati, 2004. PP: 625). Hence, the interpretation of the coefficient is different. 


$$
\frac{\partial \hat{P}\left(A=\frac{1}{Z}\right)}{\partial Z_{i}}=\phi\left(Z^{\prime} \beta\right) \beta_{i}
$$

Where $\phi\left(Z^{\prime} \beta\right)$ is the standard normal density function. The partial marginal effect for any dummy variable $Z_{n}$ changing from 0 to 1 , ceteris paribus, is defined as;

$$
\Phi\left(\sum_{j \neq n} Z_{j} \beta_{j}+\beta_{n}\right)-\Phi\left(\sum_{j \neq n} Z_{j} \beta_{j}\right)
$$

Where $\Phi\left(Z^{\prime} \beta\right)$ is the standard normal cumulative distribution function of the logistic distribution (Green, 2011; Gujarati, 2004).

In the logit model, the independent variables are gender of the household head (farm manager), age of the household head, literacy of the household head, farm size, farm income, market access, extension service, credit access, market distance and migration. We expect that males are more willing to adopt the changes in farming practices. An educated farm manager with more years of farming experience would prefer adaptation strategies because of his skills in organizing farm inputs/outputs and learning capacity. Larger households may have more members to work in the farm and would not have shortage of farm labor. If a famer is contemplating migration, he would not invest in agricultural capital development (land improvement, machinery purchase, irrigation canal construction etc.) and would pay less attention to the adaptation strategies. Farms who have better access to a market center will procure agricultural inputs and able to sell their products on time. We would expect them to have more incentive and better information needed to adapt. The distance between the farm and 
market center is another factor in determining farm revenue. Long distances mean high transportation costs and the possibility of higher marketing loss (fresh products damage). This will reduce the farmer's incentive to invest in adaptations. We expect that access to extension services will provide farmers with the information and technical assistance they need to make adaptations. Those farmers with more access to credit have a smaller financial barrier to investing in adaptation technologies.

\section{Results and Discussions}

\subsection{Descrpitve Statistics}

The survey data indicated that about $20 \%$ of respondents are illiterate in the study regions. The highest rates of illiteracy $(24.6 \%)$ were in the Hill region which was followed by the Terai region $(21.33 \%)$ and the Mountain region (12.6\%). About $50 \%$ of respondents in all regions have at least some education above high school. The level of economically active population (age group: $16 \geq 59$ year) are about $72 \%, 70 \%$ and $72 \%$ in the Mountain, Hill and Terai regions respectively. This is an indicator that the residents of this region may be successful at adopting adaptation strategies.

The three dominant soil types are sandy loam, silt and sand. Fourteen percent of respondents in the Terai region have completely sandy land which was created by a devastating flood a decade ago. Likewise, $15 \%$ of households have clay loam soil in the Mountain region. The average percentage of sandy-loam, silt and sand holders in the Mountain region are $95 \%$, less than $1 \%$ and $5 \%$, in the Hill region $98 \%, 1.5 \%$ and $1 \%$ 
and in the Terai region $77 \%, 1 \%$ and $22 \%$ respectively. Focus group discussions (FGD) with senior citizens reveal that the desertification process is increasing. Repeated flooding has been a significant cause for land degradation (sand deposition).

Table 3. Descriptive statistics of survey parameters for the study regions

\begin{tabular}{llll}
\hline Average of variables & Mountain $(\mathrm{n}=150)$ & Hill $(\mathrm{n}=150)$ & Terai $(\mathrm{n}=150)$ \\
\hline Household size & $5.06(0.78)$ & $5.05(0.95)$ & $5.06(0.78)$ \\
Farm size & $15.69(6.88)$ & $12.6(5.31)$ & $25.34(15.9)$ \\
Distant from river basin & & & \\
$\quad$ River & $3.06(1.9)$ & $2.81(2.11)$ & $4.82(3.96)$ \\
$\quad$ Creek & $0.82(0.48)$ & $0.52(0.33)$ & $0.93(0.8)$ \\
Water used & & & $121.54(115.3)$ \\
$\quad$ Crops & $61.2(73.4)$ & $51.63(68.54)$ & $90.62(35)$ \\
$\quad$ Livestock & $58.3(19.48)$ & $53.45(26.63)$ & $87.23(26.49)$ \\
$\quad$ Household & $53.85(13.2)$ & $66.46(36.36)$ & $0.1(0.09)$ \\
Water cost & & & $0.11(0.1)$ \\
$\quad$ Crop/Livestock & $0.10(0.29)$ & $0.21(0.12)$ & $1.13(0.85)$ \\
$\quad$ Household & $0.21(0.30)$ & $0.26(0.15)$ & $0.019(0.018)$ \\
Distant to water sources & & & $5.96(1.83)$ \\
$\quad$ Agricultural water & $1.6(1.26)$ & $0.51(0.28)$ & $0.19(0.15)$ \\
$\quad$ Household water & $0.69(0.35)$ & $5.41(4.45)$ & \\
Livestock herd size & $6.97(2.46)$ & & \\
\hline
\end{tabular}

Source: Field survey, 2015. Values in the parentheses indicate standard deviation (SD)

Fragmented and terraced land in the Mountain and Hill regions are constraints on adopting mechanized farming. Investment to develop climate change resiliency in agriculture to boost agrarian livelihood has been very limited to date in the regions. This has led to low productivity and reduced household food availability. Only $52 \%$ of the respondents in the study area have year round food security whereas $10 \%$ have less than 
three months of food security from the on-farm activities. More than $75 \%$ of respondents in all regions reported declining numbers of the local breed of livestock. The average farm size is 15.69, 12.6 and 25.34 ropani in Mountain, Hill and Terai regions respectively. Average livestock holdings are 6.9, 5.4 and 5.9 animals in the Mountain, Hill and Terai regions respectively (Table 3). Discussion with residents of the region reveals that in a decade livestock holding has decreased by about $60 \%$. The reasons are degrading pasture, forest degradation, water source collapse and tropical forest clearance.

The survey results indicate differences in cropping intensity between farmers who are involved in adaptation practices designed to manage agricultural water and agronomic practices in all regions, and those who have not adapted (Table 4). Current period benefitcost ratio calculated between non-adaptive and adaptive agricultural farms is presented in Table 5. Benefit cost ratios of adaptive farms in Mountain and Hill are about twice the ratio calculated for non-adaptive farms. Focus group discussion revealed that farmers started adaptation measures very recently (past 3-4 years).

Table 4. Cropping intensity between the adaptive and non-adaptive farming systems

\begin{tabular}{llll}
\hline Situations & Mountain & Hill & Terai \\
\hline Adaptation to water resources & 1.62 & 1.98 & 2.75 \\
Nonadaptation to water resources & 1.24 & 1.6 & 1.72 \\
\hline
\end{tabular}

Source: Field Survey 2015 and FGD, 2015

Both agricultural and household water management have been increasingly time consuming activities. The increasing time required to manage water in the Mountain and Hill regions is due to sharp reduction in water availability in winter and summer seasons 
in the creeks, and declining output of natural springs which are the primary sources of water for agricultural and household uses respectively. One response has been the formation of community water user groups (CWUG). CWUG are a mechanism for cost sharing projects designed to protect water sources (especially natural springs) and to prevent seepage and spills, and to distribute water via plastic pipe to individual households or to central points, accessible to all CWUG members.

Table 5. Economic indicators (mean value) between non-adaptive and adaptive farming

\begin{tabular}{|c|c|c|c|c|c|c|}
\hline \multirow[t]{2}{*}{ Indicators } & \multicolumn{2}{|l|}{ Mountain } & \multicolumn{2}{|l|}{ Hill } & \multicolumn{2}{|l|}{ Terai } \\
\hline & $\begin{array}{l}\text { Non- } \\
\text { adaptive }\end{array}$ & Adaptive & $\begin{array}{l}\text { Non- } \\
\text { adaptive }\end{array}$ & Adaptive & $\begin{array}{l}\text { Non- } \\
\text { adaptive }\end{array}$ & Adaptive \\
\hline Gross Margin & 4.66 & 71.72 & 3.16 & 34.3 & 39.51 & 60.61 \\
\hline (Rs. '000) & $(3.76)$ & (56.93) & $(2.8)$ & (14.82) & (40.03) & $(44.87)$ \\
\hline $\begin{array}{l}\mathrm{B} / \mathrm{C} \text { ratio }^{13} \\
\text { (Income to }\end{array}$ & $1.13(1.42)$ & $2.73(1.46)$ & $1.11(0.9)$ & $2.11(2)$ & $1.78(1.83)$ & $2.02(1.9)$ \\
\hline cost ratio) & & & & & & \\
\hline
\end{tabular}

Source: Field survey 2015. Values in the parentheses indicate standard deviation (SD)

In the Mountain region, $100 \%$ of respondents are experiencing increasing time to manage water for both agricultural and household use. The time requirement has increased by $10.89 \%, 12.77 \%$ and $11.42 \%$ over the last 10 to 15 years in the Mountain, Hill and Terai regions respectively.

\footnotetext{
${ }^{13}$ This is not a discounted benefit cost ratio. Dealing with annual crops, there is no need to discount as the discounting factor will be one. Therefore, in such cases, $B C R=$ gross income $/$ cost. Gross income $=($ quantity of main products * price of the products) + (quantity of byproducts* price of byproducts) and Cost $=$ expenses incurred for agronomic operations in terms of labor and farm machinery operation, and farm inputs (seed, fertilizers, irrigation, plant protection measures and farm yard manure ) cost.
} 
On average, respondents in the Mountain, Hill and Terai regions are willing to pay $78.24 \%, 62.24 \%$ and $76.33 \%$ more than the base price of water. It is important to note that people are willing to pay a much higher percentage more for clean drinking water as compared to agricultural water. Residents of the Mountain region suffer because of remoteness and scattered water sources such as natural springs and small rivulets. Residents of the Hill region are constrained by lower water levels in creeks and natural springs, disappearing springs due to deforestation and the infeasibility of lifting the water from rivers into the high hills. The Terai region is severely impacted by upstream forest degradation, landslides and unusual rainy-season flooding. This makes surface water unsafe to use under existing conditions. A majority of the poor, socio-culturally oppressed ethnic community and marginal farm families reside in the river basin or immediately adjacent to the catchment areas. They are unable to invest for water treatment and other facilities to renovate water sources.

Only $14 \%$ of respondents from the Terai region have installed irrigation pumps to water cereal crops and vegetables (mostly beans). No one has irrigation pumps in the Mountain and Hill regions. To date, there is no ground water provision in the Mountain and Hill regions whereas $100 \%$ of respondents in the Terai region use ground water for livestock and in-house activities. Irrigation water in the Terai region includes both surface and ground water. In the study region, about a third (34\%) of respondents uses ground water for crop production. Ground water consumption in the Terai region is increasing due to migration from the Hill and Mountain regions, urbanization and 
increasing population density. Respondents' experience, as well as study data, reveal that livestock is a profitable venture in the Terai region because of better market access and a conducive environment for livestock rearing. Cattle (milching) are the dominant animal kept to support households. Due to the tropical climate, these animals require more water than those in the Hill and Mountain regions. Meeting in-house and livestock water requirements is critical to the small holder's livelihood. Water allocation between crop production and livestock is based on the expected net returns from these competitive sectors. As market and water resource availability change, farmers change their use of water for production of off-season vegetable and some specific crops (kidney beans at present). These types of decisions are examples of place specific local-knowledge-based adaptation practices, which, when effective can lead to greater water resource resiliency.

Ground water users are very diverse. Households, who have pumps and access to deep drilling equipment, are able to withdraw much more ground water than those having only natural wells, cemented wells and shallow tube wells. On the basis of the key informant survey and data from the field survey we conclude that ground water extraction is increasing in aggregate, but decreasing for small holders, ultra-marginal households, the landless and memebers of lower caste (untouchables). 
Table 6. Frequency distribution of respondent's perception of future water availability

\begin{tabular}{lllll}
\hline $\begin{array}{l}\text { Perception on meeting future } \\
\text { demand }\end{array}$ & Mountain & Hill & Terai & Total \\
\hline Hard to meet & $28(18.67)$ & $55(36.67)$ & $50(33.33)$ & $133(29.56)$ \\
Possible to meet & $122(81.33)$ & $85(56.67)$ & $100(66.67)$ & $307(68.22)$ \\
Impossible to meet & $0(0)$ & $10(6.67)$ & $0(0)$ & $10(2.22)$
\end{tabular}

Source: Field Survey 2015. Values in the parentheses indicate standard deviation (SD)

Our survey indicates that no one in the Mountain and Terai regions, and only $6.67 \%$ of those in the Hill region believed it would be impossible to meet future water demand. However, it is notable that more than $50 \%$ of respondents in the Hill and Terai regions believe that it will be hard to meet the demand for agriculture and household water (Table 6). From the focus groups and the key informant surveys in each region, the following opinion has been collected (Box 1). 


\section{Box 1: Opinions of the respondents}

People in the mountain region don't think water scarcity will be a serious issue in the near future even if recent climate change trends continue. Government investment in new dams and mechanisms to assure an equitable distribution of water is required. Farmers in all regions fear the consequences of awarding private licenses for hydropower development. They believe this would reduce the surface water availability to agriculture. Collective action to conserve natural springs would only sustain life for another 2-3 decades. Steady outmigration from the upper hill and mountain regions will eventually reduce water demand in these regions. However, the lower Hill and Terai regions will not be able to sustain higher water demand. Most farmers prefer cash crops such as medicinal and aromatic plants and temperate fruits (apple, plum, etc.) to cereal crops. These products would demand significantly less water but offer lucrative income. They conclude that access to markets and an effective market information system are important means to respond to climate change impacts on water resource by leading to appropriate farming system change. In the Hill region, discussants in the focus groups emphasized behavioral change such as adopting collective management of water resources, more efficient in-house water use, rain water harvesting, drip irrigation, water source protection, etc. Afforestation, reforestation, cover cropping and avoiding pollution of the riverine system are urgently needed actions to develop greater resiliency of water resource dependent livelihoods. There is clear competition for water amongst households, agriculture and the hydropower sector. It is believed that licensing individual firms and private to generate hydropower and produce retail bottled water sometimes jeopardizes the water rights of up-stream and downstream communities. This would create conflict in the political and economic scale. Residents of the Terai region believe the situation is serious. If government enforces strong rules regarding natural resource conservation, especially forest and riverine systems, the situation could improve. Recent increases in industrial waste disposal in rivers and streams are a major problem. Aquatic biodiversity is decreasing very sharply. The frequency of flooding is increasing. Deforestation and increased flooding (intense raining after prolonged drought) is accelerating desertification in southern region of the Terai region. Siltation has been a problem in the flat land near the river banks. Despite these issues, respondents believe that agricultural water management in the Terai region is possible and economically feasible. Irrigation canal construction is feasible and best solution to combat water stress in the Terai region. This strategy could at least double the current level of crop yields, ceteris paribus. In the near future, government must install surface water treatment plants to supply drinking water. Ground water levels are falling. In 10-15 years, elderly people have experienced at least 3 to 7 meter reductions in the water table. Poor and marginally poor people cannot invest for deep wells and must rely on rarely excavated wells or shallow tube-well. Many lower caste families are without clean drinking water for days at a time, and must drink unsafe surface water, resulting in diarrhea and tropical diseases (worms for example). This is a culturally ingrained bias and injustice. There is fairly high possibility of future violence in the community. Strategies proposed to ensure more sustainable water resources include: less reliance on ground water; forest protection to allow regular ground water recharge; reestablishment of tropical forests along the riverbank; prohibiting dumping of industrial waste and garbage in the river; mulching to keeps top soil wet for longer periods; increasing minimum or zero tillage to reduce evaporation, and maximize proportion of rainfall and minimize water loss such as runoff, drainage, seepage, evaporation and weed control.

Source: 13 participants, age range: 31-79. FGD, 2015 
Respondents were asked to choose from a list of policies that they believed would create sustainable water availability and greater water resiliency (recorded in "Check all that apply" format). We found that $100 \%$ of respondents in the Mountain region preferred collective water management while no respondents preferred private action (Table 7). The ethnic and lower caste section of the population expects public provision of water resource management. However, based on in-depth discussion with members of the community, they would prefer to manage resource allocation in the small groups within their own community (same caste). This suggests that there is tenuous societal cohesion and a weak degree of confidence in large groups.

Table 7. Feasible approaches to water resource management in the study regions

\begin{tabular}{lllll}
\hline Approaches & Mountain & Hill & Terai & Total \\
\hline Collective & $150(100)$ & $108(72)$ & $128(85.33)$ & $386(85.78)$ \\
Private & $0(0)$ & $30(20)$ & $43(28.67)$ & $73(16.22)$ \\
Public & $78(52)$ & $87(58)$ & $63(42)$ & $228(50.67)$ \\
PPP & $65(43.33)$ & $68(45.33)$ & $95(63.33)$ & $228(50.67)$
\end{tabular}

Source: Field Survey 2015. Values in the parentheses indicate percentage

About $24 \%$ of respondents in the Mountain region experienced increased water availability over the period of 10-15 years especially during late winter through summer. This has been mainly due to increased temperature and glacier retreat. Another reason for increased water availability in the Mountain region are ongoing cropping pattern change (from cereals to non-timber forest products) and decreasing population density due to migration. Farmers cannot reckon exact temperature trend but intuitively observe and make reference to temperature fluctuations. Farmers collect climate change evidence by observing deciduous plant blossoms, crop maturation, animal estrus-cycle and bird 
migration. In addition, phenomena such as lower humidity, ants in creeks and natural springs, drying up of natural springs and reduced numbers of earthworm are direct experiences of farmers that indicate to them that climate change is having an impact on their livelihood. This emphasizes the importance of local and indigenous knowledge as inputs in designing place-based adaptation plans.

Irrigation water primarily comes from the natural seasonal precipitation (green water ${ }^{14}$ ) and blue water ${ }^{15}$. However, the quality of irrigation water is a function of embodied water quality itself, the quality of water delivery route (canal) and other unseen external factors. No one in the Hill region reported that irrigation water quality had improved over the last 10 to 15 years. The response to this question of increasing water quality was very low (6\%) in the Mountain region and $14 \%$ in the Terai region.

\subsection{Climate Change and Observed Changes in Precipitation, Wind and Temperature}

All ecological regions in the study area have been experiencing climate change impacts on water resources, forests and farming systems. Of the total, $91.33 \%, 89.33 \%$ and $86 \%$ of respondents in the Terai, Mountain and Hill regions, respectively have heard of, and personally felt negative impacts of climate change in their surroundings and livelihoods. In total, $88.22 \%$ of respondents noticed less rain over the previous 10 to 15

\footnotetext{
${ }^{14}$ The precipitation on land that does not run off or recharge the groundwater but is stored in the soil or temporarily stays on top of the soil or vegetation. Source: http://waterfootprint.org/en/waterfootprint/glossary/\#BW

${ }^{15}$ Fresh surface and groundwater, in other words, the water in freshwater lakes, rivers and aquifers. Source: http://waterfootprint.org/en/water-footprint/glossary/\#BW
} 
years (Table 8). Respondents reported they are experiencing increasingly erratic and intense rainfall as compared to a decade back. Temperatures in the regions are increasing. All respondents in the Terai region reported increased temperatures. People also reported stronger winds in the Hill and Mountain regions. The combined effects of higher winds, erratic rainfall and higher temperature are serious threats to people's traditional livelihoods.

Table 8. Frequency distribution of reported changes in rainfall patterns

\begin{tabular}{lllll}
\hline Change in rainfall & Mountain & Hill & Terai & Total \\
\hline Less & $143(95.33)$ & $128(85.33)$ & $126(84)$ & $397(88.22)$ \\
More & $0(0)$ & $0(0)$ & $0(0)$ & $0(0)$ \\
Erratic & $5(3.3)$ & $16(10.67)$ & $13(8.67)$ & $34(7.56)$ \\
Intense & $2(1.33)$ & $6(4)$ & $11(7.33)$ & $19(4.22)$ \\
\hline
\end{tabular}

Source: Field Survey 2015. Values in the parentheses indicate percentage

However, in a question about potential benefits of increased temperature if any, $15.33 \%$ of respondents in the Mountain region, most of whom reside in the northern face in of the Mountain terraces, reported that since they are exposed to just a few hours of sunshine each day, are benefited by increasing temperatures. Farmers reported the following advantages and disadvantages of increased temperature in their region (Table 9). In some places more rainfall is occurring during post-monsoon and rainy periods which lead to flash floods in the Hill region and severe flooding in the Terai region. In aggregate, rainfall is decreasing. 
Table 9. Advantages and disadvantages of increased temperatures

\begin{tabular}{|l|l|}
\hline Advantages & Disadvantages \\
\hline$\bullet \quad$ Crop production increased by & $\bullet \quad$ More insect-pests prevalence, \\
$20-25 \%$ & mosquitos in summer. \\
$\bullet \quad$ Reduced need to melt ice using & $-\quad$ Foot and Mouth disease \\
firewood in summer. That saved about & (FMD) outbreak in goat and sheep \\
Rs. 2000/year & - Some medicinal and aromatic \\
Vegetable production and & plants (MAP) such as Yarsagumba \\
consumption increased worth Rs.4200 & (Ophiocordyceps sinensis) are now \\
per year compared to 5 to 7 years ago. & extinct. \\
& $\bullet \quad$ Gradual reduction in floral \\
& diversity. \\
& Rhododendron and hence degraded \\
& flavor of its sorbet++.
\end{tabular}

Source: FGD, 2015

++ Rhododendron sorbet has been produced and marketed for more than a decade in local settings without any modern technical knowledge. It is a local resource based small-scale microenterprise activity in the Mountainous areas of far western and the central region of Nepal.

\subsection{Water Level Change in Creeks/Rivulets}

All respondents in the Hill and Terai regions, and $90 \%$ of respondents in the Mountain region reported that water had decreased in creeks. Reported water level reductions in creeks/rivulets in the three regions are presented in Table 10. The other two choices — no water loss, and increase in the creeks over the period of time-were found void. 
Table 10. Respondent's observation regarding water loss in creeks over the previous 5 to 7 years

\begin{tabular}{lllll}
\hline$\%$ loss of water & Mountain & Hill & Terai & Total \\
\hline $50 \%$ & $89(59.33)$ & $4(2.67)$ & $11(7.33)$ & $104(23.11)$ \\
$75 \%$ & $54(36)$ & $113(75.33)$ & $109(72.67)$ & $276(61.33)$ \\
$100 \%$ & $7(4.66)$ & $33(22)$ & $30(20)$ & $70(15.55)$ \\
\hline
\end{tabular}

Source: Field Survey 2015. Values in the parentheses indicate percentage

\subsection{Economic Impacts of Landslides and Floods}

About $65 \%$ of respondents have experienced flooding in the study area. The highest incidence of flooding (86.67\%) was experienced by residents of the Terai region followed by $77 \%$ and $36 \%$ in the Hill and Mountain regions respectively. Landslides in the Mountain and Hill regions and floods in the Hill and Terai regions cause permanent loss of terraced land, siltation of reservoirs and water stagnation. Temporary loss of use of land (because of flooding and/or less severe damage to terraces) could be restored but seems costly in some cases. Respondents reported, permanent and temporary land loss due to extreme climate events (flood, flash flood, intense rain, dry-landslide and wetlandslide) is increasing remarkably in the regions. The focus groups revealed that the number of events and magnitude of arable land loss has increased by $7.5 \%$ and $5 \%$ annually, respectively. This may leads to significant economic loss in the region and is especially costly to the small holders who lack resources to recover and upgrade their land. Permanent land loss in the Terai region is due to flooding during the rainy season from the Koshi River and its auxiliary rivulets while landslides are the main cause of land loss in the Mountain and Hill areas. Permanent land loss in the Mountain, Hill and Terai regions were reported to be $23.33 \%, 9.33 \%$ and $42.0 \%$ respectively. 
No one in the Mountain region reported any losses due to excessive precipitation but $12.0 \%$ of respondents in the Terai region and $23.33 \%$ of respondents in the Hill region reported on-farm economic losses due to intense precipitation over the previous 10 to 15 years. High temperature and drought are seemingly interrelated in the Terai region and to some extent in the Hill region. However, residents of the Mountain region reported extremely cool weather coupled with drought. Respondents reported both dry and wet landslides. Monetary estimations of economic losses due to droughts, excess precipitation, floods and landslides are presented in table 11.

Table 11. Average on-farm economic losses from the consequences of climate change (NRs. ' 000 /family) during the previous 5 to 7 years

\begin{tabular}{llllll}
\hline \multirow{2}{*}{ Climate change effect } & \multicolumn{5}{l}{ Average economic loss (NRs/Year) } \\
\cline { 2 - 6 } & Mountain & Hill & Terai & Total & Rank \\
\hline Over precipitation & $0(0)$ & $0.25(0.65)$ & $0.23(0.86)$ & $0.16(0.63)$ & 4 \\
Drought & $4.78(5.09)$ & $4.95(2.3)$ & $8.03(6.7)$ & $5.93(6.13)$ & 1 \\
High temperature & $0.41(1.02)$ & $0.6(0.82)$ & $1.04(0.97)$ & $0.69(0.97)$ & 3 \\
Flood++ & $1.13(2.29)$ & $0.45(0.97)$ & $4.14(8.23)$ & $1.91(5.2)$ & 2 \\
Landslide & $0.1(0.27)$ & $0.32(0.63)$ & $0(0)$ & $0.14(0.41)$ & 5 \\
Total & $6.44(4.51)$ & $6.56(2.92)$ & $13.45(7.51)$ & $8.82(6.25)$ & \\
\multicolumn{7}{l}{ Source: Field Survey 2015. Values in the parentheses indicate standard deviation (SD) } \\
++ In the high hills and mountains, flooding is mostly in the form of flash floods
\end{tabular}

\subsection{Climate Change Adaptation and Land Use Pattern Change}

One third of respondents in the Mountain region and about $50 \%$ in the Hill and Terai regions are either adapting to climate change impacts or are experiencing some degree of benefits from climate change. Table 12 records the number and proportion of 
respondents who have adopted any of the adaptation measures to develop farming system resiliency related to water resources. Until recently, drought resistant varieties were either unavailable publicly or were unsuitable in the given physiographic characteristics of the region.

Table 12. Adaptation measures in study regions

\begin{tabular}{llllll}
\hline Adaptation measures & Mountain & Hill & Terai & Total & Rank \\
\hline Planting time adjustment & $20(13.33)$ & $33(22)$ & $51(34)$ & $104(23.11)$ & 3 \\
Varietal selection & $50(33.33)$ & $39(26)$ & $71(47.33)$ & $160(35.55)$ & 1 \\
Less water technology & $25(16.66)$ & $38(25.33)$ & $61(40.66)$ & $124(27.55)$ & 2 \\
Drought resistant variety & $0(0)$ & $2(1.33)$ & $0(0)$ & $2(0.44)$ & 4 \\
\hline
\end{tabular}

Source: Filed Survey 2015. Values in the parentheses indicate percentage

In the study areas, $62.22 \%$ of respondents have not adopted any measures to adapt to climate change. Reasons for not adopting any measures are presented in Table 20. About $69 \%$ of respondents reported that if they had had the government extension services in the community, they would have known about required farm inputs and their costs, and had an output market perspective. This would help farmers decide to adopt resiliency measures. Respondents reported lack of extension services, high input costs, and lack of reliable farm inputs as the three major reasons for not adopting resiliency measures (Table 13). Education, household economy, remoteness and lack of government extension services are factors explaining the respondents' level of self-confidence. Farmers have multiple reasons why they have not adopted new technology to respond to changing climate. 
Table 13. Reasons for not adopting resiliency measures

\begin{tabular}{llllll}
\hline Reasons & Mountain & Hill & Terai & Total & Ranks \\
\hline High cost & $50(33.33)$ & $83(55.33)$ & $51(34)$ & $184(40.88)$ & 2 \\
Uncertain output market & $15(10)$ & $25(16.66)$ & $9(6)$ & $49(10.88)$ & 5 \\
Lack of inputs & $100(66.66)$ & $42(28)$ & $39(26)$ & $181(40.22)$ & 3 \\
Lack of extension services & $100(66.66)$ & $129(86)$ & $79(52.66)$ & $308(68.44)$ & 1 \\
Lack of self confidence & $0(0)$ & $34(22.66)$ & $24(16)$ & $58(12.88)$ & 4 \\
\hline
\end{tabular}

Source: Field Survey 2015. Values in the parentheses indicate percentage

Table 14. Reasons of land use pattern change

\begin{tabular}{llllll}
\hline Reasons & Mountain & Hill & Terai & Total & Ranks \\
\hline Prevalence of & $19(12.67)$ & $23(15.33)$ & $5(3.33)$ & $47(10.44)$ & V \\
pest/disease & & & & & \\
Reduced water level & $60(40)$ & $64(42.67)$ & $110(73.33)$ & $234(52)$ & I \\
Increased water level & $27(18)$ & $0(0)$ & $40(26.66)$ & $67(14.89)$ & IV \\
Decreased productivity & $45(30)$ & $61(40.67)$ & $54(36)$ & $160(35.56)$ & II \\
New profit venture** & $70(46.67)$ & $38(25.33)$ & $10(6.66)$ & $118(26.22)$ & III \\
\hline
\end{tabular}

Source: Field Survey 2015. Values in the parentheses indicate percentage

** Domestication of medicinal and aromatic plants, off-season vegetable production, and other market led production

The survey results show the changes in land use and land cover in Koshi River Basin. These changes in land use and land cover have caused both positive and negative impacts on the livelihood of residents and on the region's environment. Environmental problems such as soil erosion, sand cover, and siltation of reservoirs, river bank erosion and inundation of lowland areas are visible. Over the previous 10 to 15 years, approximately $71 \%$ of respondents have changed their land use patterns. The underlying reasons behind land use/land cover change are presented in the Table 14. More than half of the respondents $(52 \%)$ changed their land use due to reduced water level. 


\subsection{Institutional Involvement and Preferred Adaptation Approach}

Current extension services provide assistance related only to farming practices such as land preparation, seed rate, fertilizer and crop protection. There are no extension programs related to climate change information, adaptation practices and water resource management. Similarly, the forest and soil conservation department of the Nepal government has no specific programs to address the climate, water and forest nexus. One recent program called crop diversification provides some government support for combating complete crop failure. Some respondents, $6.66 \%$ in the Mountain region, $19.33 \%$ in the Hill region and $13.33 \%$ in the Terai region, have received support under this program.

Access to credit and electricity enhance peoples' capacity for adaptation and mitigation actions in response to environmental changes in water resources. Farmers report that credit and electricity increases the efficiency of production through better post-harvest management of crops. For example, uninterrupted electricity allows the use of water pumps. However, one-third of the respondents do not have access to power. Similarly only around $60 \%$ of respondents have access to formal credit. Those without access to formal credit must rely on informal financial institutions such as landlords, and creditors who charge exorbitantly high interest rates (as high as $40 \%$ per annum). Credit constraint limits investments in agriculture especially among smallholders and members of marginalized ethnic communities. 
About 30\% of respondents prefer small group approaches to implementation of adaptation strategies in agricultural water management, followed by individual approaches (22.88\%) and community action (22.66\%) (Table 15). The preference for small group approaches is due to the heterogeneous caste system. Public approaches to the problem, were least favored by residents of the Mountain regions because of high transaction costs, and in Terai due to acute poverty in certain disadvantaged communities. All respondents indicated an interest in adopting feasible measures to improve their agrarian based livelihoods. Credit availability from formal financial institutions, improved market access (i.e. better market information services, road, public transportation, etc.) and subsidized farm-inputs were listed as the top three support measures to enhance adaptation actions in the study region (Table 16). A majority of poor respondents preferred farm-input subsidies rather than better market access. This group is not as concerned about output markets since they are more reliant on agriculture for subsistence and because of they are often food secure less than six months of the year.

Table 15. Preferred adaptation approaches (agricultural water)

\begin{tabular}{llllll}
\hline Approaches & Mountain & Hill & Terai & Total & Rank \\
\hline Individual & $29(19.33)$ & $34(22.66)$ & $40(26.66)$ & $103(22.88)$ & 2 \\
Small group & $34(22.66)$ & $44(29.33)$ & $55(36.66)$ & $133(29.55)$ & 1 \\
Community & $39(26)$ & $49(32.66)$ & $14(9.33)$ & $102(22.66)$ & 3 \\
Public & $39(26)$ & $11(7.33)$ & $34(22.66)$ & $84(18.66)$ & 4 \\
Public-Private partnership & $9(6)$ & $12(8)$ & $7(4.66)$ & $28(6.22)$ & 5 \\
\hline
\end{tabular}

Source: Field Survey 2015. Values in the parentheses indicate percentage 
Table 16. Preferred measures to support effective adaptation

\begin{tabular}{llllll}
\hline Supports & Mountain & Hill & Terai & & Rank \\
\hline Better market access & $40(26.66)$ & $44(29.33)$ & $13(8.66)$ & $97(21.55)$ & 2 \\
Extension services & $34(26.66)$ & $28(18.66)$ & $24(16)$ & $86(19.11)$ & 4 \\
Human skills/trainings & $18(12)$ & $14(9.33)$ & $32(21.33)$ & $64(14.22)$ & 5 \\
Input subsidies & $22(14.66)$ & $12(8)$ & $56(37.33)$ & $90(20)$ & 3 \\
Credit with low interest & $36(24)$ & $52(34.66)$ & $25(16.66)$ & $113(25.11)$ & 1
\end{tabular}

Source: Field Survey 2015. Values in the parentheses indicate percentage

\subsection{Factors Affecting Adaptation Decision to Water Resources in Agriculture}

The logistics regression results suggest that in the Mountain region, farm income, better market access, access to extension services, plans to migrate, and distance from the market are statistically significant predictors of adaption activity at the 5\% significance level. Specifically, individuals with higher incomes, and individuals living farther from the closest market are more likely to undertake adaptive actions in regards to water resource management in agriculture. (Table 17). The age of respondents, their literacy, family size, farm size, and access to credit had no significant effect on people's decision to undertake adaptive strategies. 
Table. 17 Binary logit analysis of decision to adopt adaptation measures in the Mountain region $(\mathrm{n}=150)$

\begin{tabular}{lllll}
\hline Variables & $\begin{array}{l}\text { Marginal effects }{ }^{16} \text { at the } \\
\text { mean }(\mathrm{MEM}): \partial \mathrm{y} / \partial \mathrm{x}\end{array}$ & & $\mathrm{P}>|\mathrm{z}|$ \\
\hline Gender & -0.0509 & 0.7455916 & 0.49109 & 0.656 \\
Age & 0.0016 & 1.009296 & 0.03684 & 0.800 \\
Literacy & -0.0528 & 0.7374561 & 0.68532 & 0.743 \\
Household size & -0.00934 & 0.9475988 & 0.32237 & 0.874 \\
Farm size & -0.00032 & 0.998123 & 0.04011 & 0.963 \\
Farm income & 0.000012 & 1.000069 & 0.00001 & 0.000 \\
Market access & -0.1979 & 0.319855 & 0.08408 & 0.000 \\
Extension service & -0.5090 & 0.0470197 & -3.32 & 0.009 \\
Contemplating & -0.3751 & 0.1152766 & 0.08960 & 0.005 \\
migration & & & & \\
Credit access & 0.0970 & 1.748242 & 0.88769 & 0.271 \\
Market distance & 0.1884 & 2.959776 & 0.76566 & 0.000 \\
Constant & & 0.0011308 & 0.00363 & 0.035 \\
Log likelihood = -55.848062 & & & \\
Pseudo R2 = 0.4151 & & & & \\
\hline Source: Fid survey & & & & \\
\hline
\end{tabular}

Source: Field survey, 2015. STATA 13.0 output

Results from the Hill region of Nepal show that male respondents were more than six times more likely to undertake adaptive measures than female respondents, and the result is statistically significant at the $95 \%$ confidence level (Table 18). Likewise, those with higher farm income, access to extension services, and those living closer to market places were found to be more concerned about adaptive water resource management, and

\footnotetext{
${ }^{16}$ Marginal Effect, $Z_{k}=\operatorname{Pr}\left(Y=1 \mid Z, Z_{k}=1\right)-\operatorname{Pr}\left(y=1 \mid Z, Z_{k}=0\right)$ is used for categorical variables. Put another way, for a continuous variable $X k$, Marginal Effect of $Z_{k}=\operatorname{limit}\left[\operatorname{Pr}\left(Y=1 \mid Z, Z_{k}+\Delta\right)-\right.$ $\left.\operatorname{Pr}\left(\mathrm{y}=1 \mid \mathrm{Z}, \mathrm{Z}_{\mathrm{k}}\right)\right] / \Delta$ ] as $\Delta$ gets closer and closer to 0 .
} 
all the results are statistically different than zero. Again age, literacy, willingness to migrate, family size, farm size and access to market had no significant effect.

Table. 18 Binary logit analysis of decision to adopt adaptation measures in the Hill region $(\mathrm{n}=150)$

\begin{tabular}{|c|c|c|c|c|}
\hline Variables & $\begin{array}{l}\text { Marginal effects at the } \\
\text { mean (MEM): } \partial \mathrm{y} / \partial \mathrm{x}\end{array}$ & Odds ratio & SE & $\mathrm{P}>|\mathrm{z}|$ \\
\hline Gender & 0.3627 & 6.268775 & 5.47051 & 0.035 \\
\hline Age & 0.0053 & 1.027606 & 0.04094 & 0.494 \\
\hline Literacy & 0.1331 & 1.962 & 1.69030 & 0.434 \\
\hline Household size & -0.0548 & 0.7576776 & 0.23116 & 0.363 \\
\hline Farm size & -0.0272 & 0.8709959 & 0.08011 & 0.133 \\
\hline Farm income & 0.00002 & 1.000112 & 0.00002 & 0.000 \\
\hline Market access & -0.00236 & 0.9881067 & 0.28780 & 0.967 \\
\hline Extension service & -0.3802 & 0.1459837 & 0.09377 & 0.003 \\
\hline Contemplating migration & 0.0381 & 1.212754 & 0.12387 & 0.059 \\
\hline Credit access & 0.0781 & 0.0067112 & 0.01560 & 0.031 \\
\hline Market distance & 0.0641 & 6.268775 & 5.47051 & 0.035 \\
\hline Constant & & 1.027606 & 0.04094 & 0.494 \\
\hline \multicolumn{5}{|c|}{ Log likelihood $=-47.542746$} \\
\hline \multicolumn{5}{|l|}{ Pseudo R2 $=0.4983$} \\
\hline
\end{tabular}

Source: Field survey, 2015. STATA 13.0 output

The results for the Terai region also give us some interesting results. Here, the farm size, extension services and distance to nearest market had statistically significant effects on the decision to adapt. Individuals with larger farms are less worried about adaptive measures, as are people with easier access to market, greater distance from the market, and for those with easy access to extension services. Variables with results that 
are statistically indistinguishable from zero include gender, age, income, willingness to migrate, access to credit, and farm size (Table 19).

Table. 19 Binary logit analysis of decision to adopt adaptation measures in the Terai region $(\mathrm{n}=150)$

\begin{tabular}{lllll}
\hline Variables & Marginal effects at the & Odds ratio & SE & $\mathrm{P}>|\mathrm{z}|$ \\
& mean $(\mathrm{MEM}): \partial \mathrm{y} / \partial \mathrm{x}$ & & & \\
Gender & 0.1880 & 3.755763 & 3.66366 & 0.175 \\
Age & 0.0022 & 1.016309 & 0.06096 & 0.787 \\
Literacy & 1.6189 & 88457.76 & 1464782 & 0.492 \\
Household size & 0.1589 & 3.059242 & 1.87493 & 0.068 \\
Farm size & -0.0183 & 0.8787802 & 0.04116 & 0.006 \\
Farm income & -0.0000037 & 1.000027 & 0.00001 & 0.126 \\
Market access & -0.3734 & 0.0722422 & 0.05305 & 0.000 \\
Extension service & -0.3094 & 0.1133275 & 0.13179 & 0.0015 \\
Contemplating migration & 0.0032 & 1.02287 & 0.88585 & 0.979 \\
Credit access & 0.1194 & 2.317526 & 2.76966 & 0.482 \\
Market distance & -0.2429 & 0.1809904 & 0.10413 & 0.003 \\
Constant & & 250.7866 & 4305.37 & 0.748 \\
Log likelihood = -52.890026 & & & \\
PseudoR2 = 0.4633 & & & &
\end{tabular}

Source: Field survey, 2015. STATA 13.0 output

\section{Essay Summary and Policy Recommendations}

About a third of the sample (32.67\%) in the Terai region, $27.33 \%$ in the Hill region and $26.66 \%$ in the Mountain region never use irrigation water in crop production. Only $51.78 \%$ of the total respondents in the study area have year-round food security where as $10 \%$ have less than three months of food security from their on-farm activities. 
The survey revealed differences in cropping intensity between farmers who are and are not involved in adaptation practices to manage agricultural water and agronomic practices in all regions. Both cropping intensity and gross margin were not found statistically significant. The results of the study underscore important messages;

- Mixed farming is a successful livelihood strategy that minimizes risks of complete crop failure and hence stabilizes farm revenue; and

- Cereal crops are not profitable; Ceteris paribus, cereal cultivation is not economically feasible in the Mountain and Hill regions because of high water requirements which are hard to meet in the undulated terraced landscape.

This research shows that farmers in all regions prefer collective management of water resources in order to increase the supply of water and improve the equitable distribution of water. Focus group discussion revealed that this type of water governance would help to increase small holders farm output and support more remunerative cropping system selection. Together, the findings that only $46 \%$ of total water demand are fulfilled and that farmers are willing to pay about $73 \%$ more than the current (base) price of water, strongly suggest the need for water resource infrastructure development. This conclusion is similar to that of the International Water Management Institute's recommendation that Nepal invest in water resource infrastructure to improve water availability and access (IWMI, 2010). This will help close the cropping intensity gap (between adaptive and non-adaptive farmers) and boost the regional economy via expanding its irrigable hectares. This in turn would further motivate farmers to develop 
and implement adaptive management strategies to deal with ongoing climatic and environmental changes. In conclusion, if the water supply was expanded to allow irrigation on the remaining $76 \%$ of arable land (MOAD, 2016), livestock and household uses, the Koshi river basin alone could add as much as $46,958 \mathrm{~km}^{2}$ along with a $10 \%$ increment in livestock (herd size) and reduced expenditures of time for household water procurement. A conservative estimate of impacts would be an increase farm outputs of about $11,700 \mathrm{mt}$ of cereal crops (rice, maize, wheat, and barley), 20,000 $\mathrm{mt}$ of vegetables and livestock, worth about NRs. 20-25 millions in the local economy ${ }^{17}$.

Based on survey results, direct field observation and focus group discussions, the following conclusions and recommendations are made:

- Most farmers prefer to work in small groups. Collective management of water resource may be more effective than other institutional arrangements. The size of the community water users groups should be small and within similar socio-cultural populations.

- Monoculture, especially cereal farming in Mountain and Hills are not profitable under the given level of water resource availability.

- Water supply management, such as small scale dams in creeks and rivulets, is required to increase and stabilize the water supply for both agricultural and household purposes in all regions.

\footnotetext{
${ }^{17}$ Calculated based on available cultivable land, productivity difference between irrigated and rain-fed farming and current market structure ( Author's calculation, 2016; Focus group discussion, 2016)
} 
- Financial access, market infrastructure development and government extension services are major factors determining adaptation decision.

- Agricultural extension programs are mostly confined to road accessible areas and not sufficiently staffed in the field. Governments should consider establishing more service centers and subject matter specialists (Horticulturist, Entomologist and Pathologist are high in demand in the field) in order to reach non-adapters and needy farmers. For quality extension, government may work in public private partnership model because commercial farmers are often well updated in the farming system knowhow and could help educate other farmers.

- Research concludes there are discernable effects of climate change on water resource and severe impact on food production and household economy in all ecoregions of Nepal. Socio-economic variables such as extension services, household labor supply, farm income, market access, and distance to market centers are relevant in decision making process for adaptation strategies in the farming communities of Koshi river basin. 


\section{References}

Adams, R. M.; B. H. Hurd; S. Lenhart and N. Leary, 1998. Effects of global climate change on agriculture: an interpretative review, Climate Research, 11: 19-30.

Agrawala S.; Raksakulthai, V.; van Aalst M.; Larsen, P.; Smith, J. and Reynolds, J. 2003 Development and climate change in Nepal: focus on water resources and hydropower. Organization for Economic Cooperation and Development, Paris.

Agresti, Alan. 2007. An introduction to categorical data analysis. Wiley Series in Probability and Statistics. John Wiley and Sons, Inc., New Jersey.

Allen, D. M. and Scibek, J. 2006. Comparing modelled responses of two high permeability unconfined aquifers to predicted climate change. Global and Planetary Change (Netherlands), 50(1-2): 50-62.

Anuchiracheeva, S. and Pinkaew, T. 2009. Jasmine rice in the weeping plain: adapting rice farming to climate change in Northeast Thailand. Oxfam GB, Thailand.

Bastakoti, Ram C.; Joyeeta Gupta; Mukand S. Babel and Meine P. van Dijk. 2014. Climate risks and adaptation strategies in the Lower Mekong River basin. Regional Environ Change, 1491):207-219.

Birkmann, J. 2011. First- and second-order adaptation to natural hazards and extreme events in the context of climate change. Natural Hazards, 58(2):811-840.

Bradshaw, B.; Dolan, H. and Smit, B. 2004. Farm-level adaptation to climatic variability and change: crop diversification in the Canadian prairies. Climate Change, 67(1):119-141. 
Chhetri, N. B. and Easterling, W. E. 2010. Adapting to climate change: retrospective analysis of climate technology interaction in the rice-based farming system of Nepal. Annals of the Association of American Geographers, 100(5):1-21.

Chinvanno, S.; Souvannalath, S.; Lersupavithnapa, B.; Kerdsuk, V. and Thuan, N.T.H. 2008. Strategies for managing climate risks in the Lower Mekong River Basin: a place-based approach. In: Leary, N.; Adejuwon, J.; Barros, V.; Burton, I.; Kulkarni, J. and Lasco, R. (eds) Climate change and adaptation. Earthscan, London, pp 228-246.

Chaudhary, P. and Aryal, K. P. 2009. Global warming in Nepal: challenges and policy imperatives. Journal of Forest and Livelihood, 8 (1):3-13.

Collison, Andrew; Steven, Wade; Jim, Griffiths and Martin, Dehn, 2000. Modelling the impact of predicted climate change on landslide frequency and magnitude in SE England. Engineering Geology, 55: 205-218.

Conceição, Pedro and Yanchun Zhang, 2010. Discounting in the context of climate change economics: the policy implications of uncertainty and global asymmetries. Environmental Economics and Policy Studies, 12: 31-57.

Crozier, M. J. 2010. Deciphering the effect of climate change on landslide activity: A review. Geomorphology, 124: 260-267.

Darwin, Roy; Marinos, Tsigas; Jan, Lewandrowski and Anton, Raneses.1995. World agriculture and climate change. Economic Adaptations Agricultural Economic Report Number 703. US Department of Agriculture Economic Research Service: Washington, DC.

Dawson, R. J.; Ball, T.; Werritty, J.; Werritty, A.; Hall, J. W. and Roche, N. 2011. Assessing the effectiveness of non-structural flood management measures in the Thames 
Estuary under conditions of socioeconomic and environmental change. Global Environ Change, 21:628-646.

Eisenhardt, K. M. 1989. Building theories from case study research. Academy of Management Review, 14(4): 532-550.

Eriksson, M.; Xu, J.; Shrestha, A. B.; Vaidya, R. A.; Nepal, S. and Sandstörm, K. 2009. The Changing Himalayas: Impact of climate change on water resources and livelihoods in the greater Himalayas. Perspectives on water and climate change adaptation. ICIMOD, Kathmandu.

Feder, G.; R. E. Just and D. Zilleberman. 1985. Adoption of Agricultural Innovation in Developing Countries: A Survey. Economic Development and Cultural Change, 33: 255-298.

Foltz, J. D. 2003. The Economic of Water-Conserving Technology Adoption in Tunisia: An Empirical Estimation of Farmer's Technology Choice. Economic Development and Cultural Change, 51:359-373.

Fukai, S.; Pantuwan, G.; Jongdee, B. and Cooper, M. 1999. Screening for drought resistance in rainfed lowland rice. Field Crops Research, 64:61-74.

Gregory, P.; Ingram, J.; Campbell, B.; Goudriaan, J.; Hunt, T.; Landsberg, J.; Linder, S.; Stafford-Smith, M.; Sutherst, R. and Valentin, C. 1999. Managed production systems. The Terrestrial Biosphere and Global Change Implications for Natural and Managed Ecosystems. Cambridge University Press.

Green, William H. 2011. Econometric Analysis. Pearson Education Inc., New Jersey. 
Gujarati, D. N. 2004. Basic Econometrics. Tata McGraw-Hills, New York.

Hall, A. E. 2004. Breeding for adaptation to drought and heat in cowpea. European Journal of Agronomy, 21:447-454.

Hoa, L. T.V.; Nhan, N. H.; Wolanski, E.; Cong, T. T. and Shigeko, H. 2007. The combined impact on the flooding in Vietnam's Mekong River delta of local man-made structures, sea level rise, and dams upstream in the river catchment. Est Coastal Shelf Sci. 71:110-116.

Howden, S. M.; Soussana, J. F.; Tubiello, F. N.; Chhetri, N.; Dunlop, M. and Meinke, H. 2007. Adapting agriculture to climate change. Proc. Natl. Acad. Sci. 104:19691-19696.

IPCC. 2007a. Climate Change 2007: The Physical Science Basis. Contribution of Working Group I to the Fourth Assessment Report of the Intergovernmental Panel on Climate Change [Solomon, S; Qin, D; Manning, M; Chen, Z; Marquis, M; Averyt, KB; Tignor, M; Miller, HL (eds)]. Cambridge and New York: Cambridge University Press.

Isham, J. 2002. The effect of Social capital on Fertilizer Adoption: Evidence from Rural Tanzania. Journal of African Economics. 11:39-60.

Jongdee, B.; Pantuwan, G.; Fukai, S. and Fischer, K. S. 2006. Improving drought tolerance in rainfed lowland rice: an example from Thailand. Agric Wat Management, $80: 225-240$.

Just, Richard E.; Darell L. Hueth, and Andrew S. 2004. The Welfare Economics of Public Policy: A Practical Approach to Project and Policy Evaluation. Edward Elgar, USA. 
Kabat P. and van Schaik SH. 2003. Climate changes the water rules: how water managers can cope with today's climate variability and tomorrow's climate change Dialogue on Water and Climate Netherlands. Access on: www.waterandclimate.org.

Kaphle, Manoj and Keshab K. Dahal. 2014. Accessing Water Resources: A Case Study of Ways to Improve Access of Marginalized Communities to Underutilized Lakes for Fish Farming in Rukum and Kapilbastu Districts, Nepal. Journal of Forest and Livelihood, 12(1):64-74.

Khanal, R. Chandra. 2009. Climate change and organic agriculture. Journal of Agriculture and Environment, 10:100-110.

Kuntiyawichai, K.; Schultz, B.; Uhlenbrook, S.; Suryadi, F. X. and van Griensven, A. 2010. Comparison of flood management options for the Yang River basin, Thailand. Irrigation and Drainage, 60(4):526-543.

Lettenmaier, D. P.; Wood, E. F. and Wallis, J. R. 1994. Hydro-climatological trends in continental United States, 1948-1988. Journal of Climate, 7:586-607.

Liverman, D. 2008. Assessing impacts, adaptation and vulnerability: reflections on the Working Group II Report of the Intergovernmental Panel on Climate Change. Global Environ Change, 18(1):4-7.

Mai, Cong V.; Marcel J. F. Stive and Pieter H. A. J. M. Van G. 2009. Coastal Protection Strategies for the Red River Delta. Journal of Coastal Research, 25(1):105 116.

Malla, G. 2008. Climate change and its implication on Nepalese agriculture. Journal of Agriculture and Environment, 9:62-71. 
Manandhar, S.; Vogt, D. S.; Perret, S. R. and Kazama, F. 2011. Adapting cropping systems to climate change in Nepal: a cross-regional study of farmers' perception and practices. Regional Environmental Change, 11(2):335-348.

Menzel, L.; Thieken, A.; Schwandt, D. and Burger, G. 2006. Impact of climate change on the regional hydrology - scenario-based modeling studies in the German Rhine catchment. Natural Hazards, 38(1): 45-61.

Merrett, S. 2002. Water for Agriculture: Irrigation Economics in International Perspective. Tylor and Francis Inc. USA.

Miller, J. R.; Dixon, M. D. and Turner, M. G. 2004. Response of avian communities in large-river floodplains to environmental variation at multiple scales. Ecological Applications, 14: 1394-1410.

Mirza, M. Q.; Warrick R. A.; Ericksen N.J. and Kenny GJ. 1998. Trends and persistence in precipitation in the Ganges Brahmaputra and Meghna Basins in South Asia. Hydrological Sciences Journal, 43: 845-858.

Naess, L. O.; Bang G.; Eriksen S. and Vevatne J. 2005. Institutional adaptation to climate change: flood responses at the municipal level in Norway. Global Environ Change, 15:125-138.

Ngigi, S.N.; Thome, J.N.; Waweru, D. W.and Blank, H. G. 2000. Technical evaluation of low-head drip irrigation technologies in Kenya.research report. Nairobi University and the International Water Management Institute, Nairobi.

Panta, Krishna Prasad. 2012. The Journal of Agriculture and Environment, 13: 919. 
Paudel, B.; S. Acharya; R. Ghimire; K. R. Dahal and P. Bista. 2014. Adapting Agriculture to Climate Change and Variability in Chitwan: Long-Term Trends and Farmers' Perceptions. Agricultural Research, 3(2):165-174.

Plate, E. J. 2007. Early warning and flood forecasting for large rivers with the lower Mekong as example. Journal of Hydro- Environment Research, 1(2): 80-94.

Polley, H.W. 2002. Implications of atmospheric and climatic change for crop yield and water use efficiency. Crop Science, 42:131-140.

Porfir'ev, B. N. 2011. Climate Change and Economics. Herald of the Russian Academy of Science, 81 (2): 114-126.

Pradhan, N. S. ; Khadgi, V.; Schipper, L; Kaur, N; and Geoghegan, T. 2012. Role of Policy and Institutions in Local Adaptation to Climate Change: Case studies on responses to too much and too little water in the Hindu Kush Himalayas. Kathmandu, ICIMOD.

Reynard, N. S.; Prudhomme C. and Crooks, S. M. 1998. The potential impacts of climate change on the flood characteristics of a large catchment in the UK. Proceedings of the Second International Conference on Climate and Water Espoo Finland August 1998. Helsinki University of Technology, Helsinki, Finland.

Risby, J. S. and Entekhabi D. 1996. Observed Sacremento Basin streamflow response to precipitation and temperature changes and its relevance to climate impact studies. Journal of Hydrology, 184(3-4): 209-223.

Rosenzweig, C. and Hillel D. 1995. Potential impacts of climate change on agriculture and food supply, U.S. Global Change Research Information Office, Washington, DC. 
Rossi, G.; Cancelliere, A. and Giuliano, G. 2005. Case study: Multicriteria assessment of drought mitigation measures. Journal of Water Resources Planning and Management, 131(6):449-457.

Rowley, J. 2002. Using case studies in research. Management Research News, 25(1): $16-27$.

Sandstrom, K. 1995. Modeling the effects of rainfall variability on ground water recharge in semi-arid Tanzania. Nordic Hydrology, 26: 313-330.

Schiermeier, Q. 2008. Water: a long dry summer. Nature, 452: 270-273.

Selvaraju R. 2003. Impact of El-Nino-southern oscillation on Indian foodgrain production. International Journal of Climatology, 23(2): 187-206.

Sharma, P.; Dhanjit, Deka and Ranjan Saikia. 2011. An analysis of changing land use pattern and its effects on Umtrew Basin, Northeast India. Hungarian Geographical Bulletin, 60 (1): 67-78.

Sharma, K. P. 1993. Role of Meltwater in Major River Systems of Nepal. In Young, G.J. (ed) International Symposium on Snow and Glacier Hydrology, Kathmandu, International Association of Hydrological Sciences, Publication No. 218, pp 113 - 122. Wallingford (UK): IAHS.

Sinha, S. K. 1997. Global change scenario: current and future with references to land cover change and suitable agriculture-south East Asian context. Current Science, 72(11):846-854.

Smit, B. and Skinner, M. W. 2002. Adaptation options in agriculture to climate change: a typology. Mitigation and Adaptation Strategies for Global Change, 7:85-114. 
Tao, F; Yokozawa, M. and Hayashi, Lin E. 2005. A perspective on water resources in China: interactions between climate change and soil degradation. Climatic Change, 68(1): 169-197.

Thapa, Sridhar and Joshi, Ganesh R. 2010. A Ricardian analysis of the climate change impact on Nepalese agriculture. Available at MPRA: http://mpra.ub.unimuenchen.de/29785/ accessed on: April 13, 2015.

Turner, R. Kerry; Stavros Georgiou; Rebecca Clark; Roy Brouwer and Jacob Burke. 2004. Economic valuation of water resources in agriculture: From the sectoral to a functional perspective of natural resource management. Vol. 27. Food \& Agriculture Organization.

Turral, H.; Svendsen, M. and Faures, J. M. 2010. Investing in irrigation: Reviewing the past and looking to the future. Agricultural Water Management, $97(4): 551-560$.

UN/ISDR. 2004. Inter-Agency Secretariat of the International Strategy for Disaster Reduction. Living with Risk - A global review of disaster reduction initiatives.

Valentin C. 1996. Soil erosion under global change. Global Change and Terrestrial Ecosystems. Cambridge University Press: Cambridge. Vapnik VN. 1995. The Nature of Statistical Learning Theory. Springer: New York.

Vicente-Serrano, S. M. and Lopez-Moreno Juan I. 2006. The influence of atmospheric circulation at different spatial scales on winter drought variability through a Semi-Arid Climatic Gradient in Northeast Spain. International Journal of Climatology, 26(11): 1427-1453. 
WECS. 2011. National water plan. Kathmandu: His Majesty's Government of Nepal, Water and Energy Commission Secretariat (WECS). Kathmandu, Nepal.

Wilkinson, P. L.; M. G. Anderson and D. M. Lloyd, 2002. An integrated hydrological model for rain-induced landslide prediction. Earth Surface Processes and Landforms, 27(12): 1285-1297.

Yaning, C.; Kuniyoshi T.; Changchun X.; Yapeng C. and Zongxue X. 2006. Regional climate change and its effects on river runoff in the Tarim basin China. Hydrological Processes, 20:2207-2216.

Yin, R. K. 1994. Case study research: design and methods. 2nd edition. Thousand Oaks, CA: Sage.In: Jennifer Rowley. 2002. Using case studies in research. Management Research News, 25(1): $16-27$. 


\section{ESSAY 3: Water Use Efficiency and Its Determinants in Three Ecoregions of Nepal}

\section{Research Background}

In economics, efficiency is defined as the relationship between outputs and inputs and is calculated as the slope of the functional relationship in the case of marginal efficiency. In the case of agriculture, the relevant outputs in the analysis include crop production measured as total biomass or grain yield whereas inputs include water use. Water productivity can be classified into two broad categories; physical water productivity (ratio of mass of product to the amount of water consumed) and economic water productivity ('monetary value' derived per unit of water used). The particular definition of efficiency used depends on the application and data availability (Sadras et al. 2007). In the context of water resources, efficiency can also be expressed from the viewpoint of engineering and irrigation such as conveyance efficiency.

Agricultural water use efficiency can broadly be considered a measure of a cropping system's ability to convert water into plant biomass. In addition to irrigation water, water use efficiency (WUE) considers water stored in the soil and rainfall during the growing season. Water use efficiency in agriculture mostly relies on the soil's ability to capture and store water, the crop's ability to access water stored in the soil and convert it to biomass, and rainfall during the growing season. Last but not least, farm management skills such as fertilizer management, weeding, production planning are also 
equally important influences on WUE. WUE can best be understood from the production function that relates economics of water allocation in farming system management. WUE is an indicator that can be used to evaluate economic returns from alternative uses of water resources. Water productivity is the ratio of the difference between irrigated to rainfed crop yield $(\Delta \mathrm{Y})$, and the amount of applied irrigation water, symbolically, Water productivity $=\frac{\Delta\left(Y_{I}-Y_{R}\right)}{W}\left(\right.$ Grassini et al. 2011), measured as $\mathrm{kgm}^{-3}$. Where, $\mathrm{Y}_{\mathrm{I}}$ and $\mathrm{Y}_{\mathrm{R}}$ are crop output under irrigated and rainfed conditions respectively.

Zwart and Bastiaanssen (2004) report global measured average crop water productivity (CWP) values of $1.09,1.09$ and $1.80 \mathrm{kgm}^{-3}$ for wheat, rice, and maize respectively and suggest the potential for maintaining or increasing agricultural production with 20-40\% less water resources. Zwart and Bastiaanssen (2004) finds that CWP can be increased significantly even in the reduced level of irrigation water used at high altitude. Siddique et al. (1990) determined that old cultivars have lower CWP compared to newly released cultivars but that there was no significant difference in total biomass production between the two cultivars. The new cultivars produce more grain relative to the amount of biomass. Increased CWP is observed in newly developed paddy cultivars due to a higher ratio of photosynthesis to transpiration and due to a shortening growth period (Peng et al., 1998; Tuong, 1999). Grismer (2002) conducted a CWP study of irrigated cotton cultivation in California and Arizona and found higher CWP values with newly developed cultivars than previous findings. This experimental research shows the potential for improving water use efficiency by integrating agronomical efforts (varietal improvement) and better farm management behavior (resources 
management). Kijne et al. (2003b) emphasized that the above efforts should be integrated at plant, field and agro-ecological levels. Some strategies such as mixed cropping, drought tolerant varietal selection, reduced water use irrigation techniques (drip or sprinkle), planting time adjustment etc, are appropriate.

\section{Research Problem and Rationale of the Study}

Nepal has not tapped the major river systems, which discharge substantial amount of water even during the dry season, for irrigation development due to technical and financial constraints. In order to improve agriculture productivity and the management of selected irrigation schemes ${ }^{18}$, the Irrigation and Water Resources Management program was implemented in Nepal during the last decade. This program is expected to enhance institutional capacity for integrated water resources management. The key challenges in irrigation development in Nepal are old infrastructure, poor performance of the existing irrigation systems, weak participation of Water Users Associations (WUAs) and weak linkages between production and markets.

Climate change is posing a serious threat to both low and high altitude farms and communities. It threatens assets such as ground water, forestry, livestock, wildlife, and permafrost and social issues such as food security, migration, land-use patterns and culture. Effects of climate change on water resources vary both spatially and temporally. Panta (2012) finds that a rise in minimum temperature decreases the productivity of rice

\footnotetext{
${ }^{18}$ Two broad categories: farmer-managed irrigation systems (FMIS) and Agency Managed Irrigation System (AMIS)
} 
via reduced level of water availability in the paddy field. That poses a great threat to food security especially in the Hill and Terai regions of Nepal. Analysis of Nepalese agriculture shows that climate variables have significant impact on the net farm income per unit of area (Thapa and Joshi, 2010). It will also have important income distribution implications. Conceição and Zhang (2010) point out the effects of climate change in tropical regions will be overwhelmingly negative.

Lowland agriculture, receives water for irrigation from the Himalayan glacier system, which is expected to suffer negatively from lack of water in the dry season. The estimated glacial melt water contribution is, for example, 20 to $40 \%$ in rivers in Western China (Tao et al., 2005), equivalent to or greater than 50\% in the Indus (Tarar, 1982), and $30 \%$ in the Nepalese river during the pre-monsoon season (Sharma, 1993). IPCC (2007a) projects that for every $1{ }^{\circ} \mathrm{C}$ rise in temperature, agricultural water demand increases by 6 to $10 \%$ or more. This is expected to cause a $4-10 \%$ decrease in cereal production in South Asian countries by the end of this century. Decreased production of this magnitude ultimately may lead to widespread food insecurity and lower living standards especially for the most vulnerable members of society.

Water scarcity will be a major constraint on the production of food required to meet the local and global food demand in the future (Erickson et al. 2009; Rosul, 2014). The scarcity of usable water is further worsened by climate change. Water shortages have global causes yet local effects, especially in the high Himalayan region. It is important to investigate, quantify and find better ways to improve water use efficiency in agricultural 
practices. Fresh water obtained from the melting of the Himalayan glacier is one of the main sources of freshwater reserves. Immerzeel et al. (2010) projects declining water availability will threaten the food security of some 70 million people in south-Asia (Table $1)$.

Table 1. Characteristics of major river basins and food insecurity by 2050 in the South Asian region

\begin{tabular}{lllll}
\hline Parameter & Indus & Ganges & Brahmaputra & Yangtze \\
\hline Irrigation water demand (mm/yr) & 908 & 716 & 480 & 331 \\
Food insecure people (millions) & $26.3 \pm 3$ & $2.4 \pm 0.2$ & $34.5 \pm 6.5$ & $7.1 \pm 1.3$ \\
\% decrease in mean upstream water supply & 8.4 & 17.6 & 19.6 & 5.2 \\
Annual mean discharge(m3/sec)* & 5533 & 12037 & 21261 & 28811 \\
$\%$ of glacier melt in river flow* & Up to 50 & $\sim 9$ & $\sim 12$ & $\sim 18$ \\
\hline
\end{tabular}

Source: Immerzeel et al. (2010); *Erickson et al. (2009)

South Asia currently faces challenges allocating sufficient water for agriculture to feed its increasing population. Water demand is growing even as the supply is constant or declining. A prominent feature of the nexus of water-agriculture-climate change in South Asia is the high degree of dependency of downstream communities on upstream ecosystem services for water quality especially for dry-season irrigation flow (Rosul, 2014). The need for improved water resource use efficiency is unavoidable if the region is to adjust to the changing environment. 


\section{Theoritical Framework}

\subsection{Irrigation Management}

It is widely accepted that productivity is a measure of system performance expressed as a ratio of output to input. Kijne (2003) used the concept of water productivity as a robust measure of the ability of agricultural systems to convert water into food and defined WP as

$$
W P=\frac{\text { Agricultural Benefit }}{\text { Water Use }}
$$

Generally WP is measured in units of $\mathrm{kg} / \mathrm{m}^{3}$. If production is measured in $\mathrm{kg} / \mathrm{ha}$, water use is estimated as mm of water applied or received as rainfall, convertible simply to $\mathrm{m}^{3} / \mathrm{ha}$. Water productivity provides robust insight into the opportunities for redistribution of water within river basin among different farming system in space and time. A farmer can estimate the amount of water requirements of a field for surface irrigation systems using the equation (Martin, 2006):

$$
Q * T=D * A
$$

Where $\mathrm{Q}$ is the rate of irrigation water flow (in cubic feet per second); $\mathrm{T}$, total time of irrigation (hours); D, depth of water applied (inches) and A represents irrigated area (acre). Irrigation intake rate of soil is a multivariate function affecting the water efficiency in the farming system (Zhang et al. 1995; Wang and Shangguan, 2015).

$$
I=f(S T, S S, S O, S F, T, C C)
$$


I is the irrigation intake rate of soil; ST is the soil texture; SS is the soil structure; $\mathrm{SO}$ is the organic matter in soil; $\mathrm{SF}$ is the slope of farmland; $\mathrm{T}$ is the temperature of the growing season and $\mathrm{CC}$ is the characteristics of crop itself. Temperature during the crop cycle and specific characteristics of the standing field crops are crucial factors in estimating the crop evapotranspiration. Crop evapotranspiration can best be measured with the equation (Cook et al. 2006):

$$
E=S M+I R+R+C-I-R F
$$

Where, E is the crop evapotranspiration, SM is the soil moisture, IR is the irrigation applied, $R$ is the rainfall, $C$ is capillary rise (from the water table to the crop root zone), I is the downward infiltration, and RF is the surface runoff. However, Zhang et al. (1995) estimates that capillary rise is almost negligible in water table below $5 \mathrm{~m}$. Until recently, water efficiency has been viewed and analyzed in different ways. Frenken and Faurès (1997) developed the following relationship to measure crop water requirements (CWR) for a given crop $i$ as

$$
C W R_{i}=\sum_{t=0}^{T}\left(K C_{i, t} * E T_{i, t}-P_{e f f, t}\right) \quad \text { measured in millimeter (mm). }
$$

Where $\mathrm{KC}_{\mathrm{i}}$ is the crop coefficient of the given crop i during the growth stage $\mathrm{t}$ and where $\mathrm{T}$ is the final growth stage, ET is the evapotranspiration and $\mathrm{P}$ is the precipitation. Each crop has its own water requirements. Net irrigation water requirements (NIWR) in a specific irrigation scheme for a given year are thus the sum of individual crop water requirements $\left(\mathrm{CWR}_{\mathrm{i}}\right)$ calculated for each irrigated crop i. "Multiple 
cropping (several cropping periods per year) is thus automatically taken into account by separately computing crop water requirements for each cropping period" (Frenken and Faurès (1997, PP: 34).

$N I W R=\frac{\sum_{i=1}^{n} C W R_{i} * S_{i}}{S}$ measured in millimeter $(\mathrm{mm})$ or $\mathrm{m}^{3} / \mathrm{ha}\left(1 \mathrm{~mm}=10 \mathrm{~m}^{3} / \mathrm{ha}\right)$

Where $S_{i}$ is the area cultivated with the crop $i$ in ha. Net Irrigation Water Requirement (NIWR) when added to conveyance efficiency of the irrigation system which is explained in equation in the analytical section gives gross irrigation water requirement (GIWR). GIWR is the amount of water to be extracted (by diversion, pumping) and applied to the irrigation scheme. GIWR $=\frac{1}{E} * N I W R$; measured in millimeter (mm). Where $\mathrm{E}$ is the conveyance efficiency.

\subsection{The Theory of Economic Rent}

Theoretically, a single product firm will seek to maximize net rent $(\mathrm{R})$ defined as:

$$
R=\left(P_{y} . Y\right)-\sum_{i=1}^{n}\left(X_{i} \cdot P_{x i}\right)
$$

Where $\mathrm{YP}_{\mathrm{y}}$ is gross revenues from the sale of products and $\mathrm{P}_{\mathrm{xi}}$ is the price of the $\mathrm{i}^{\text {th }}$ input $\left(\mathrm{X}_{\mathrm{i}}\right)$ and $\mathrm{Y}$ is the output produced with inputs $\mathrm{X}_{\mathrm{i}}$. The value of water in agricultural production is $\mathrm{R}$ evaluated with and without adequate water. With less than optimal water, the rent is 


$$
R_{0}=\left(P_{y} \cdot Y_{0}\right)-\sum_{i=1}^{n}\left(X_{i 0} \cdot P_{x i}\right)
$$

While with an adequate supply of water it is

$$
R_{1}=\left(P_{y} \cdot Y_{1}\right)-\sum_{i=1}^{n}\left(X_{i 1} \cdot P_{x i}\right)
$$

From equation 5 and 6 it is possible to evaluate an optimum increment in water application in agricultural production, that is, the change in net rent $(\Delta R)$.

$$
\begin{aligned}
& \Delta R=R_{1}-R_{0} \\
& \Delta R=\left[\left(P_{y} \cdot Y_{1}\right)-\sum_{i=1}^{n}\left(X_{i 1} \cdot P_{x i}\right)\right]-\left[\left(P_{y} \cdot Y_{0}\right)-\sum_{i=1}^{n}\left(X_{i 0} \cdot P_{x i}\right)\right]
\end{aligned}
$$

Equation 7 produces two types of information; first, how much farm income is possible with changes in input combinations and/or incremental water supply, and second, an estimate of economic efficiency of increasing water on-site (via irrigation provision). Dividing both sides of equation 7 by $\Delta W$, one can impute on-site value or net income per unit of water (Young and Loomis, 2014).

$$
\frac{\Delta R}{\Delta W}=\frac{\left[\left(P_{y} \cdot Y_{1}\right)-\sum_{i=1}^{n}\left(X_{i 1} \cdot P_{x i}\right)\right]-\left[\left(P_{y} \cdot Y_{0}\right)-\sum_{i=1}^{n}\left(X_{i 0} \cdot P_{x i}\right)\right]}{\Delta W}
$$

Any increase in productivity of water will reflect positively on the productivity of farming systems (Fig. 1). 


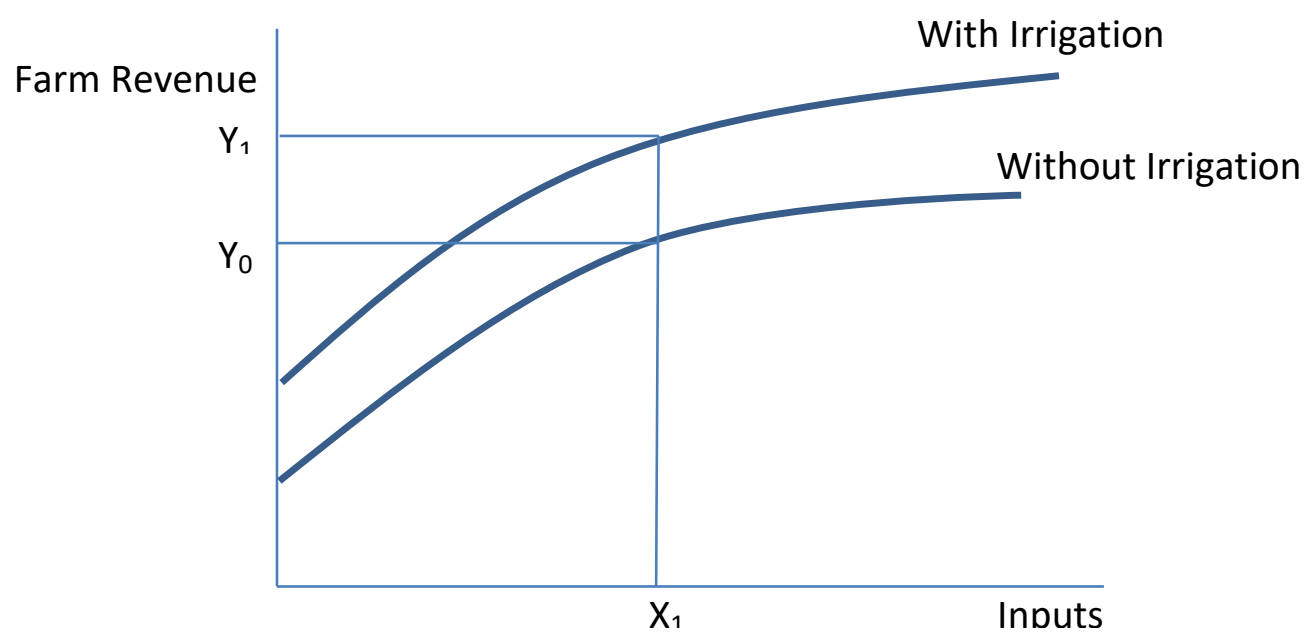

Fig.1 Hypothesized effect of water on

\section{Analytical Approach}

FAO describes various terminologies ${ }^{19}$ regarding water management. This research uses water conveyance efficiency, water application efficiency, irrigation efficiency and crop water use efficiency to understand and measure sustainable water resource planning.

${ }^{19}$ Crop consumptive water use: The total water used for evapotranspiration and cell construction from planting to harvest for a given crop in a specific climate regime (Perry et al., 2009). Crop irrigation water requirement: Consumptive use minus effective precipitation (FAO/IPTRID/ICID/ODA, 2012, Irrigation Guidelines, Land and Water Digital Media Series 12, \& FAO, 2000, Handbook on Pressurized Irrigation Techniques). Irrigation water requirement: The quantity of water exclusive of precipitation and soil moisture. Net irrigation water requirement: The water that must be supplied through the irrigation system to ensure that the crop receives enough water for its normal crop production (irrigation consumptive water use + flooding of paddy fields + salt leaching). This does not include losses that are occurring during conveyance, distribution and field application (Savva and Franken, 2002). 
As soon as water resources become limited in supply, efficient use of irrigation water becomes essential to maximize farm income. This situation requires suitable methods of measuring and evaluating how efficiently irrigation water is used to produce crops. Crops are stressed and the yield is affected when water is inadequate while excess water can result in non-point source pollution of water resource due to runoff, leaching and soil erosion (Irmak et al. 2011). In general, water use efficiency is defined from various perspectives. University of Nebraska Lincoln Extension (2011) defined irrigation efficiency from three points of view:

- irrigation system performance

- uniformity of water application, and

- response of crops to irrigation.

This research emphasizes mainly agronomic and economic aspects of efficiency. The former explains the yield objectives while the latter is related to financial returns obtained from irrigation in relation to investment made in water resource management. The costs and prices vary from year to year and fluctuate widely from place to place (Hillel, 1997). Wider ranges of socio-ecological systems play vital roles in sustainability and efficiency of resource management under the pressure of climate change (Ostrom, 2007). Of the various irrigation efficiency estimation tools, the followings are the most relevant in this study.

Water conveyance efficiency: Irrigators normally deliver the water from its sources to the crop area through natural drainage (earthen or lined canals). Water loss between the source and at-site is unavoidable because of seepage, spills, evaporation, 
leaks, etc. Conveyance efficiency can be estimated as the ratio of the net amount of water at-site to amount of water diverted at-source (Hillel, 1997).

$$
W C E=\left(V W_{f} / V W_{s}\right) * 100
$$

Where

$\mathrm{WCE}=$ water conveyance efficiency $(\%)$

$\mathrm{VW}_{\mathrm{f}}=$ volume of irrigation water at-site/field

$\mathrm{VW}_{\mathrm{s}}=$ volume of water diverted at-source

Crop water use efficiency: This measures the irrigation effectiveness in terms of crop productivity. Irmak et al. (2011) defined this aspect of efficiency as the ratio of the mass of economic yield per unit of irrigation water used.

$$
C W E=\left(C Y_{i}-C Y_{d}\right) /\left(E T_{i}-E T_{d}\right)
$$

$\mathrm{CWE}$ is the crop water use efficiency, $\mathrm{CY}_{\mathrm{i}}$ is the yield of the irrigated crop, $\mathrm{CY}_{\mathrm{d}}$ is the yield for an equivalent rainfed crop, and $\mathrm{ET}_{\mathrm{i}}$ and $\mathrm{ET}_{\mathrm{d}}$ are crop evapotranspiration for irrigated and rainfed crop respectively. Alternatively, crop-water use efficiency is the marketable crop produced per unit volume of water (Hillel 1997). Hillel summarizes in a single concept, the overall agronomic efficiency of water use:

$$
E_{a}=P / W
$$

$\mathrm{P}$ is the marketable product harvest $(\mathrm{kg})$ and $\mathrm{W}$ is the volume of water used $\left(\mathrm{m}^{-3}\right)$. We calculated water used (irrigation water) for crops grown (rice, wheat and corn) and 
their harvested grain which is marketable in a year in the selected sample farm in all ecoregions (study areas).

$\mathrm{E}_{\mathrm{a}}$ can be interpreted from an economic sense. Marketable products can be valued with the given market price of the respective crop. Molden et al. (2001) observed some cases of water productivity in economic terms such as US $\$ 0.3 / \mathrm{m}^{3}$ for potatos to US $\$ 0.03 / \mathrm{m}^{3}$ for wheat in South Asia, US $\$ 0.03 / \mathrm{m}^{3}$ (in India) to US $\$ 0.91 / \mathrm{m}^{3}$ (in Burkina Faso). The values for wheat production ranged from US $\$ 0.07$ to $0.17 / \mathrm{m}^{3}$. However, Barker et al (2003) and Rogers et a. ( 2002) finds that water productivity in economic terms using price policies to promote the economic productivity of water requires significant government intervention in order to ensure that equity of access to water (public-good case ) are covered adequately.

Finally the overall agronomic efficiency of water use $\left(E_{a}\right)$ value obtained from equation 11 is regressed on various socio-economic and farm characteristics to explore the factors affecting crop-water use efficiency in three ecological regions estimated with two regression models- Ordinary Least Square (OLS) and Tobit regression. The reason for employing 2 models was to assess the robustness of the functional relationship between various important farms related socio-economic parameters and agricultural water use efficiency. The independent variables were the same in both models. The regular numerical values obtained from equation 11 were regressed directly with socioeconomic factors in OLS. In the Tobit function, the efficiency scores obtained from the same equation were first censored in 2 categories. Efficiency values above the sample 
mean value were treated as efficient and below average value were treated as inefficient. Then this is the dependent variable in the Tobit function which regressed with socioeconomic parameters.

Descriptions of the OLS and Tobit function (estimation) are presented in equations 12 and 13 respectively.

$$
\begin{aligned}
& E_{a}=\beta_{0}+\sum_{i=1}^{9} \beta_{i} Z_{i}+u \\
& E_{a}(\text { censored })=\beta_{0}+\sum_{i=1}^{9} \beta_{i} Z_{i}+u
\end{aligned}
$$

Where the $\mathrm{Z}_{\mathrm{i}}$ are age, education, household size, farm size, distance to water source, adaptation of technology, government extension support, credit access and distance to nearby agricultural market(s). $\beta$ is a vector of unknown parameters and $u$ is an independently and identically distributed normal random variables with zero means and common variances, $\sigma^{2}$ as; $\mathrm{u} \sim \operatorname{iidN}\left(0, \sigma^{2}\right)$.

The dependent variable in the OLS regression equation is agronomic efficiency of water use $\left(\mathrm{E}_{\mathrm{a}}\right)$ expressed as $\mathrm{Kg} / \mathrm{m}^{-3}$ and $\mathrm{E}_{\mathrm{a}}$ (censored in two categories- above and below the mean value of agronomic efficiency of water) is the dependent variable in the Tobit regression. Explanatory variables are similar in both models. These are age, education, household size, farm size, distance to water source, technology adaptation, access to extension service, access to credit, and market distance. We expect that educated farm manager with more years of farming experience would be able to adapt quickly because 
of their capacity for learning, and their experience with irrigation water management in different types of farming systems and will have a positive effect on efficiency. Larger household size with adults (of economically active age) are also expected to produce a positive coefficient because they are less likely to have insufficient labor to manage water resources (water source cleaning, seasonal canal construction, equipment cleaning, etc.). Farms with better access to a market center should have a greater incentive to manage water resource and uses water in effective ways to maximize the farm output for market. Since more distance between the farm and a market center means higher transportation costs and possibly higher marketing loss (damage to fresh products) this will reduce the farm revenue and reduce the incentive to use water efficiently. We expect that access to extension services will provide farmers with the information and technical assistance they need make adaptations and to use water more efficiently. Those farmers with access to credit will not have a financial barrier to investing in irrigation management infrastructures to enhance water use efficiency. These may include seasonal water tapping pond construction, water pump installation in the farm lands etc.

\section{Results and Discussions}

\subsection{Descriptive Statistics}

The three major dominant soil types are sandy loam, silt and sand. About $14 \%$ of the respondents in the Terai region farm on sandy soils, which was deposited after the devastating flood in 2006. Average percentage of farms on sandyloam, silt and sand in Mountain are $94.72 \%, 0.29 \%$ and $4.98 \%$, respectively. In the Hill region, these same 
shares are $97.49 \%, 1.46 \%$ and $1.04 \%$, respectively. In the Terai region, the percentages are $77.34 \%, 1.06 \%$ and $21.59 \%$, respectively. Flooding has been a significant cause for land degradation and sand deposition. Focus group discussions and discussions with senior citizens reveal that desertification (conversion of arable land to sand dunes) is increasing.

The Hill region has been under tremendous pressure from forest clearing to facilitate agriculture. Public forest degradation especially in the lower parts of the Hill region has resulted in dysfunctional small scale watersheds within last 10-12 years. Major reasons observed were land area encroachment for resident and farming by landless community members and industry landfill. The region also receives less precipitation which led to small watershed dysfunctional.

There is a difference in cropping intensity between irrigated and unirrigated farm conditions. About a third of the sample (32.67\%) in the Terai, $27.33 \%$ in Hill and 26.66 $\%$ in Mountain region never use irrigation water in crop production. Increased cropping intensity is a desired condition for maximizing farm output and farm revenue in the smallholders communities. Average Cropping intensity ${ }^{20}$ in the study area is $242 \%$ and $150 \%$ in irrigated and unirrigated conditions respectively (Table 2).

\footnotetext{
${ }^{20}$ Cropping intensity is the ratio of effective crop area harvested to the physical area. The cropping intensity may exceed $100 \%$ if more than one crop cycle is completed in a year on the same farm-area. Symbolically, it is defined as $\frac{\sum_{i=1}^{n} A_{i}}{A}$ where $\mathrm{A}_{\mathrm{i}}$ is the area cultivated with the crop $\mathrm{i}$ and $\mathrm{A}$ is the available cultivable area (Frenken and Faurès, 1997)
} 
Table 2. Cropping intensity (ratio) in three ecological belts of the study area

\begin{tabular}{lllll}
\hline \multirow{2}{*}{$\begin{array}{l}\text { Irrigation } \\
\text { conditions }\end{array}$} & \multicolumn{3}{c}{ Ecological regions } \\
\cline { 2 - 4 } & Mountain & Hill & Terai & 2.42 \\
\hline Irrigated & 2.11 & 2.2 & 2.95 & 1.5 \\
Unirrigated & 1.39 & 1.50 & 1.62 &
\end{tabular}

Source: Field Survey, 2015; Focus Group Discussion, 2015

In all regions, water conveyance efficiency (WCE) improvement is a basic step to allocate scarce water resource efficiently. Contrary to the perception that WCE in Terai would be higher than in the high altitude and undulated landscape, farmers are relatively effective in reducing water loss between sources and sites in Mountain, followed by Hill and Terai regions (Table 3). There is very wide variation between maximum and minimum value of water conveyance efficiency in the Terai. Very low (minimum value), 0.01 in the Terai indicates that very poor people who have small holdings in fords (sand area) could improve conveyance efficiency. The overall agronomic efficiency which measures biomass production per unit (volume) water used is presented in table 4. About $75 \%$ of the respondents are in the lowest levels of agronomic performance. Most of them coincide with lower level of conveyance efficiency. Average value of agronomic efficiency is higher in the Mountain $\left(204.4 \mathrm{kgm}^{-3}\right)$ followed by Terai $\left(138.1 \mathrm{kgm}^{-3}\right)$ and Hill (90.4 $\left.\mathrm{kgm}^{-3}\right)$, respectively (Table 4). 
Table 3. Water Conveyance Efficiency ${ }^{21}$ (WCE) in different eco-regions

\begin{tabular}{llll}
\hline Efficiency Level & Mountain & Hill & Terai \\
\hline$\leq 0.50$ & $40(26.67)$ & $41(27.33)$ & $49(32.67)$ \\
$0.51-0.60$ & 0 & 0 & 0 \\
$0.61-0.70$ & $4(2.67)$ & 0 & 0 \\
$0.71-0.80$ & $35(23.33)$ & $55(36.67)$ & $59(39.33)$ \\
$0.81-0.90$ & $71(47.33)$ & $54(36)$ & $38(25.33)$ \\
$0.91-1.00$ & 0 & 0 & $4(2.67)$ \\
Total & 150 & 150 & 150 \\
Mean & 0.61 & 0.594 & 0.54 \\
Standard Deviation & 0.372 & 0.367 & 0.383 \\
Maximum & 0.941 & 0.93 & 1 \\
Minimum & 0.11 & 0.13 & 0.01 \\
\hline
\end{tabular}

Source: Field Survey, 2015. Value in the parenthesis indicates \%

Table 4. Overall agronomic water use efficiency (WUE) of farms in three eco-regions

\begin{tabular}{llll}
\hline Efficiency Level & Mountain & Hill & Terai \\
\hline$\leq 100$ & $107(71.33)$ & $108(72)$ & $122(81.33)$ \\
$101-500$ & $19(12.67)$ & $39(26)$ & $14(9.33)$ \\
$>500$ & $24(16)$ & $3(2)$ & $14(9.33)$ \\
Total & 150 & 150 & 150 \\
Mean & 204.4 & 90.46 & 138.1 \\
Standard Deviation & 396.4 & 119.66 & 262.4 \\
Maximum & 2087 & 616.43 & 1424.65 \\
Minimum & 6.28 & 16.96 & 38.61 \\
\hline
\end{tabular}

Source: Field Survey, 2015. Value in the parenthesis indicates \%

${ }^{21}$ It is the biomass production to the given level of water at site; $\mathrm{kgm}^{-3}$ 


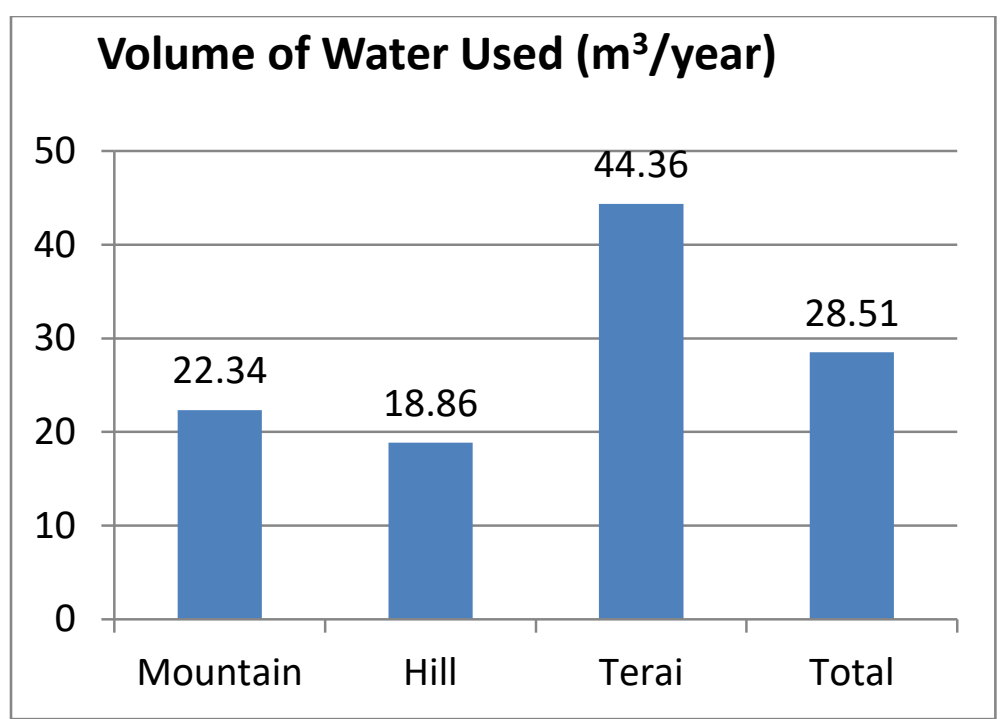

Figure 2. Average Agricultural Water Consumption ( $\mathrm{m}^{3} /$ year)

The survey indicated that the average farm size in Mountain, Hill and Terai are 15.69, 12.6 and 25.34 Ropani respectively. Distance from home to river is twice as far for the Terai population. People in the Terai use more than twice the amount of water in crop production than in the Hill region (Fig. 2). Household water cost in Terai, Hill and Mountain is $0.11,0.26$ and $0.21 \mathrm{Rs} /$ Lit respectively. Because of limited sources and long distance to travel for collecting household water, drinking water is twice as expensive in the Hill region when compared to the Terai region. Only a small fraction of total population has access to year round irrigation. Of the total, $65 \%, 91 \%$ and $79 \%$ of the respondents in Mountain, Hill and Terai have no irrigation in the study area (Figure 3). In aggregate, only about $55 \%$ of respondents have been able to irrigate their land in the rainy season (Figure 4). 


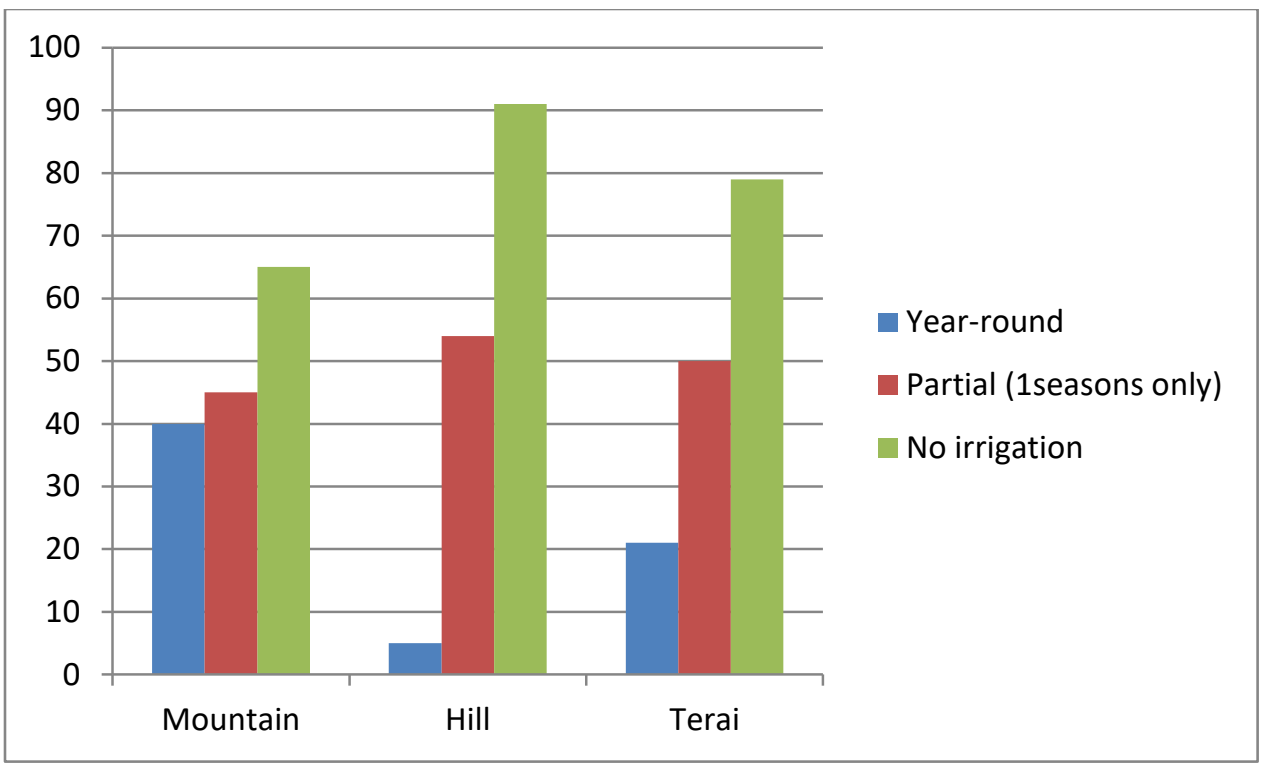

Figure 3. Percentage distribution of irrigation status in the study areas

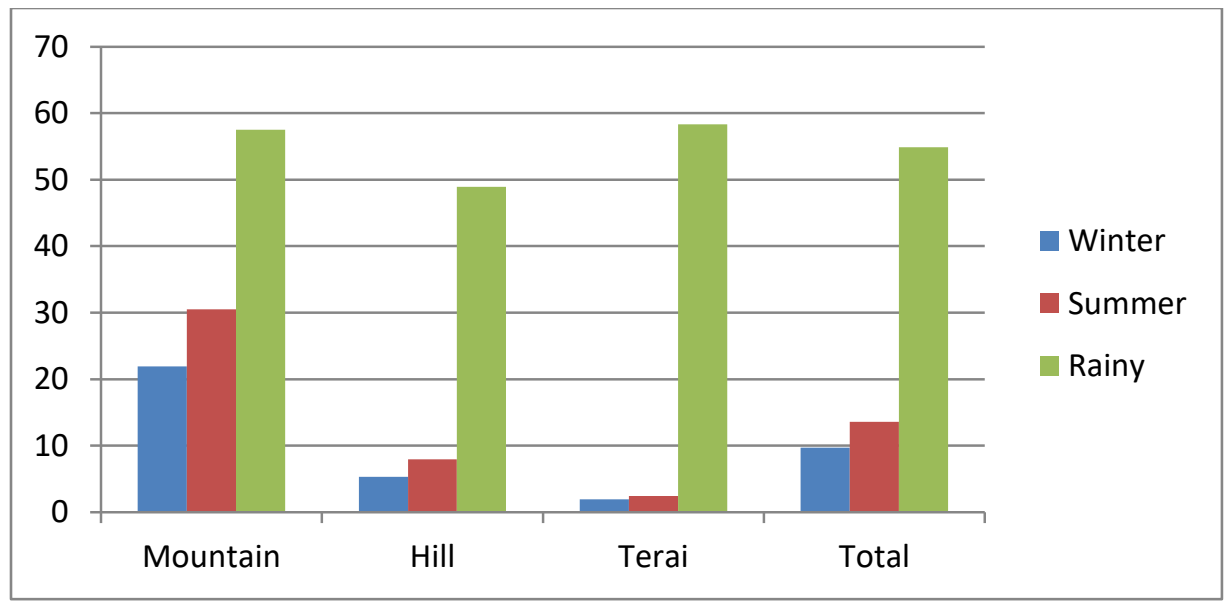

Figure 4. Average percentage of land cover under irrigation in three major seasons 
Table 5. Economic indicators for irrigated and unirrigated conditions

\begin{tabular}{lllllll}
\hline Indicators & \multicolumn{2}{c}{ Mountain } & \multicolumn{2}{c}{ Hill } & \multicolumn{2}{c}{ Tearai } \\
\cline { 2 - 7 } & Irrigated & Unirrigated & Irrigated & Unirrigated & Irrigated & Unirrigated \\
\hline Gross margin (GM) & 86.933 & 51.846 & 56.884 & 19.672 & 82.843 & 40.633 \\
B/C ratio & 3.338 & 2.112 & 2.47 & 1.761 & 1.97 & 2.14 \\
\hline
\end{tabular}

Source: Field Survey 2015

Gross margin (GM) analysis of the agricultural farm shows that farms operating under irrigated conditions in the Hill and Terai regions have more than twice the GM compared to unirrigated conditions (Table 5). This is partially due to increased cropping intensity and partially because of adoption of high yielding cultivars. The three major staple crops in Nepal are rice, wheat and maize. A productivity comparison of these cereal crops shows that there is significant differences between irrigated and unirrigated conditions. Rice, a relatively water-intensive crop, has more than twice the productivity in the Mountain and Terai and more than thrice the productivity in the Hill (Table 6). Farmers can use other technologies such as high yielding varieties, fertilizers etc. with the regular irrigation, and contribute to higher productivity.

Table 6. Average farm productivity under irrigated and unirrigated condition (Qtl/farm)

\begin{tabular}{lllllll}
\hline Farm & Mountain & \multicolumn{3}{l}{ Hill } & & Tearai \\
\cline { 2 - 6 } productivity & Irrigated & Unirrigated & Irrigated & Unirrigated & Irrigated & Unirrigated \\
\hline Rice & $10.69(3.52)$ & $4.25(5.91)$ & $9.1(8)$ & $2.83(3.15)$ & $38.96(13)$ & $15.75(15.4)$ \\
Maize & $2.3(1.49)$ & $1.86(2.81)$ & $6.43(1.79)$ & $4.31(2.57)$ & $12.46(5.3)$ & $4.17(4.24)$ \\
Wheat & $2.93(1.90)$ & $1.94(2.36)$ & $3.92(1.59)$ & $2.3(1.39)$ & $9.42(4.31)$ & $3.59(4.52)$ \\
\hline
\end{tabular}

Source: Field Survey 2015. Values in parentheses are standard deviation

All respondents in Mountain and Terai, and $87.33 \%$ in the Hill region experienced increasing cost of water. On average, cost of water increased by $11.33 \%, 11.96 \%$ and 
$10.17 \%$ per annum in the Mountain, Hill and Terai, respectively; the highest increase being $20 \%$ and the lowest being 5\%. Agricultural water management has been an increasingly time consuming activities in overall livelihood maintenance. Reasons for the increase in waiting time to manage water (drawing water) in Mountain and Hill are the sharp reduction of water level in the creeks, and disappearing natural springs during winter and summer seasons.

Of the total, $96 \%, 98 \%$ and $95.33 \%$ of respondents are willing to pay a higher price for an additional unit of water for both agriculture and household management in the Mountain, Hill and Terai respectively. On average, respondents in the Mountain, Hill and Terai regions are willing to pay $78.24 \%, 62.24 \%$ and $76.33 \%$ more than the base period price of water (Table 7).

Table 7. WTP for additional water availability

\begin{tabular}{lllll}
\hline & Mountain & Hill & Terai & Total \\
\cline { 2 - 5 } WTP $(\%)$ & $78.24(30.63)$ & $88.53(43.78)$ & $62.24(44.65)$ & $76.33(41.55)$ \\
\hline
\end{tabular}

Source: Field Survey 2015. Values in parentheses are standard deviation

There is wide variation in water use among ground water users. Households who have an irrigation pump and deep boring/drilling facilities withdraw much more ground water than those with natural wells, cemented wells and shallow-tube wells. Pump holders achieve significantly higher water efficiency. From the focus group discussion and survey data we conclude that ground water extraction is increasing in aggregate but decreasing at the individual household level by small holders, ultra-marginal and 
landless. The declining water table in general, but especially during prolonged periods of drought, is inhibiting essential crop water withdrawals. The survey results indicate that only $20 \%$ of respondents in Terai region enjoy increasing amounts of ground water (with average increases of $11.5 \pm 4.57 \%$ ) whereas $80 \%$ respondents witnessed decreasing amounts of ground water (with average decreases $15.47 \pm 4.97 \%$ ).

Terai households who have irrigation pumps and/or who purchase water from pump owners consumed higher quality irrigation water. Farmers who use canal irrigation system also face problem such as silt, sand and other debris because of floods in their water sources (river/rivulet/creeks). Besides flooding, the practice of draining industrial waste and other chemicals directly to the riverine system without any treatment is severely affecting the surface water quality. All respondents in Hill and Terai regions experienced declining water levels in the creeks and tributaries. About $90 \%$ of respondents in the Mountain experienced decreased water level while $10 \%$ have experienced increased water level. Of the total (all regions), 96.97\% experienced decreasing water levels in their creeks. The spatial status of water level reduction in creeks/rivulets is presented in table 8 .

Table 8. Respondent's observation on \% water loss in creeks in the preveious 10-15 years

\begin{tabular}{lllll}
\hline$\%$ loss of water & Mountain & Hill & Terai & Total \\
\hline $50 \%$ & $89(59.33)$ & $4(2.67)$ & $11(7.33)$ & $104(23.11)$ \\
$75 \%$ & $54(36)$ & $113(75.33)$ & $109(72.67)$ & $276(61.33)$ \\
$100 \%$ & $7(4.66)$ & $33(22)$ & $30(20)$ & $70(15.55)$
\end{tabular}

Source: Field Survey 2015. Values in the parentheses are percentages 
Summer drought (March-June) and rainy season drought (July-October) are responsible for reducing farm productivity and hence farm revenue in both Hill and Terai regions. All respondents in Hill and Terai regions and $86.67 \%$ in the Mountain region have been experiencing increased days of drought in the past 5-7 years. The average increase in drought over the same period in Mountain, Hill and Terai are 9.03 \pm 4.64 , $9.86 \pm 3.02$ and $18.55 \pm 6.07$ days respectively. Only $13.33 \%$ of respondents in the Mountain region reported decreasing incidence of drought by an average of $0.81 \pm 2.22$ days. This decrease is because of restoration of broad- leaf forests through community afforestry programs and increased natural rainfall in the lower-belt of the Himalayas. Farmers explain that soil texture is important to withstand water stress conditions. Clay soil has relatively more water holding capacity than sandy and rocky soil. Cover cropping is another instrument to maintain top-soil moisture.

Some other important issues collected from focus group discussions regarding general perceptions, farmers' traditional knowledge and their expected solution to improve overall efficacy of water resource management are presented below (Box 1). This is the collective voice of more than a dozen respondents. 


\section{Box 1.}

Government should allocate significant amounts of financial capital to irrigation infrastructure development and management improvement in an institutional setting. Cessation of forest clearance, pollution control in water bodies and prudent withdrawal of groundwater are very important aspects of water resource system sustainability. Water management right transfer to Community Water User Group (CWUGs) is a step towards raising stakeholder's ownership and vesting common property resource management approach which is deemed to be more effective and sustainable. Field study reveals that about $10-12 \%$ agricultural production, and 20$25 \%$ conveyance efficiency can be increased just from periodical rehabilitation of neglected irrigation systems, mostly before the onset of rainy season. Small scale water storage ${ }^{22}$ can be instrumental in sustaining the water drought but remunerative in small scale vegetable production. Improving marketing management facilities would motivate farmers to value water and address the issue of integrating agriculture and water management interventions in order to derive full benefits from investments in irrigation. Irrigation systems are showing good results at the field level in terms of increasing agricultural productivity, improving water use efficiency and enabling water users to manage irrigation systems. Cropping intensities have increased from an average of 146 to $210 \%$ and yields of major staples namely rice, wheat and maize have increased, respectively, by $72.5 \%, 62 \%$ and $68 \%$ compared to $10-12$ years ago.

The Morangkhola Irrigation System (one of the study units in the Mountain region) is found having improved institutional capacity for agricultural and household water management. Planning, monitoring and inter-sectoral allocation of water resources have contributed to higher productivity in agriculture and improved environmental health (family health and surrounding environment).

Source: FGD, 2015. Six male and seven female participants

\footnotetext{
${ }^{22}$ Plastic pond, mud pond, roof water tap etc
} 


\subsection{Factors Affecting Water Use Efficiency}

The results of the ordinary least square analysis of factors affecting water use efficiency in the three ecological regions of Nepal are presented here. Various socioeconomic and spatial parameters are effective in explaining overall agronomic efficiency mostly in the same direction (positive) but in varied magnitude (Table 9). However some variables had surprising effects. The age variable was not significant but technology is highly significant in all ecoregions. One would expect that experienced farmers would be more effective in saving water. Local knowledge based technology such as plastic sheet cover over the porous and sandy soil, narrow-width cemented canal (Fig 5) and rainwater trap in plastic pond (Fig 6) in Hill and Mountain regions have proved effective. These practices are hardly seen in the Terai. Frenken and Faurès (1997) recommend increasing the effective use of rainfall, stored water, and water of marginal quality in the developing world to improve water productivity and farm revenue. Most of the marginal and smallholders are unable to invest in water saving infrastructure. During field visit ,survey-taker observed one unlikely event in which a small group of richer farmers were withdrawing ground water but lacked sufficient skills and organization to reduce water lost from source to site, especially conveyance efficiency (Fig. 7). 
Table 9. Factor affecting water use efficiency in the Terai region

\begin{tabular}{lcccc}
\hline Variable & Parameter Estimate & Standard Error & t Value & Pr $>|t|$ \\
\hline Intercept & -88.59577 & 219.30700 & -0.40 & 0.6868 \\
Age & -5.90409 & 3.37156 & -1.75 & 0.0821 \\
Education & 59.16648 & 63.14083 & 0.94 & 0.3503 \\
Household Size & 35.56203 & 23.20655 & 1.53 & 0.1277 \\
Farm size & 7.54424 & 1.57362 & 4.79 & $<.0001$ \\
Distance to Water Source & 44.89354 & 26.36198 & 1.70 & $<.0001$ \\
Technology Adaptation & -177.18647 & 44.22671 & -4.01 & $<.0001$ \\
Access to Extension services & 230.84275 & 55.10602 & 4.19 & $<.0001$ \\
Access to Credit & 2.07893 & 53.18237 & 0.04 & $<.0001$ \\
Distance to Nearby Market & 24.36332 & 8.97703 & 2.71 & 0.0075 \\
R-Square 0.3925, Adj R-Sq & 0.3535 & & & \\
\hline Source: Fid Survey, & & & & \\
\hline
\end{tabular}

Source: Field Survey, 2015.

Educated people have access to knowledge regarding managing water efficiently as compared to illiterate people. Farm size is a decisive factor explaining farm water use efficiency in Terai and Mountain regions. However, farm size has a negative effect on water use efficiency improvement in the Hill region (Table 10). One obvious reason for this effect, based on focus group discussions, (FGD) is absentee landlords. Big parcels of land are segmented and rented out to several tenants in the Hill region for short periods (less than 5 years). In aggregate, the farm size variable is highly significant in all regions. 
Distance between water sources to fields is another factor explaining water use efficiency in all ecological regions. This variable is mainly important to explain conveyance efficiency of irrigated water in the farm land in any cropping seasons. Increased conveyance efficiency would ultimately be reflected lower cost of water. The variable distance to water source is highly significant $(\mathrm{P}<.0001)$ in all ecological regions of the study area. A kilometer of reduced distant between source and site would contribute to increased overall water use efficiency in agriculture by $57.69 \%, 118.96 \%$ and $44.89 \%$ in Mountain, Hill and Terai respectively.

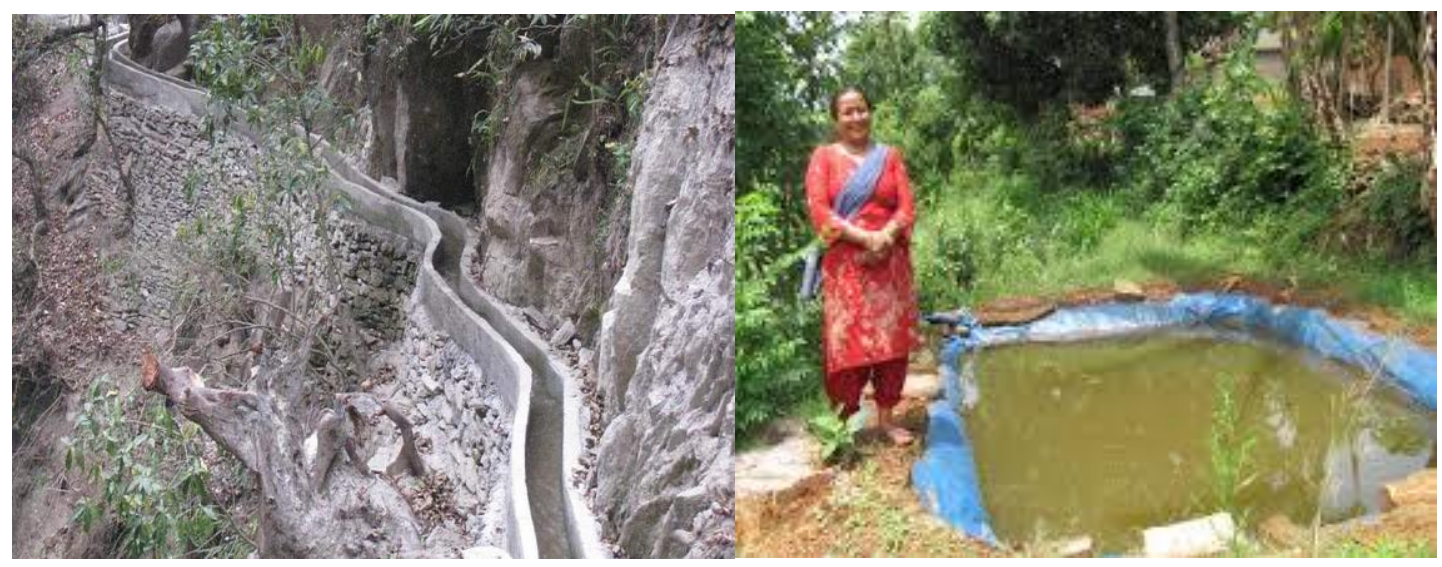

Figure 5. Cemented canal in Mountain plastic pond

Figure 6. Rainwater collection

Source: Field visit, 2015 


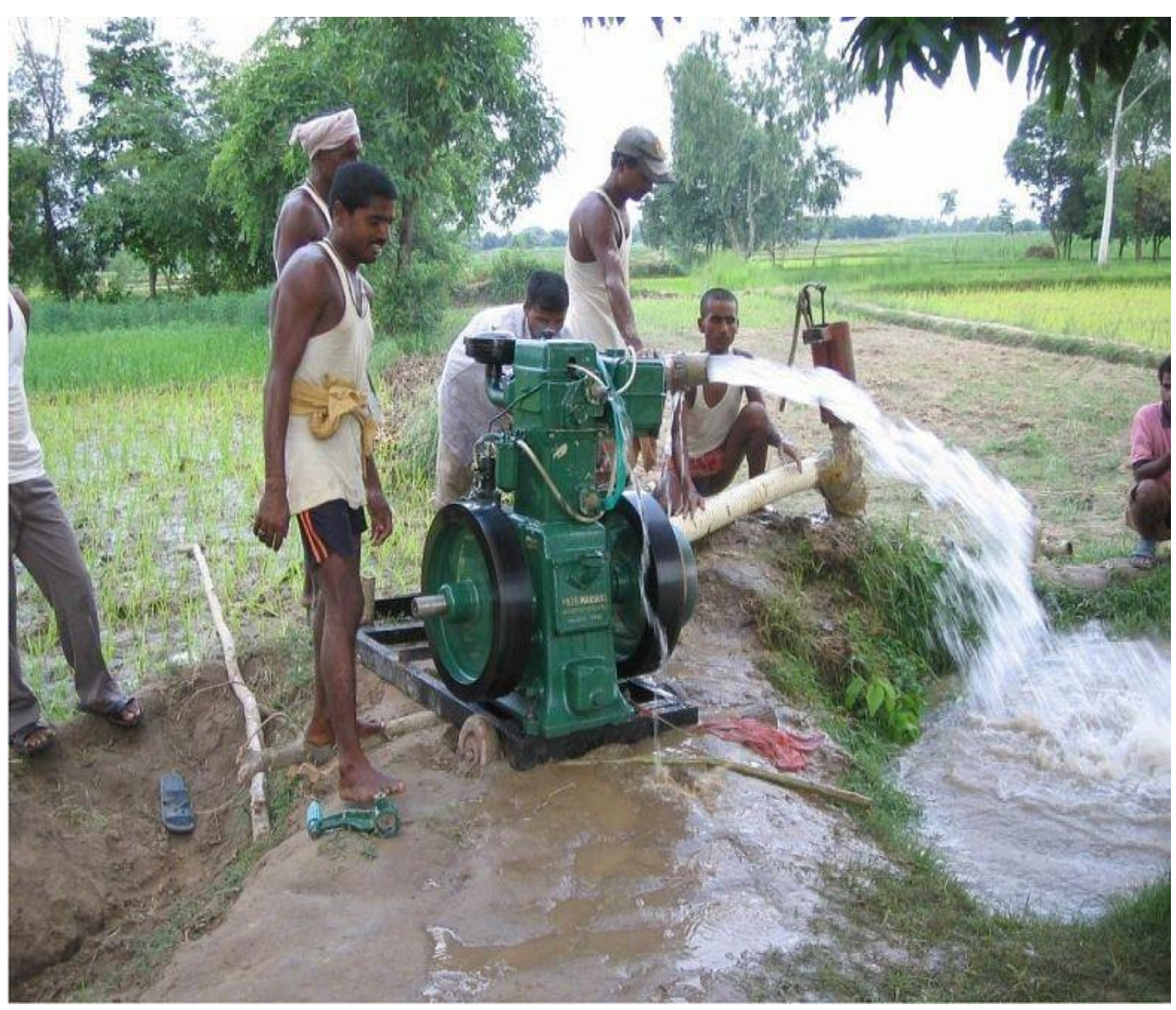

Figure 7. Artesian water extraction for agricultural purpose in Terai Source: Field visit, 2015

Government extension services are deemed very important for disseminating knowledge regarding agronomic practices, post-harvest and marketing management (MOAD, 2014). This variable is specifically important to marginal and smallholders in all regions. Demonstration projects are commonly used to motivate and engage farmers in agricultural business in all regions of Nepal. Access to extension services had a positive effect on water use efficiency. The extension service variable is significant in regressions for the Mountain (Table 11) and Terai regions (Table 9) but not in the Hill region. 
Table 10. Factor affecting water use efficiency in the Hill region

\begin{tabular}{lcccc}
\hline Variable & Parameter Estimate & Standard Error & $\mathrm{t}$ Value & Pr $>|\mathrm{t}|$ \\
\hline Intercept & 56.17510 & 78.27178 & 0.72 & 0.4741 \\
Age & 1.58101 & 1.46038 & 1.08 & 0.2808 \\
Education & 31.45141 & 26.37496 & 1.19 & 0.0351 \\
Household Size & -22.58596 & 10.77174 & -2.10 & 0.0378 \\
Farm size & -2.55958 & 2.37560 & -1.08 & 0.2831 \\
Distance to Water Source & 57.69934 & 35.06725 & 1.65 & $<.0001$ \\
Technology Adaptation & 49.13728 & 29.32421 & 1.68 & $<.0001$ \\
Access to Extension & 5.09905 & 39.34181 & 0.13 & 0.8971 \\
services & & & & \\
Access to Credit & 113.78436 & 27.17134 & 4.19 & $<.0001$ \\
Distance to Nearby Market & -2.11006 & 3.22252 & -0.65 & 0.5137 \\
R-Square 0.2057 Adj R-Sq & 0.1546 & & & \\
\hline Source: Field Survey, 2015 & & & & \\
\hline
\end{tabular}

Source: Field Survey, 2015

Farmers who have access to credit had higher water use efficiency. This is because it permits farmers to purchase water saving inputs such as polythene pipe, plastic sheets, cements etc. FGD revealed that residents believe that access to formal credit was more effective than informal credit. Effective monitoring and evaluation from formal credit institutions (banks, saving-credit cooperatives) are duly conducted while monitoring of informal sources of credit simply did not occur. This variable was found significant in all ecological regions to explain agricultural water use efficiency. 
Table 11. Factor affecting water use efficiency in the Mountain region

\begin{tabular}{lllll}
\hline Variable & Parameter Estimate & Standard Error & t Value & Pr $>|t|$ \\
\hline Intercept & 129.60990 & 219.79223 & 0.59 & 0.5563 \\
Age & 5.48730 & 2.99444 & 1.83 & 0.0690 \\
Education & 94.75619 & 72.55307 & 1.31 & 0.1937 \\
Household Size & -45.51454 & 26.86115 & -1.69 & 0.0924 \\
Farm size & 3.26609 & 4.24078 & 0.77 & 0.4425 \\
Distance to Water Source & 118.96612 & 46.33285 & 2.57 & $<.0001$ \\
Technology Adaptation & 259.99750 & 131.96039 & 1.97 & $<.0001$ \\
Access to Extension services & 579.41188 & 95.67467 & 6.06 & $<.0001$ \\
Access to Credit & 5.60388 & 43.97832 & 0.13 & $<.0001$ \\
Distance to Nearby Market & 7.18100 & 26.12581 & 0.27 & 0.7838 \\
R-Square 0.6032 Adj R-Sq & 0.5777 & & & \\
\hline Source: Fild Survey, & & & &
\end{tabular}

Source: Field Survey, 2015.

Comparison of the two regression models indicates that most of the socioeconomic variables have similar relationships to water use efficiency (Table 12). However, a few contrasts between the results from the two types of analysis were observed. Older people are less efficient in the Terai region but more efficient in the Hill and Mountain regions. Large farm size is associated with lower water use efficient in the Hill region in OLS but the Tobit regression shows that farm size is associated with inefficient water use in both Hill and Mountain. The reason could be due to scattered farming land and rugged topography that leads to high upfront costs in irrigation infrastructure. Educated farmers are effective in increasing agricultural water use 
efficiency in all regions except the Terai region (in the Tobit model). It could be because educated people in the Terai are less willing to work in farming and instead seek jobs in other sectors.

Table 12. Tobit regression on censored value of agronomic water use efficiency $\left(\mathrm{E}_{\mathrm{a}}\right)$ in the study regions

\begin{tabular}{|c|c|c|c|c|c|c|c|c|c|}
\hline \multirow[t]{2}{*}{ Variables } & \multicolumn{3}{|c|}{ Terai region } & \multicolumn{3}{|c|}{ Hill region } & \multicolumn{3}{|c|}{ Mountain region } \\
\hline & Coeff. & t-value & $P>|t|$ & Coeff. & $\begin{array}{l}\mathrm{t}- \\
\text { value }\end{array}$ & $P>|t|$ & Coeff. & t- value & $P>|t|$ \\
\hline Constant & $\begin{array}{l}-382.974 \\
(314.73)\end{array}$ & -1.22 & 0.226 & $\begin{array}{l}-40.3272 \\
(100.89)\end{array}$ & -0.40 & 0.690 & $\begin{array}{l}268.0305 \\
(281.806)\end{array}$ & 0.95 & 0.343 \\
\hline Age & $\begin{array}{l}-7.2337 \\
(4.6017)\end{array}$ & -1.57 & 0.118 & $\begin{array}{l}2.3964 \\
(1.899)\end{array}$ & 1.26 & 0.209 & $\begin{array}{l}7.0519 \\
(3.5988)\end{array}$ & 1.96 & 0.052 \\
\hline Education & $\begin{array}{l}69.4358 \\
(109.169)\end{array}$ & 0.64 & 0.526 & $\begin{array}{l}47.0978 \\
(33.849)\end{array}$ & 1.39 & 0.1666 & $\begin{array}{l}129.565 \\
(109.011)\end{array}$ & 1.19 & 0.237 \\
\hline $\begin{array}{l}\text { Household } \\
\text { Size }\end{array}$ & $\begin{array}{l}46.4526 \\
(32.92)\end{array}$ & 1.41 & 0.160 & $\begin{array}{l}-34.0974 \\
(14.171)\end{array}$ & -2.41 & 0.017 & $\begin{array}{l}-35.8557 \\
(32.8821)\end{array}$ & -1.09 & 0.277 \\
\hline Farm size & $\begin{array}{l}13.4935 \\
(2.2834)\end{array}$ & 5.91 & 0.000 & $\begin{array}{l}-1.0851 \\
(3.080)\end{array}$ & $-0.35-$ & 0.725 & $\begin{array}{l}-13.8373 \\
(8.586)\end{array}$ & -1.61 & 0.109 \\
\hline $\begin{array}{l}\text { Distance to } \\
\text { Water }\end{array}$ & $\begin{array}{l}95.5635 \\
(41.1115)\end{array}$ & 2.32 & 0.022 & $\begin{array}{l}15.3818 \\
(45.545)\end{array}$ & 0.34 & 0.736 & $\begin{array}{l}486.6818 \\
(115.331)\end{array}$ & 4.22 & 0.000 \\
\hline Source & & & & & & & & & \\
\hline $\begin{array}{l}\text { Technology } \\
\text { Adaptation }\end{array}$ & $\begin{array}{l}-151.5284 \\
(59.9134)\end{array}$ & 2.53 & .013 & $\begin{array}{l}25.0756 \\
(36.519)\end{array}$ & 0.69 & .493 & $\begin{array}{l}560.594 \\
(276.52)\end{array}$ & 2.03 & 0.045 \\
\hline $\begin{array}{l}\text { Access to } \\
\text { Extension } \\
\text { services }\end{array}$ & $\begin{array}{l}216.0964 \\
(79.5821)\end{array}$ & 2.72 & 0.007 & $\begin{array}{l}25.9188 \\
(49.306)\end{array}$ & 0.53 & 0.600 & $\begin{array}{l}468.6983 \\
(118.577)\end{array}$ & 3.95 & 0.000 \\
\hline $\begin{array}{l}\text { Access to } \\
\text { Credit }\end{array}$ & $\begin{array}{l}20.424 \\
(70.9686)\end{array}$ & 3.29 & 0.0081 & $\begin{array}{l}173.1618 \\
(36.499)\end{array}$ & 4.74 & 0.000 & $\begin{array}{l}53.2159 \\
(57.4773)\end{array}$ & 0.93 & 0.356 \\
\hline $\begin{array}{l}\text { Distance to } \\
\text { Market }\end{array}$ & $\begin{array}{l}22.6869 \\
(12.509)\end{array}$ & 1.81 & 0.072 & $\begin{array}{l}4.1385 \\
(4.193)\end{array}$ & 0.99 & 0.325 & $\begin{array}{l}28.2488 \\
(32.2494)\end{array}$ & 0.88 & 0.383 \\
\hline Prob. > chi2 & 0.0000 & & & 0.0000 & & & 0.000 & & \\
\hline Pseudo R2 & -7.3223 & & & -7.1823 & & & -7.705 & & \\
\hline $\log$ & 70.7014 & & & 23.1564 & & & 55.1609 & & \\
\hline
\end{tabular}

Likelihood

Source: Field survey, 2015. Value in the parenthesis indicates standard error (SE) 


\section{Essay Sumary and Policy Recommendations}

This study assesses the conveyance, economic and agronomic efficiency of water, and factor affecting aggregate water use efficiency in each ecological region. There is a significant difference in cropping intensity between irrigated and unirrigated farm conditions. Average cropping intensity in the study area is $242 \%$ and $150 \%$ in irrigated and unirrigated conditions. Farmers in the Mountain region were relatively more efficient in reducing water loss between water source and fields than farmers in the Hill and Terai region. Farms operating under irrigated conditions in Hill and Terai have more than twice the gross margin compared to unirrigated conditions. This is partially due to increased cropping intensity and partially due to adoption of high yielding cultivars. Agricultural water management have been an increasingly time consuming activity in all study regions. Reasons for increasing wait time to manage water in Mountain and Hill are due to sharp reductions in water in winter and summer seasons in the creeks, and disappearing natural springs which were lifelines for agricultural and household water supply.

Results of both regression models show that elderly respondents are not efficient at water management in the Terai region but are efficient in the Hill and Mountain region. Large farm size is found less efficient in the Hill region. Technology such as plastic sheet covers over the porous and sandy soil, narrow-width cemented canal and rain-water trap in plastic ponds in Hill and Mountain regions have proven effective. Only a few rich (large farm) farmers who have installed ground water pumping facilities are able to 
reduce on-farm seepage. Government extension service is found significant in Mountain and Terai but not in Hill. Access to formal credit which helps to purchase better farm inputs and other necessary on-farm activities was found significant in all ecological regions to explain agricultural water use efficiency.

This part of study draws attention to investments in small scale water infrastructure to reduce water loss such as conveyance water loss between sources and sites. These findings are similar to the recent study (World Bank, 2016) in High and Dry: Climate Change, Water and the Economy report. Message of the community from focus group discussion was: strengthened institutional capacity of community for agricultural and household water management such as planning, monitoring and inter-sectoral allocation of water resources have contributed to higher productivity in agriculture and improved environmental health (family health and surrounding environment).

What farmers believe and survey results supports is that there are two possible strategies for increasing water use efficiency-supply side and demand side management. On the supply side, water resource infrastructure such as small scale dams, cemented irrigation canals, permanent structures in water source locations and water storage facilities. The demand side approach is more behavioral such as consciousness to reduce water seepage, evaporation and overuse. Selection of high-value-low-volume crops (which consume less water) to increase the marketable yield of farming system is a commonly suggested alternative way to increase water productivity. Mulching keeps top soil wet for a longer period; reducing tillage or zero tillage reduces evaporation, and 
maximizing the dependence on rainfall by minimizing water loss such as runoff, drainage, seepage, evaporation and weed control, for example, are some of the feasible yet behavioral approaches to increasing overall efficiency of water use in agricultural.

\section{References}

Barker, R., Dawe, D. and Inocencio, A. 2003. Economics of water productivity in managing water for agriculture. In J.W. Kijne, D. Molden \& R. Barker, eds. Forthcoming. Water productivity in agriculture: limits and opportunities for improvement. Comprehensive Assessment of Water Management in Agriculture Series, No. 1. Wallingford, UK, CABI Publishing.

Cook, Simon; Gichuki, Francis and Turral, Hugh. 2006. Agricultural water productivity: estimation at plot, farm and basin scale. Colombo, Sri Lanka: International Water Management Institute (IWMI). Basin Focal Project Working Paper No. 2.

Eriksson, M.; Xu, J.; Shrestha, A.B.; Vaidya, R. A.; Nepal, S. and Sandstörm, K. 2009. The Changing Himalayas: Impact of climate change on water resources and livelihoods in the greater Himalayas. Perspectives on water and climate change adaptation. ICIMOD, Kathmandu.

FAO. 2012. Irrigation in Southern and Eastern Asia in Figures AQUASTAT Survey - 2011. FAO Water Reports 37. Rome: Food and Agriculture Organization of the United Nations.

Frenken, Karen and Jean-Marc Faurès. 1997. Irrigation potential in Africa: A basin approach. Land and Water Development Division of FAO. ISBN 92-5-103966-6 Available at: http://www.fao.org/docrep/W4347E/w4347e02.htm\#acknowledgements 
Grassini, P., Thorburn, J., Burr, C. \& Cassman, K.G. 2011. Field Crops Res. Field Crops Res. 120: 142-150.

Griffin, Ronald C. 2016. Water Resource Economics: The Analysis of Scarcity, Policies, and Projects, Second edition, MIT Press.

Grismer, M. E. 2002. Regional cotton lint yield, ETc and water value in Arizona and California. Agric. Water Manage. 54: 227-242.

Hillel, D., 1997. Small-Scale Irrigation for Arid Zones: Principles and Options. FAO Development Series 2, Rome.

Immerzeel, W.W.; Beek, L. P. H. and Bierkens, M. F. P. 2010. Climate Change Will Affect the Asian Water Towers. Science, 328, 1382 (2010);DOI: 10.1126/science. 1183188.

IPCC (2007a) Climate Change 2007: The Physical Science Basis. Contribution of Working Group I to the Fourth Assessment Report of the Intergovernmental Panel on Climate Change [Solomon, S; Qin, D; Manning, M; Chen, Z; Marquis, M; Averyt, KB; Tignor, M; Miller, HL (eds)]. Cambridge and New York: Cambridge University Press.

IPCC. 2007. Contribution of Working Group II to the Forth Assessment Report of the Intergovernmental Panel on Climate Change. Accessed on 20 November at 2013 http://www.ipcc.ch/publications_and_data/ar4/wg2/en/contents.html

Irmak, S., L. O. Odhimbo, and William L. Kranz. 2011. Irrigation Efficiency and Uniformity, and Crop Water Use Efficiency. University of Nebraska- Lincoln Extension. EC732. Access on: http://ianrpubs.unl.edu/live/ec732/build/ec732.pdf 
Kijne, Jacob W. 2003. Unlocking the water potential of agriculture. Land and Water Development Division of the Food and Agriculture Organization of the United Nations (FAO). Available at:

http://www.fao.org/docrep/006/y4525e/y4525e04.htm\#TopOfPage

Kijne, J.W., Tuong, T.P., Bennett, J., Bouman, B., Oweis, T., 2003b. Ensuring food security via improvement in crop water productivity. In: Challenge Program on Water and Food: Background Papers to the Full Proposal. The Challenge Program on Water and Food Consortium, Colombo, Sri Lanka.

MOAD, 2014. Ministry of Agriculture and Development. Annual Progress Report. Kathmandu, Nepal.

Martin, Edward C. 2006. Determining the Amount of irrigation water Applied to a Field. Arizona Water series No. 29. Available at:

https://extension.arizona.edu/sites/extension.arizona.edu/files/pubs/az1157.pdf

Molden, D., Sakthivadivel, R. \& Habib, Z. 2001. Basin-level use and productivity of water: examples from South Asia. Research Report 49. IWMI, Colombo.

Ostrom, Elinor. 2007. A diagnostic approach for going beyond panaceas. Proc. Natl. Acad. Sci. , USA, 104 ( 39).

Panta, Krishna Prasad. 2012. The Journal of Agriculture and Environment. 13: 919.

Peng, S., Laza, R.C., Khush, G.S., Sanico, A.L., Visperas, R.M., Garcias, F.V., 1998. Transpiration efficiencies of indica and improved tropical japonica rice grown under irrigated conditions. Euphytica 103, 103-108. 
Perry, Chris; Steduto, Pasquale; Allen, Richard G.; Burt, Charles M. 2009. Increasing productivity in irrigated agriculture: Agronomic constraints and hydrological realities. In: Agricultural water management, 96 (2009): 1517-1524.

Rogers, P., de Silva, R. \& Bhatia, R. 2002. Water is an economic good: how to use prices to promote equity, efficiency, and sustainability. Water Policy, 4: 1 - 17.

Rosul, Golam. 2014. Food, water, and energy security in South Asia: A nexus perspective from the Hindu Kush Himalayan region. Environmental Science and Policy. 39:35-48.

Sadras, Victor O.; Patricio Grassini and Pasquale Steduto. 2007. Status of water use efficiency of main crops.

Access

at:http://www.fao.org/fileadmin/templates/solaw/files/thematic_reports/TR_07_web.pdf

Savva, Andreas and Karen Franken. 2002. Irrigation Development: a Multifaceted Process. FAO-SAFR, Irrigation Manual Module 1. Access at:ftp://ftp.fao.org/agl/aglw/docs/irrigman1.pdf (Nov 17, 2014).

Sharma, E.; Bhuchar, S.; Xing, M. A. and Kothyari, B. P. 2007. Land use change and its impact on hydro-ecological linkages in Himalayan watersheds. Tropical Ecology, 48(2): 151-161.

Sharma, K. P., 1993. Role of Meltwater in Major River Systems of Nepal. In Young, G.J. (ed) International Symposium on Snow and Glacier Hydrology, Kathmandu, International Association of Hydrological Sciences, Publication No. 218, pp 113 - 122. Wallingford (UK): IAHS. 
Siddique, K.H.M., Tennant, D., Perry, M.W., Belford, R.K., 1990. Water use and water use efficiency of old and modern cultivars in a Mediterranean-type environment. Aus. J. Agric. Res., 41: 431-447.

Singh, P. and S. K. Jain. 2002. Snow and glacier melt in the Satluj River at Bhakra Dam in the western Himalayan region. Hydrol. Sci. J. 47(1): 93-106.

Tao, F; Yokozawa, M. and Hayashi, Lin E., 2005. A perspective on water resources in China: interactions between climate change and soil degradation. Climatic Change, 68: 169-197.

Tarar, R. N., 1982. Water resources investigation in Pakistan with the help of Landsat imagery snow surveys, 1975-1978. In: Hydrological aspects of alpine and high mountain areas. Proceedings of the Exeter Symposium, July 1992, IAHS Publication No 138, 177-190. Wallingford: IAHS.

Thapa, Sridhar and Joshi, Ganesh Raj, 2010, A Ricardian analysis of the climate change impact on Nepalese agriculture. Available at MPRA: http://mpra.ub.unimuenchen.de/29785/ accessed on: April 13, 2013.

Tuong, T. P., 1999. Productive water use in rice production: opportunities and limitations. J. Crop Prod. 2, 241-264.

UNEP. 2001. Nepal: State of the Environment 2001. United Nations Environment Program and International Centre for Integrated Mountain Development, Kathmandu, Nepal.

Wang, Li-fang and Zhou-ping Shangguan. 2015. Water-use efficiency of dryland wheat in response to mulching and tillage practices on the Loess Plateau. Scientific Reports, 5:12225. doi: 10.1038/srep12225 
WECS. 2011. National water plan. Kathmandu: His Majesty's Government of Nepal, Water and Energy Commission Secretariat (WECS). Kathmandu, Nepal.

World Bank, 2016. High and Dry: Climate Change, Water, and the Economy. Access at: http://www.worldbank.org/en/topic/water/publication/high-and-dry-climatechange-water-and-the-economy on May 6, 2016.

Xu, J.; Shrestha, A. and Eriksson, M. 2009. Climate change and its impacts on glaciers and water resource management in the Himalayan Region. Assessment of Snow, Glacier and Water Resources in Asia. International Hydrological Programme of UNESCO and Hydrology and Water Resources Programme of WMO.

Young Robert A. and John B. Loomis.2014.Determining the Economic Value of Water: Concepts and Method. RFP Press.

Zhang, S., Kang, S.Z., Liu, X. M. and Xiong, Y. Z. 1995. A study on the variation laws of field phreatic water evaporation and its calculation method. Water Resources and Hydraulic Engineering, 6, 9-15.

Zwart, Sander J. and Wim G. M. Bastiaanssen. 2004. Review of measured crop water productivity values for irrigated wheat, rice, cotton and maize. Agricultural Water Management, 69: 115-133. 


\section{Summary, Conclusions and Policy Implications}

A face to face survey of 450 randomly selected households in the Koshi river basin of Nepal was conducted. The survey focused on farming system efficiency with an emphasis on irrigation water management practices, climate change impacts on agricultural water resources irrigation water use efficiency, and current adaptation practicesin different ecological regions of Nepal.

Essay-one estimates the Technical, allocative and cost efficiency and factors responsible to explain technical efficiency in farming community in upriver and downriver region. Data Envelopment Analysis technique was used to estimate various types of efficiencies. Tobit regression was applied to determine factors affecting technical efficiency (TE) of smallholder farming practices. Mean constant returns to scale TEs are 0.59 and 0.75 in the upriver and downriver respectively. Mean variable returns to scale TEs are recorded as 0.63 and 0.75 in the upriver and downriver respectively. The median technical efficiency values were 0.606 and 0.756 in upriver and downriver respectively. Lower productivity of small scale farming units are due to inadequate water availability, lack of reliable inputs and poor market services. Males are positively contributing to improve TE in the upriver ecoregion but inefficient in the downriver ecoregion. Farm experience is not a significant factor. Education has a negative impact on efficiency in the downriver ecoregion while it is positive in the upriver ecoregion. More rural respondents were less technically efficient in both upriver and downriver regions. Shorter distances to water source, forest and market centers are significant factors explaining technical 
efficiency in both ecoregions. Access to farm credit and electricity are significant and positive factors explaining technical efficiency in both regions.

Essay-two examines the on-going consequences of climate change on water resource availability and how adaptation practices and strategies have developed in the study regions. Incidence of both drought and flooding are increasing in Nepal. A majority of the respondents reported increasing temperatures, more intense precipitation, and greater frequency of flooding than in the past. Prolonged drought followed by intense rain leading to flooding has led to a significant increase in sand deposition and water quality degradation. About two-thirds of small creeks and springs have disappeared and others will soon disappear if current trends continue. Both agricultural and household water procurement and management are consuming more time and resources. The survey indicates that only $46.01 \%$ of total water demand in the study area is fulfilled at present. Respondents in the Mountain, Hill and Terai regions are willing to pay $78.24 \%, 62.24 \%$ and $76.33 \%$ more than the baseline period price for water. All respondents in the Mountain region, $72 \%$ in Hill region and $85 \%$ in the Terai region prefer collective water management. Logistic regression analysis shows that farm income, market access, access to extension services, desire to emigrate, and distance from the market are statistically significant predictors of adaptive behavior in the Mountain region.

Essay-3 deals with conveyance, economic and agronomic efficiency of water used, and factors affecting aggregate water use efficiency in the study regions. Farmers in the Mountain region were found relatively more effective at reducing water loss (between 
source and site) than farmers in the Hill and Terai regions. Water use efficiency scores regressed on farm related socio-economic variables using two models- Ordinary Least Square and Tobit regression shows that farm size, distance to water source, government agricultural extension services and access to credit positively affect water use efficiency in all regions. Farm size had a negative effect on water use efficiency improvement in the Hill region but a positive effect in the Mountain and Terai regions. Distance to a water source is highly significant in all ecological regions of the study area. Government extension services had a positive effect on water use efficiency and was significant in the Mountain and Terai regions but not in the Hill region. Access to credit at financial institutions made a significant contribution to agricultural water use efficiency in all ecological regions.

The results of Technical Efficiency reveal that farmers could potentially reduce their inputs for cereal crop production on average by $41 \%$ and $34 \%$ if they had access to credit, marketing management and water saving technologies. Farmers operating below 0.5 TE would benefit from upgraded farm management practice via extension services, and by learning resource rationing practices from peer members who are operating above the median TE in the regions. Reliable water source revitalization via green infrastructure development (forestation, wetland protection) and community based source water management should be considered in future research.

Collective management of water resources in bysmall groups is a potential adaptation approach for source water protection and effective water allocation in the 
community. Policies could increase incomes by discouraging cereal cultivation in the Mountain and Hills given current and future levels of water resource availability. Water supply management (small scale dams in creeks and rivulets, cemented canal) can increase and stabilize the water supply for agricultural activities and should be supported by policy. Extension services should be extended to rural region with sufficient staffs. The Koshi river basin, this region alone could add as much as $46,958 \mathrm{~km}^{2}$ irrigated farming if better water management and necessary infrastructure was provided. Based on the productivity difference between adaptive and non-adaptive farmers, it is estimated that more reliable water supplies could result in a $10 \%$ increment in the livestock (herd size) and an increase in farm outputs of about 11,700 mt of cereal crops (rice, maize, wheat, and barley), 20,000 mt of vegetables and livestock, which together would be worth about NRs. 20-25 millions to the local economy.

Farmers in the Mountain region are relatively more effective in reducing water loss between water sources and fields than farmers in the Hill and Terai regions. Because large farm size is found less efficient in the Hill region, extension service should be focused on small holders. Technology such as plastic sheet covers over the porous and sandy soil; narrow-width cemented canals and rain-water traps in plastic ponds in Hill and Mountain regions have proven to be effective means of conserving water. Access to formal credit helps farmers invest in small scale water infrastructure projects designed to reduce water losses such as conveyance water loss. Mulching practices, reducing heavy tillage and better weed control can reduce evaporation and minimize water loss due to runoff, drainage, seepage, and evaporation. 


\section{VITA}

Krishna Lal Poudel is a Nepalese citizen and attended schools and colleges in Nepal until he got his B.Sc. and M. Sc. degree in Agricultural Sciences. He worked for Water Management Study Program about 3 years until he completed Master degree. Then He worked in Federation of Nepalese Chambers of Commerce and Industry (FNCCI), a private sector's apex organization as an Agribusiness and Marketing Analyst in order to implement USAID-Nepal funded private sector agribusiness development in Nepal. At the same period, he worked as a Assistant Professor in the Himalayan College of Agricultural Science and Technology (HICAST), a vibrant private academic institution in agricultural research and development in Nepal. He then went on to pursue a $\mathrm{PhD}$ degree in Agricultural and Applied Economics at the University of Missouri (MU) which he completed in 2017. He is interested in applied research related to issues of agricultural water resources management in different ecological settings. 